\title{
OPEVNĚNÍ NOVÝ HRAD (ZÁMEČEK) U STRÁŽE (OKRES TACHOV). ZEMĚPANSKÁ STRÁŽNICE A CELNICE Z PŘELOMU 12. A 13. STOLETÍ
}

\author{
PETR SOKOL - FILIP KASL
}

\begin{abstract}
Abstrakt: Mezi Stráži a Přimdou na Tachovsku se nachází mohutné zemní opevnění, jehož pưvod a účel nebyly dosud vysvětleny. Opevnění čtvercového půdorysu $82 \times 83$ m tvořené vnitřním valem, př́kopem ve tvaru pismene $V$ a vnějším valem je situované v rovinatém terénu. Relikty byly dosud interpretovány jako pozdně středověký dvůr či raně středověké hradiště. Situaci komplikují nálezy raně středověké keramiky $i$ výrazný, velmi dobře dochovaný tvar reliktu atypický pro uvedené druhy lokalit. Terénni průzkum i rešerše historických map ukázaly úzkou a stěžejní vazbu na jednu z hlavních větví zemské stezky (později tzv. Norimberské). Nové poznatky prinesla i aplikace detektorové prospekce a archeologická sondáž. Obsahem př́spěvku jsou informace o průzkumu objektu, datování a interpretace středověké lokality jako strážnicel celnice z přelomu 12. a 13. století.
\end{abstract}

Klíčová slova: středověk - hranice - celnice - strážnice-zemská stezka - Norimberská cesta.

The Nový hrad (Zámeček) fortification near Stráž (Tachov district). A guardhouse and custom-house from the late 12th/early 13th century

Abstract: A mighty fortification the origin and purpose of which are yet to be explained is located between Stráž and Přimda in the Tachov region. The fortification on a square ground plan of $82 \times 83 \mathrm{~m}$ consisted of an internal rampart, a $V$-shaped ditch and an external rampart and is situated in a flat terrain. Its remains have been interpreted as a late medieval manor or an early medieval hillfort. The situation is complicated by the finds of early medieval pottery and the distinct, well-preserved shape of the fortification, unusual for the mentioned types of sites. Terrain research and comparison with historical maps showed a close and important link with one of the main branches of the land route (later called the Nuremberg route). New findings were also yielded by metal detecting and archaeological probing. The key part of this contribution is information about research into the feature, its dating and the interpretation of this medieval site as a guardhouse/custom-house from the late 12th/early 13th century.

Key words: Middle Ages - border-custom-house - guardhouse-land route - Nuremberg route.

Západně od Stráže $(2,3 \mathrm{~km})$ a jihovýchodně od hradu Přimda $(5,4 \mathrm{~km})$ v okrese Tachov je v lukách v neobvyklé poloze dochováno výrazné a mohutné zemní opevnění (obr. 1). Dosavadní interpretace jsou značně nejisté a rozdílné. V souvislosti s výzkumem hradu Přimdy (SokolPrekop 2013; Sokol 2014; 2014a; 2015; 2015a; 2016) a jeho okolí (Sokol 2011; 2016) přistoupili autoři tohoto př́spěvku k výzkumu i této sporné lokality s cílem vyjasnit účel a původ atypického opevnění. Výzkum byl prováděn v letech 2016-2019 plzeňským pracovištěm Národního památkového ústavu.

\section{Popis lokality}

Opevnění představuje téměř pravidelný čtvercový útvar o vnějších rozměrech $82 \times 83 \mathrm{~m}$ $(Z-V \times S-J)$. Vnější linii opevnění tvoří val na jižní a východní straně dochovaný do výšky až téměř $2 \mathrm{~m}$, na zbylých stranách je znatelně menší. Někde je před tímto vnějším valem shledáván ještě vnější úzký a mělký př́íkop o šířce do $2 \mathrm{~m}$ a hloubce do $0,5 \mathrm{~m}$ (Hajšman 2001, 50). Střední linii představuje příkop s profilem písmene $\mathrm{V}$, hluboký dnes od koruny vnějšího valu 1-3 $\mathrm{m}$, od koruny vnitřního valu pak 4,5-6m (obr. 2). Šiřka př́íkopu mezi korunami vnějšího a vnitřního valu se pohybuje mezi 6 a $9 \mathrm{~m}$. Vnitřní prvek opevnění tvoří mohutný val převyšující vnitřní plochu areálu o 2-2,5 m, s korunou širokou 1-3 m (obr. 3). Volný plochý vnitřní prostor má rozměry $27,6 \times 27 \mathrm{~m}(\mathrm{Z}-\mathrm{V} \times \mathrm{S}-\mathrm{J})$ a jeho rozloha činí $745 \mathrm{~m}^{2}$ (obr. 4).

Vstup do objektu se nacházel na východní straně, kde je vnitřní val přerušen. Na koruně valu jsou patrné „zářezy“, zejména na západní straně, částečně i na straně severní a jižní (obr. 14 a 15). Jejich původ není jasný, nejspíše jde však až o pozdější zásahy spojené se starším 


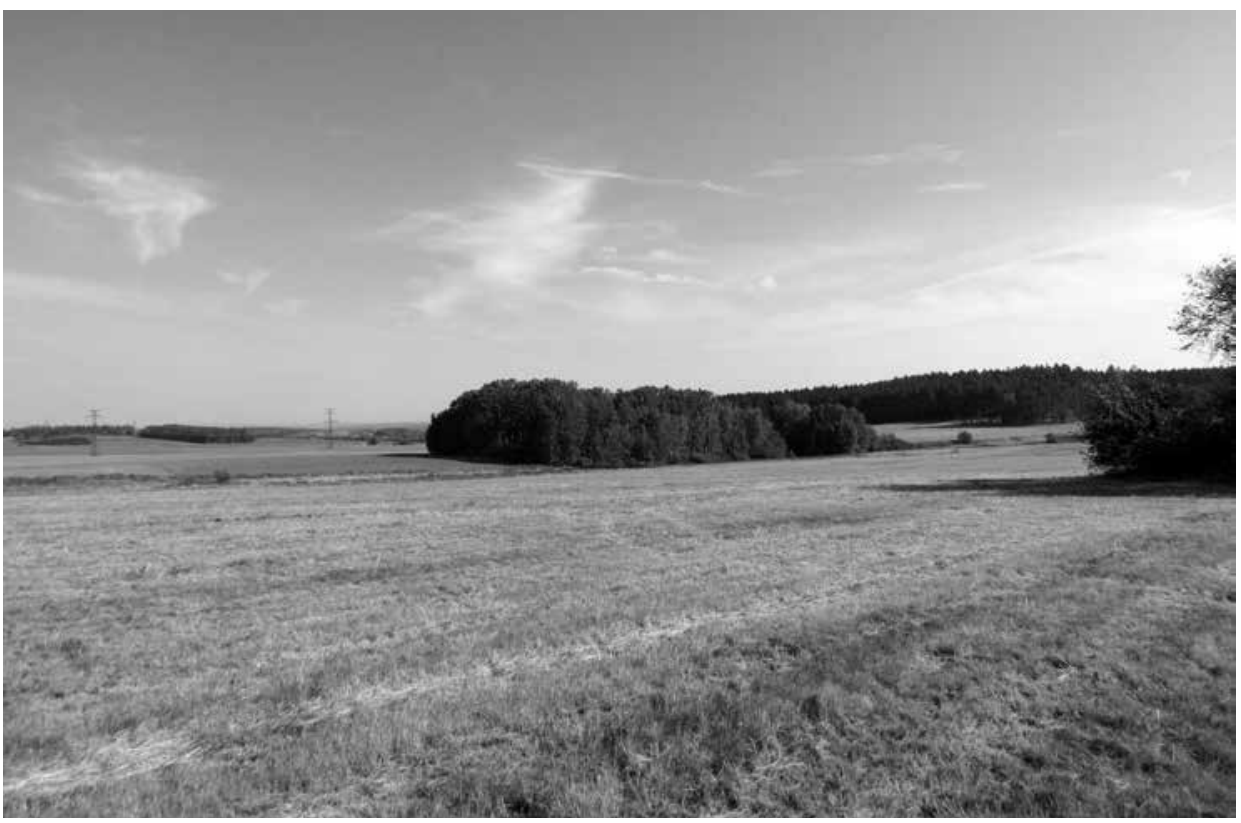

Obr. 1. Zámeček, k. ú. Stráž, okr. Tachov. Opevnění v lesíku uprostř̌ed snímku, pohled od jihozápadu. Foto P. Sokol, 2016. Abb. 1. Schlössl, Katastergebiet Stráž, Bezirk Tachov. In dem Wäldchen in der Mitte der Aufnahme die Befestigung, Blick von Südwesten. Foto P. Sokol, 2016.

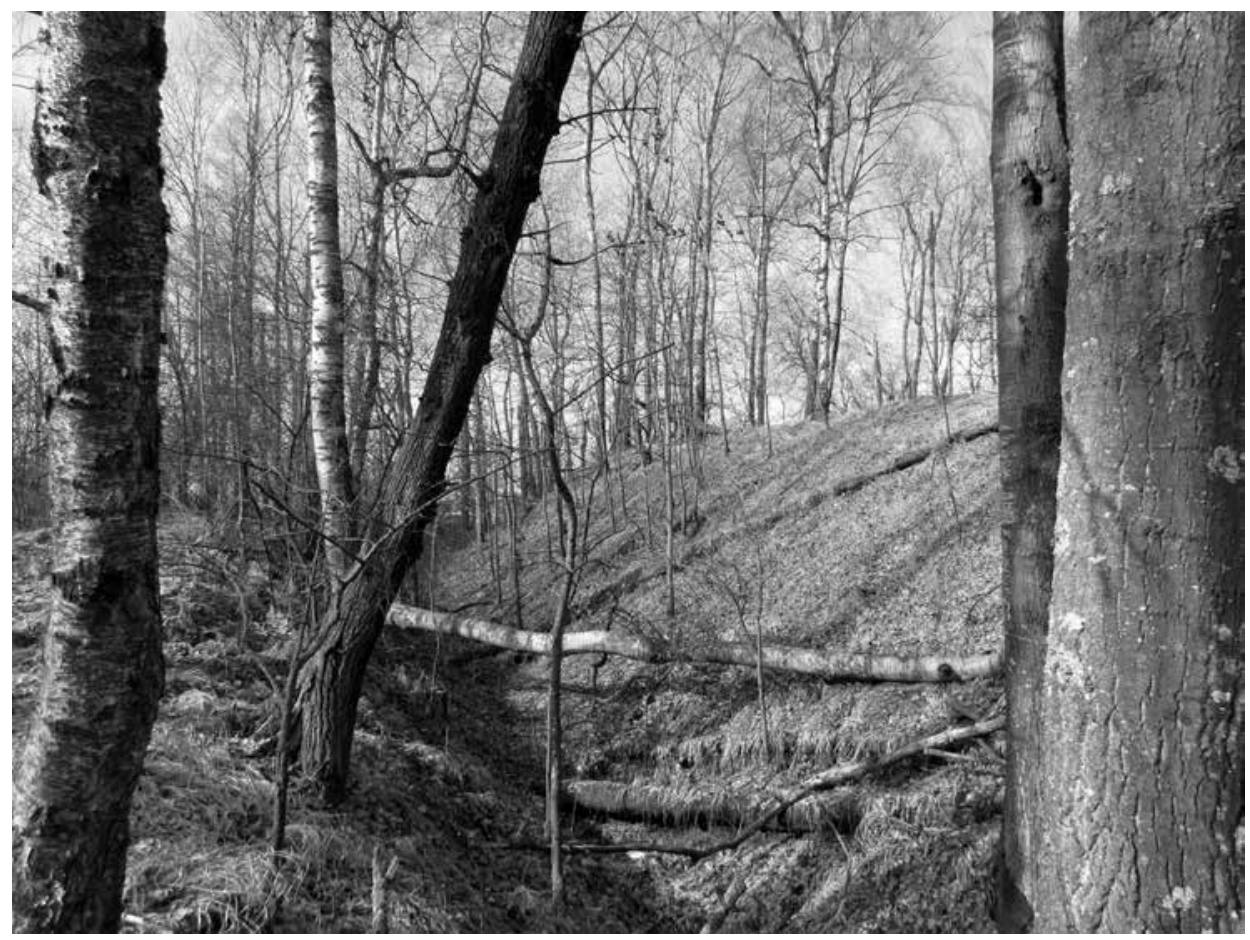

Obr. 2. Zámeček, k. ú. Stráž. Jižní strana opevnění. Foto F. Kasl, 2019.

Abb. 2. Schlössl, Katastergebiet Stráž. Südseite der Befestigung. Foto F. Kasl, 2019. 


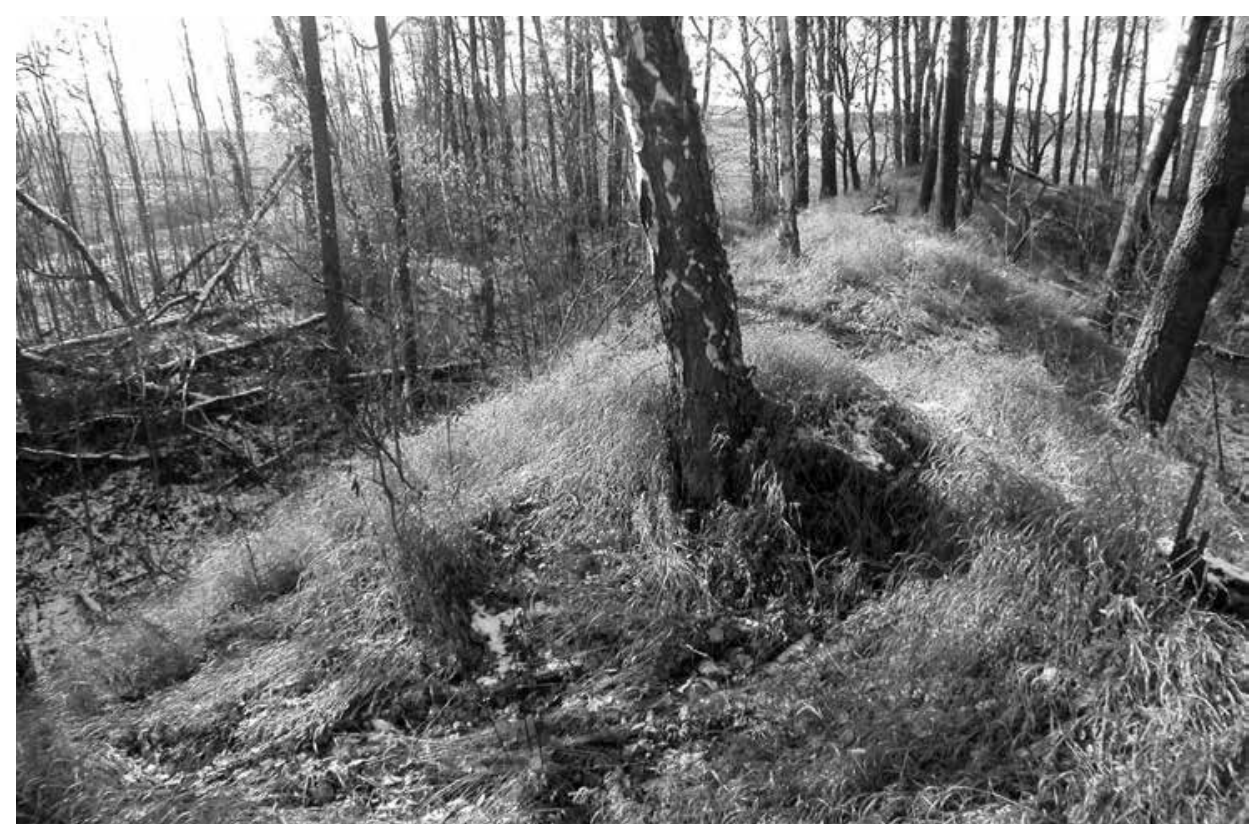

Obr. 3. Zámeček, k. ú. Stráž. Jižní vnitřní val od východu. Foto P. Sokol, 2006.

Abb. 3. Schlössl, Katastergebiet Stráž. Südlicher Innenwall von Osten. Foto P. Sokol, 2006.

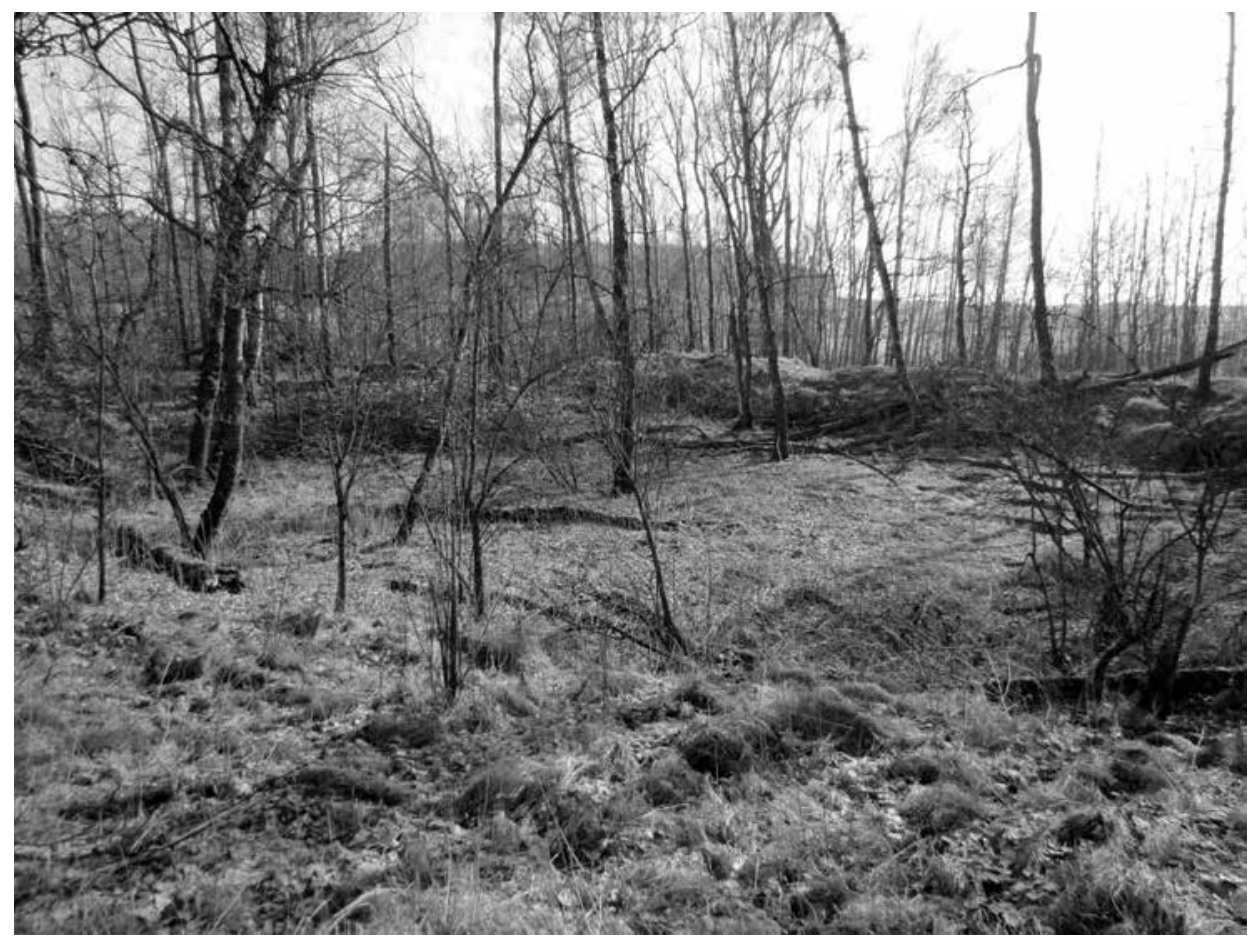

Obr. 4. Zámeček, k. ú. Stráž. Vnitřní plocha objektu od severozápadu. Foto F. Kasl, 2019.

Abb. 4. Schlössl, Katastergebiet Stráž. Innenfläche des Objektes von Nordwesten. Foto F. Kasl, 2019. 
výzkumem nebo s obdobím druhé světové války (pozice pro ležící střelce), které bylo na lokalitě doloženo nálezem nábojnice.

Opevnění se dnes nachází v lesnatém ostrůvku obklopeném poli a pastvinami, v nadmořské výšce $517 \mathrm{~m}$ (vnitřní plocha). Areál vznikl na mírné vyvýšenině vymezené na východě a na jihu hranami zamokřené nivy drobných vodotečí, které se zde stékají (obr. 5). Na západní a severní straně navazuje okolní terén plynuleji, což se mohlo negativně projevit v dochování vnějšího valu v důsledku zemědělských činností. Dnes se okraje obdělávané půdy nachází v několikametrovém odstupu od vnějšího valu. Při východní straně opevnění je menší rybník, zachycený na všech dostupných historických mapách počínaje josefským mapováním. Ze severovýchodního rohu opevnění pokračuje směrem k rybníku příkop (propust) naznačující propojení rybníku $\mathrm{s}$ prríkopem opevnění.

Objekt se tedy nachází spíše v rovinatém terénu. Vzhledem k blízkosti hřebene táhnoucího se ve směru jihozápad-severovýchod a oddělujícího polohu opevnění od Stráže nebylo situování do výšinné polohy evidentně určujícím kritériem pro výběr polohy opevnění.

Granitové a zejména rohovcové podloží v nejbližším okolí lokality obsahuje želené zrudnění srovnatelné s brdskými silicity (Lachman 2018). Jak dokládají charakteristické stopy v terénu v prostoru hřbetu mezi opevněním a Stráží (obr. 9), přípovrchová montánní činnost zde v blíže neurčené době probíhala, její souvislost s existencí opevnění však nelze prokázat.

Dosavadních nálezů z lokality není známo mnoho. V časech A. Sedláčka bylo v opevnění kopáno (pozůstatkem těchto výkopů mohou být zmiňované „zářezy“ na koruně valu), on sám však nálezy, pomineme-li zjištění stop ohně a charakteru valu, neuvádí. Jediné dosud známé nálezy tak zmiňuje Z. Procházka, který v roce 1981 získal z narušené kulturní vrstvy vnitřní plochy zlomky keramiky datované do přelomu 12. a 13. století (Procházka 1984, 118). Jiné nálezy

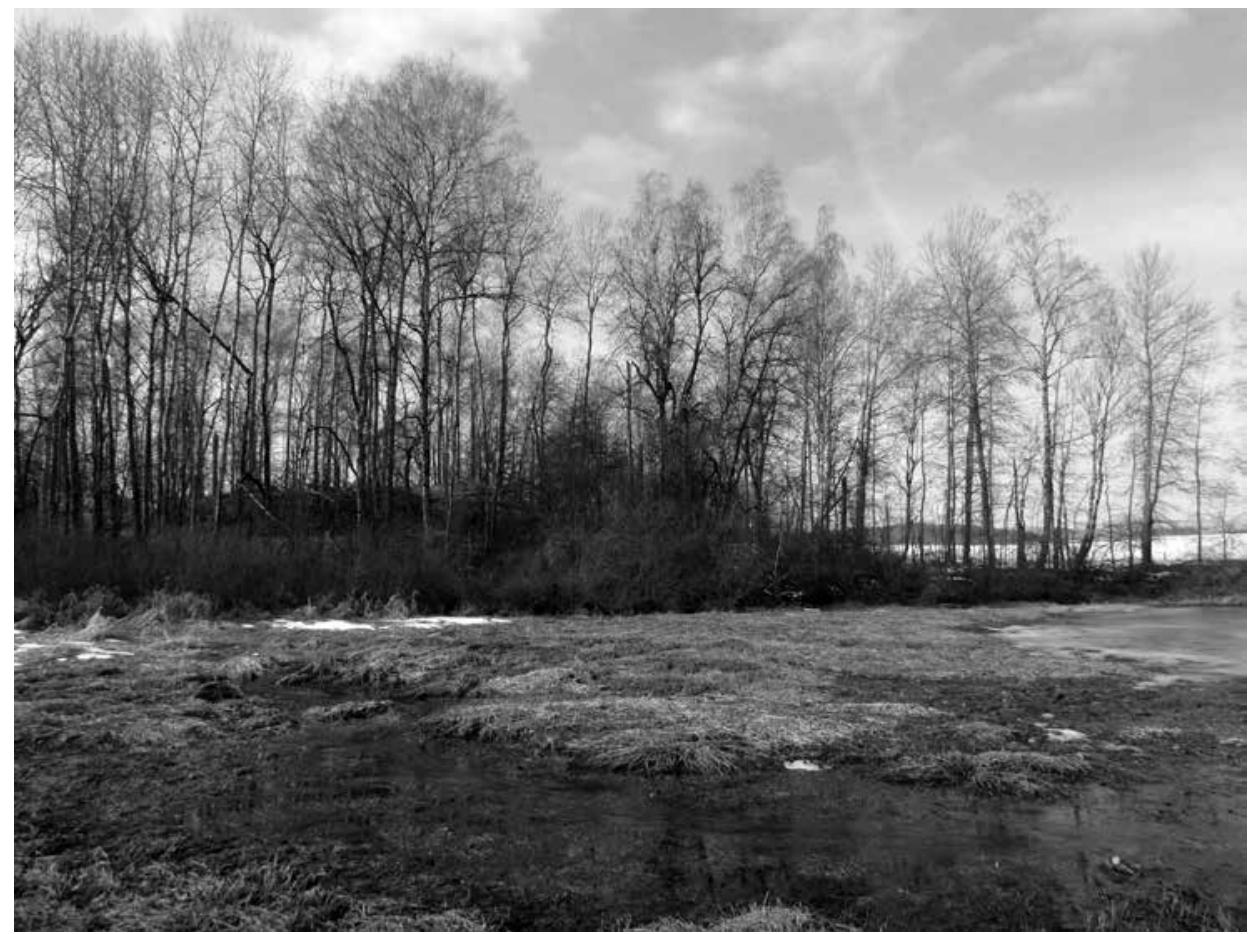

Obr. 5. Zámeček, k. ú. Stráž. Opevnění od východu. Foto F. Kasl, 2019.

Abb. 5. Schlössl, Katastergebiet Stráž. Befestigung von Osten. Foto F. Kasl, 2019. 


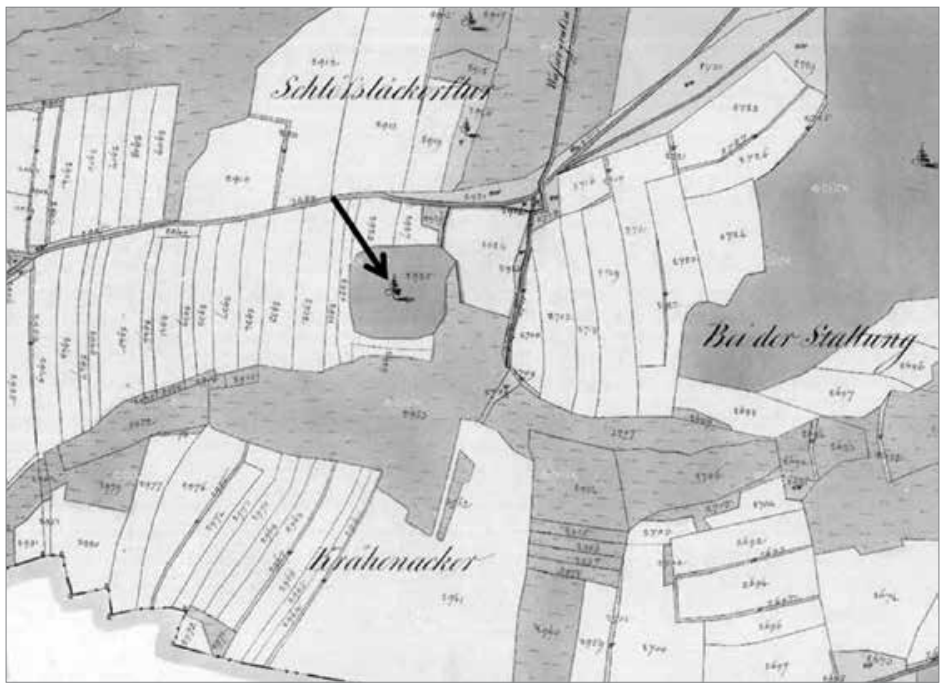

Obr. 6. Zámeček, k. ú. Stráž. Výřez z císařského otisku mapy stabilního katastru (Archivní mapy). Šipka označuje polohu Zámečku, severně od něj průběh dnes již zaniklé cesty. Při pravém okraji dvě z vodních nádržek s hrázemi. Upravil P. Sokol.

Abb. 6. Schlössl, Katastergebiet Stráž. Ausschnitt aus einem Kartenabdruck des Stabilen Katasters (Archivkarte). Der Pfeil kennzeichnet die Lage des Schlössls, nördlich von ihm der Verlauf des heute bereits verschwundenen Weges. Am rechten Rand zwei kleine Teiche mit Dämmen. Bearbeitet von P. Sokol.

zřejmě představuje střepový materiál řazený $\mathrm{k}$ povrchovému průzkumu provedenému v roce 1982 D. Baštovou a Z. Procházkou (Nováček 1993). Opět z narušené kulturní vrstvy vnitřní plochy bylo získáno 31 zlomků keramiky, z toho šest tuhových, datovaných do 13. století, s možným přesahem do 12. století. ${ }^{1}$ Sběry tehdy proběhly i na okolních polích (obr. 19). Z míst zhruba $600 \mathrm{~m}$ severně od opevnění byly získány tři atypické zlomky keramiky archaického charakteru, datované opět nejspíše do 13. století. Z pole 400-500 m západně od opevnění pochází soubor keramických zlomků řazených do VS $2-\mathrm{N}$ 1, stejně je datováno i několik střepů nalezených 600 m jihozápadně od opevnění (Nováček 1993).

Z množství nedávných i současných menších vkopů je evidentní, že lokalita neunikla pozornosti nelegálního detektoringu.

\section{Historie lokality}

K samotnému opevnění nejsou dosud známy údaje z písemných pramenů. Pracovat tak lze pouze s informacemi týkajícími se nedaleké Stráže, popřípadě dalších sídelních útvarů v okolí, a s údaji získanými z historických map.

Stráž je prvně zmiňována roku 1331, kdy obdržela od panovníka některá městská privilegia (Baštář 1973, 1). Funkci opěrného bodu při česko-bavorské hranici však mohla plnit již v 12. století, nejpozději v první polovině 13. století, jak dokládá portál kostela sv. Václava (Procházka 1995, 71; Kuča 2008, 85-87). Stráž byla střediskem svobodných sedláků - tzv. přimdských Chodů, jejichž stěžejní činností byla ostraha hranice. Okolní př́ihraniční oblast byla spravována purkrabím 5 km vzdáleného zeměpanského hradu Přimda (Procházka 1995, 71; Kuča 2008, 87).

Jedním z pomístních názvů vztahujících se k lokalitě je Neuhaus. Označení „Zum Neuen Haus“" pro okolní pozemky je uváděno poprvé k roku 1596 (Sedláček 1998, 110). Název lokality

1 Revizi původního datování provedla $H$. Hrubá. 
Neuhaus se poprvé objevil na mapě stabilního katastru z roku 1838, a to severozápadně od opevnění.

Opevnění samotné se však mnohem častěji označovalo jako Schlössl - Hrádek, Zámeček (Sedláček 1998, 110). Toto jméno je zaneseno na 2. vojenském mapování, použito bylo i při 3. vojenském mapování a v obměněné podobě je uvedeno i na císařském otisku mapy stabilního katastru pro pozemky v okolí opevnění jako Schlössläckerflur (obr. 6). V písemných pramenech se název „U Zámečku“ a „Nad Zámečkem“ objevuje již v roce 1580 pro pole v okolí blízkých Malých Dvorců (Procházka-Úlovec 1991, 308). Z. Procházka přidává k uvedeným ještě další užívaný název - Žižkovy šance (Procházka 1984, 118).

\section{Dosavadní interpretace}

Do české odborné literatury lokalitu uvedl A. Sedláček, který podal i její popis. Opevnění podle Sedláčka tvoří hliněné valy, ve kterých nebyl při kopání nacházen žádný kámen. Na vnitřní ploše byly v zemi patrné stopy ohně (Sedláček 1998, 110). Rybník mohl podle Sedláčka vzniknout v souvislosti s odtěžením zeminy na valy, vzájemné propojení umožňovalo napouštět prŕíkop vodou. A. Sedláček považoval za dobu vzniku opevnění polovinu 15. století. Bez uvedení konkrétní funkce uvedl, že objekt byl zřejmě vystavěn zástavními držiteli Přimdy, nejspíše Janem ze Švamberka okolo roku 1456 (Sedláček 1998, 110). Tyto údaje převzal i R. Turek $(1970,13)$.

Sedláček však nebyl první, kdo Zámeček v literatuře zmínil. Tím byl zřejmě J. Köferl, který dal lokalitu do souvislosti s německou kolonizací probíhající zde od konce 12. do 14. století. Na lokalitě „,neue Hause (Schlössl)“ měl sídlit úředník dohlížející na německé kolonizátory a jejich okolní sídla (Köferl 1890, 32, 472). Stráž samotnou považoval Köferl za území a sídlo slovanské (Köferl 1890, 464).

Rovněž J. Baštář v roce 1973 v návaznosti na J. Köferla považoval Neuhaus za sídlo úředníka spravujícího tamější hospodářství a chránícího pozemky a úrodu německých usedlíkủ bydlících v okolních vsích a majících v dědičném nájmu strážské pozemky. Baštář ztotožnil Neuhaus s Neuhäuslem, prodávaným v roce 1601 (Baštář 1973, 4). Podle této interpretace by tak objekt vznikl před rokem 1601 .

Z. Procházka klade vznik do období konce 12. a počátku 13. století na základě nálezů keramiky z kulturní vrstvy vnitřní plochy (Procházka 1984, 118). Absence kamenné destrukce budov i hradby a charakter opevnění považoval za znaky ukazující na nevelké raně středověké hradiště. Společně s J. Úlovcem považoval opevnění za hrad přechodného typu (Procházka-Úlovec 1991, 297), bez ohledu na situování v rovině pod návrším, u dnes již zaniklé cesty, později uvažoval o refugiálním účelu pro obyvatelstvo okolních chodských vsí (Procházka 1992; 1995, 69).

Zřejmě nejdůsledněji a nejpodrobněji se lokalitě věnoval J. Hajšman (2001). Podal podrobný popis opevnění, přičemž evidoval zářezy na koruně západního valu, které zřejmě správně považuje za stopy výkopů zmiňovaných Sedláčkem (Hajšman 2001, 49-50). J. Hajšman odmítá vodní charakter př́ikopu v důsledku propojení s rybníkem (Hajšman 2001, 51), uvažuje o možném zaniklém osídlení v okolí s odkazem na nedaleký zaniklý kostel sv. Štěpána (první zmínka z roku 1523; Procházka 1995, 34), na tvar katastru a na nedaleké zaniklé rybníčky (Hajšman 2001, 52). Založení Zámečku považuje z důvodů náročnosti za čin z vůle panovníka (tamtéž). J. Hajšman si povšiml i možné vazby na cestu s tím, že opevnění mohlo představovat opěrný bod spojený s chodskou ostrahou hranic (tamtéž). Své předchozí úvahy však následně odmítl zpochybněním vzniku ve 12. století pro charakter odlišný od známých opevnění z té doby - hradiště (poloha, pravidelnost, jednoprostorové uspořádání, malé rozměry) a pro absenci analogií (Hajšman 2001, 52-53). Současně zavrhl i refugiální účel objektu z důvodů jeho umístění a nedostatečně velkých rozměrů (Hajšman 2001, 52).

J. Hajšman došel na základě formálních znaků k závěru, že opevnění Zámeček lze nejspíše řadit mezi laténské čtyřúhelníkové areály (Hajšman 2001, 53). Spáleništní vrstvu zmiňovanou Sedláčkem považuje za pohřbený půdní horizont $\mathrm{z}$ doby před výstavbou valů, jaký se daří na 
laténských čtyřúhelníkových valech identifikovat (Waldhauser 1992, 551). Mladší nálezy pak podle Hajšmana dokládají druhotné využití jako záchytný bod během kolonizace (Hajšman 2001, 54).

Pochybnosti o vzniku Zámečku na přelomu 12. a 13. století opatrně vyjádřil T. Durdík $\mathrm{z}$ důvodů malých rozměrů a nápadné pravidelnosti opevnění a naznačil možnou nesoučasnost nálezů a opevnění (Durdík 2000, 390; 2005, 452). Pokud by nálezy středověké keramiky souvisely s opevněním, pak by šlo podle T. Durdíka o výjimečný objekt „z mimořádně málo známého a velmi závažného procesu kvalitativní změny od raně středověkých hradišt’ k vrcholně středověkým hradům" (Durdík 2000, 391). T. Durdík však upozornil na zpochybňující fakt - vnitřní lehké konstrukce, které lze v objektu předpokládat, se nijak nezapojovaly do obrany objektu, která by tak spočívala pouze na obvodovém terénním opevnění. Hypotézu J. Hajšmana vidí T. Durdík jako problematickou $(2002,71-72)$ s tím, že v př́ípadě Zámečku nic jiného než formální morfologické znaky tento směr uvažování nepodporuje, a s odkazem na nejednoznačnou interpretaci některých lokalit, které jsou za laténské čtyřúhelníkové areály považovány na základě opět jen formálních morfologických znaků.

Nejasnosti v interpretacích Zámečku nevyřešili ani autoři Encyklopedie hradišst v Čechách. Převzali datování opevnění Z. Procházky do konce 12. a počátku 13. století s uvedením, že do míst opevnění A. Sedláček omylem situoval jinde se nacházející Nový hrad užívaný v 15. a 16. století (Čtverák a kol. 2003, 299). Ztotožnění Neuhausu se Schlösslem (Schlössl Neuhaus) najdeme však již u Köferla (1890, 473).

Naposledy se k lokalitě Zámeček vyjádřil K. Kuča, který počítá s datováním podle Z. Procházky a uvažuje o přechodném typu mezi hradištěm a hradem, ovšem pozoruhodným malými rozměry, dále o útočištné funkci, ale i o mladší vojenské fortifikaci (Kuča 2008, 85). Opevnění dává do možné souvislosti s ostrahou hranic prostřednictvím strážských Chodů (Kuča 2008, 87).

\section{Zemská stezka}

Tvar katastru Stráže obsahuje ve své západní části výraznou anomálii. Katastrální území zde vybíhá k západu v podobě delšího výběžku, který prochází mezi katastry Malých Dvorců a Kundratic a svým koncem navazuje na k. ú. Přimda (obr. 7). Obě sídla (Přimda i Stráž) byla původně zeměpanská, obě měla stěžejní funkci na trase zemské stezky. Směru výběžku odpovídají jak dochované úvozy ve východním svahu pod Přimdou (obr. 8), tak i směr úvozů na hřbetu západně od Stráže (obr. 9 a 10). Osu výběžku představuje cesta doložená na historických mapách (obr. 11), dochovaná fyzicky ještě v období po polovině 20. století a spojující zmíněné úvozy (např. Letecká mapa Čech a Moravy z roku 1953). Její směr dále k východu drží i orientace náměstí ve Stráži, kterým tato cesta procházela. Cesta vedla v těsné blízkosti opevnění Zámeček podél jeho severní strany a přecházela zde potoční údolí po hrázi přilehlého rybníka (obr. 6). Samotný Zámeček je vůči výběžku katastru umístěn jako zátka uzavírající jeho ústí (obr. 7). Dnes již po této cestě nejsou v terénu stopy. Cesta držela trasu historické zemské stezky, tzv. přimdské větve Norimberské cesty, o níž je první zmínka k roku 1124 (Široký-Nováček 1998, 64). Výběžek katastrálního území je tedy zřejmě pozůstatkem historické situace a úzce s existencí cesty souvisí (snad je důsledkem zájmu o kontrolu zemské stezky ze strany panovníka tak, aby celý úsek spadal do jeho majetku a cesta $v$ tomto strategicky důležitém úseku byla zajištěna co nejlépe).

Vzhledem k významu zemské stezky pro Zámeček je třeba se tomuto jejímu úseku věnovat podrobněji. U Norimberské cesty se zřejmě již od počátku formovaly dvě větve. Jednu zajištoval hrad Přimda, tato cesta směřovala dále na Stráž a Kladruby, od 14. století na Stříbro. Druhou, severněji vedenou větev zajišt'oval hrad v Tachově, odkud cesta vedla opět na Kladruby, nebo také severněji k Teplé, Manětínu a na Prahu (Roubík 1938, 12).

Postup kolonizace k hranici na Tachovsku se zintenzivnil po 11. století, kdy se česká kníŽata začala častěji zúčastňovat říšských sněmů (Žemlička 1997, 55). Z opačné strany byl postup do pomezního hvozdu zřejmě rychlejší a v tomto kontextu je třeba vnímat Kosmovu zmínku 


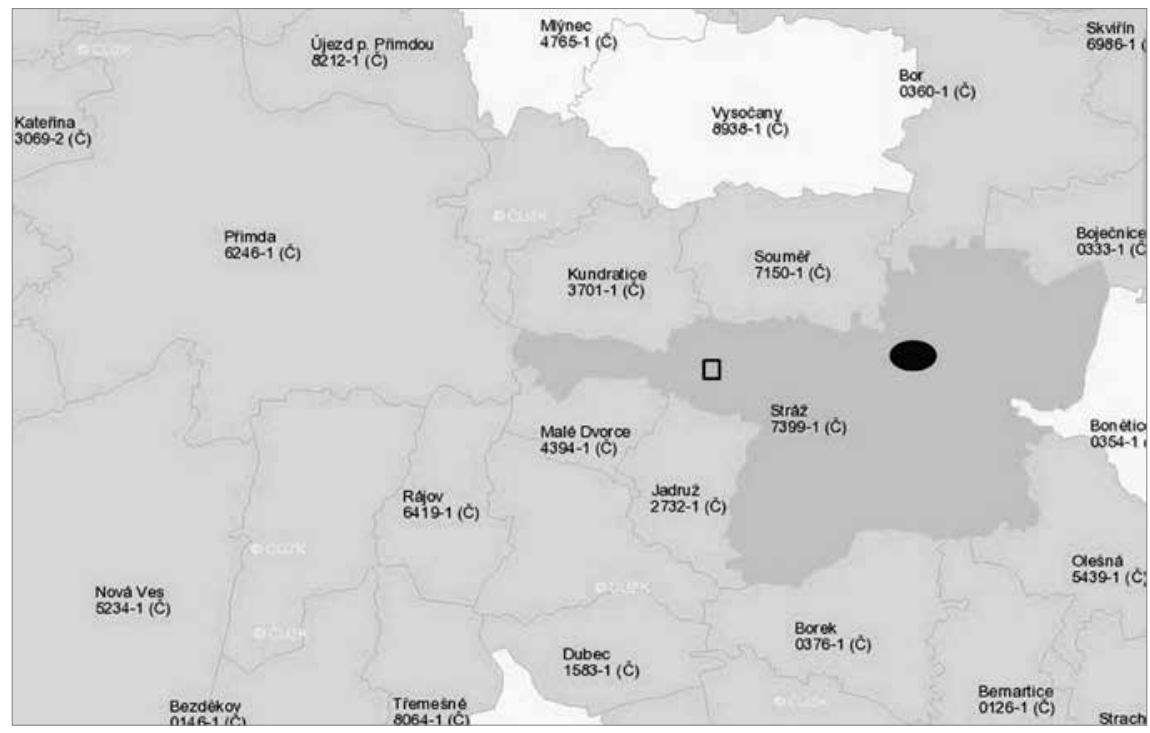

Obr. 7. Zámeček, k. ú. Stráž. Katastrální území Stráže (Archivní mapy) s vyznačenou polohou města (elipsa při pravém okraji) a objektem Zámečku (čtvereček). Upravil P. Sokol.

Abb. 7. Schlössl, Katastergebiet Stráž. Katastergebiet Stráž (Archivkarte) mit gekennzeichneter Lage der Stadt (Ellipse am rechten Rand) und des Objektes Schlössl (Quadrat). Bearbeitet von P. Sokol.

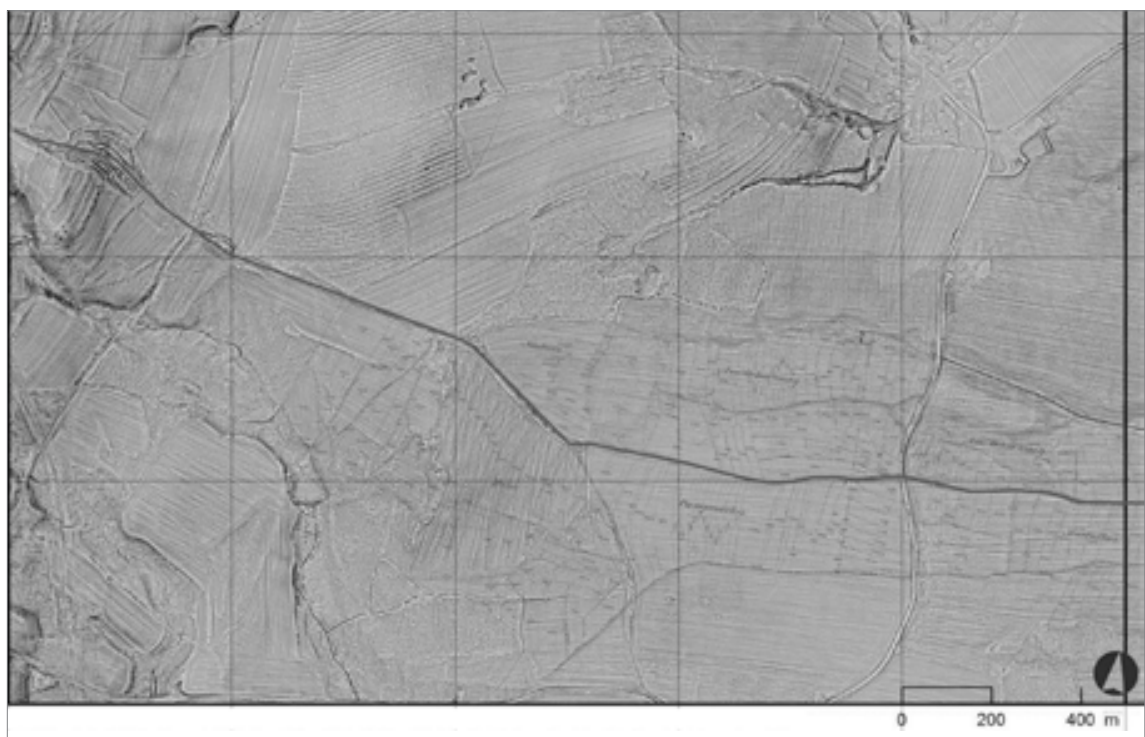

Obr. 8. Zámeček, k. ú. Stráž. Digitální model terénu prostoru západního konce k. ú. Stráž z dat leteckého laserového skenování po robustní filtraci (ČÚZK Praha) s podkladem mapy stabilního katastru. Zdůrazněna trasa cesty ve směru Z-V. U levého horního rohu svazek úvozů ve svahu stoupajícím k sedlu pod hradem Přimda. Zhotovil O. Malina, upravil P. Sokol, 2016.

Abb. 8. Schlössl, Katastergebiet Stráž. Digitales Geländemodell des Raumes am westlichen Ende des Katastergebietes Stráž anhand der Daten eines luftgestützten Laserscannings nach robuster Filterung (Tschechisches Amt für Landesvermessung und Kataster) und einer Kartenunterlage des Stabilen Katasters. Hervorgehobene Wegtrasse in N-O-Richtung. In der linken oberen Ecke eine Konzentration von Hohlwegen im zum Bergsattel unterhalb von Burg Přimda aufsteigenden Hang. Erstellt von O. Malina, bearbeitet von P. Sokol, 2016. 


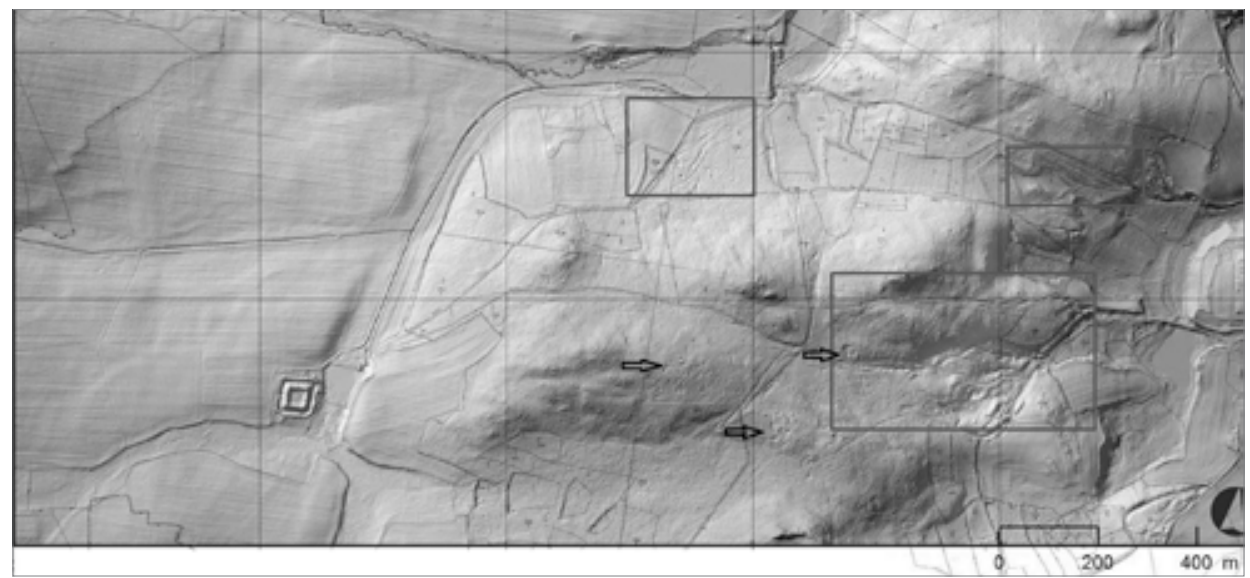

Obr. 9. Zámeček, k. ú. Stráž. Digitální model terénu prostoru mezi Zámečkem a Stráží z dat leteckého laserového skenování po robustní filtraci (ČÚZK Praha) s vyznačením úseků dochovaných úvozů (polygony) v trase zemské stezky mezi Přimdou a Stráží. Šipky ukazují místa přípovrchové těžby. Zhotovil O. Malina, upravil P. Sokol, 2016.

Abb. 9. Schlössl, Katastergebiet Stráž. Digitales Geländemodell des Raumes zwischen dem Schlössl und Stráž anhand der Daten eines luftgestützten Laserscannings nach robuster Filterung (Tschechisches Amt für Landesvermessung und Kataster) mit Kennzeichnung der Abschnitte der erhaltenen Hohlwege (Polygone) auf der Trasse des Landespfades zwischen Přimda und Stráž. Die Pfeile zeigen die Stellen eines oberflächennahen Bergbaus. Erstellt von O. Malina, bearbeitet von P. Sokol, 2016.

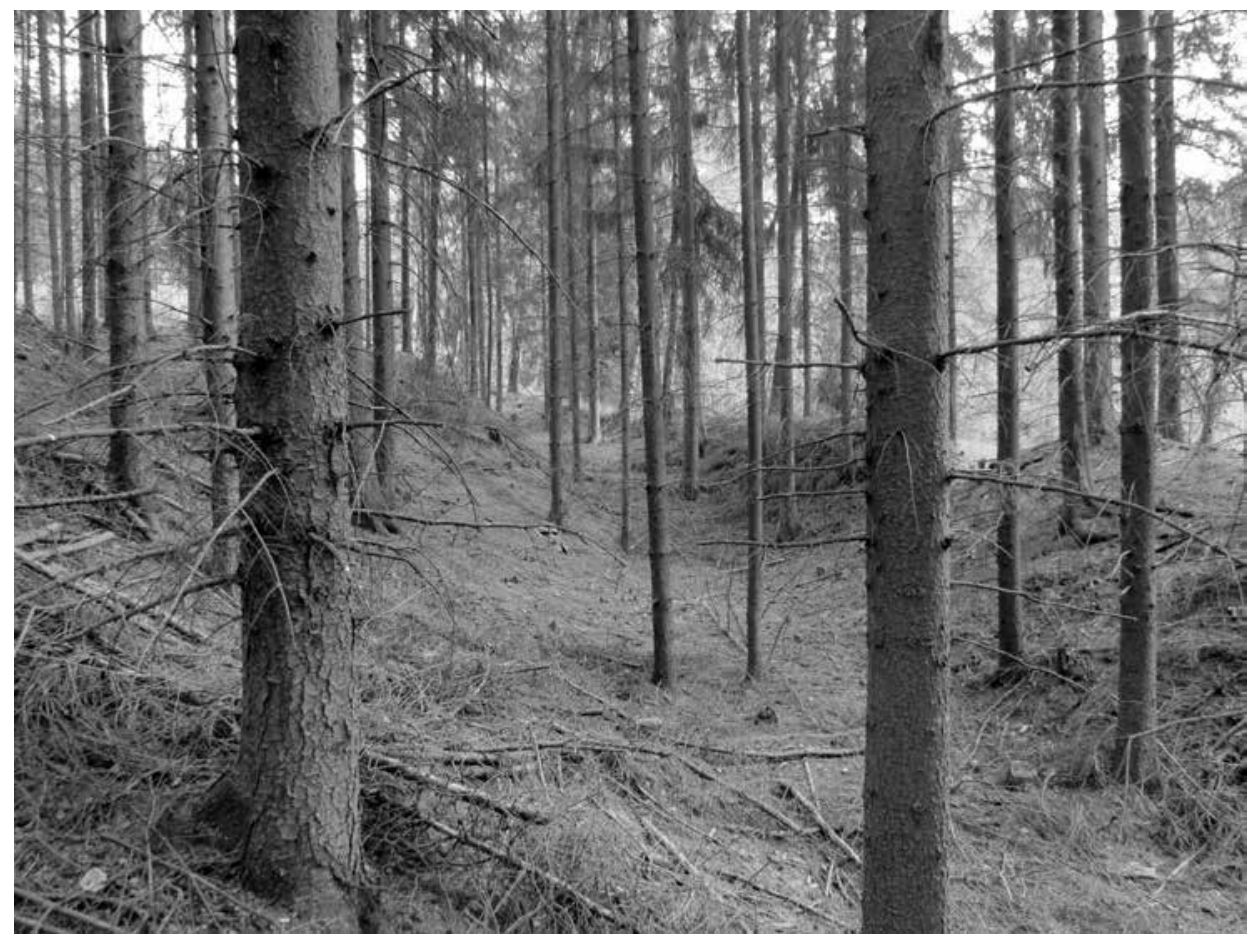

Obr. 10. Zámeček, k. ú. Stráž. Úvozy západně od Stráže v trase zemské stezky mezi Přimdou a Stráží. Foto P. Sokol, 2016. Abb. 10. Schlössl, Katastergebiet Stráž. Hohlwege westlich von Stráž auf der Trasse des Landespfades zwischen Přimda und Stráž. Foto P. Sokol, 2016. 
o stavbě hradu Němci i na české straně k roku 1121 (Široký-Nováček 1998, 59), mylně vykládanou jako první zmínku o Přimdě (k tomu Sokol 2014a, 19). Vznik (nebo obnovení) Přimdy a poté Tachova byl zřejmě reakcí na tento postup z německé strany s cílem zabezpečit hranici a důležitou cestu k ní co nejblíže k německé straně, následovala vlastní kolonizace území přiléhající k pohraničnímu hvozdu. Důležité bylo založení kladrubského kláštera v roce 1115 a následně tedy Přimdy a Tachova, přičemž právě mezi těmito body vedly stěžejní komunikace směrem přes hranici (Široký-Nováček 1998, 59).

Ke konci 12. století mělo území mezi Tachovskou brázdou a pohraničním hvozdem stále charakter spíše izolovaný a ovlivněný strategickými hledisky zájmů knížete, včetně zajištění průběhu obou větví zemské stezky (Široký-Nováček 1998, 60, 62). V první polovině 13. století se zformovalo osídlení v místech dnešního městečka Přimdy a zřejmě i tehdy vznikla zeměpanská Stráž. Zahuštění osídlení můžeme předpokládat až od druhé poloviny 13. do první poloviny 14. století (Široký-Nováček 1998, 62, 64).

V období po vzniku Stráže (s jistotou první polovina 13. století, možnost pro 12. století je otevřená) byl průběh přimdské cesty v blízkosti hranic následující. Od hranice směřovala cesta pod Přimdu, nejpozději od poloviny 13. století již s podhradním osídlením, následně směřovala (obr. 8) přímo k opevnění Zámeček (Nový hrad) a odtud do Stráže (obr. 9, 11 a 12), kterou procházela ve směru západ-východ (k tomu též Široký-Nováček 1998, 64). Úvozy severně od Přimdy (k. ú. Újezd pod Přimdou) spolu s keramikou z 13. století zřejmě dokládají obcházení návrší s hradem s cílem vyhnout se placení cla, a tedy již existující celnici v přimdském podhradí (Široký-Nováček 1998, 64, 67; celnici v Přimdě pro 13. století předpokládal i Vávra 1973, 63).

Zeměpanský dozor nad Norimberskou cestou se začal rozvolňovat $\mathrm{v}$ druhé polovině 13. století (Široký-Nováček 1998, 67). Zda se to však týkalo i úseku od Stráže k zemské hranici, není jisté. Hrad Přimda nebyl zřejmě až do doby Jana Lucemburského zastavován a Stráž byla rovněž ještě v tomto období zeměpanská. Přestože Stráž zůstávala ještě ve 14. století komorní, ztrácela význam jako důležitý bod na zemské stezce ve prospěch švamberského Boru, což vedlo i k změnám trasy cesty (Široký-Nováček 1998, 67).

Cesta přes Stráž zůstávala s výkyvy důležitá ještě do první poloviny 18. století (Postránecká-Wasková 2008, 77; Široký-Nováček 1998, 67; Minátová 1979, 29-33; Vávra 1973, 59-61; Roubík 1938, 31-32), užívána ale byla jistě i poté (v některých úsecích zanikla až v 2. polovině 20. století). Historické využívání cesty v blízkosti opevnění bylo potvrzeno i nálezem kamene s vytesaným číslem XV asi 300 m severovýchodně od opevnění při okraji cesty držící směr navazujících úvozů (obr. 13 a 19).

\section{Archeologický výzkum, jeho metody a výsledky}

Na povrchový průzkum lokality navázala fotografická dokumentace $\mathrm{z}$ dálkově ovládaného leteckého prostředku (obr. 12) a detailní geodetické zaměření totální stanicí (obr. 14 a 15; Koštial 2016). Z dat leteckého laserového skenování 5. generace (ČÚZK Praha) po robustní filtraci byl proveden model reliéfu terénu s př́ičnými řezy a trojrozměrný model lokality (obr. 16-18). ${ }^{2}$ Vše zprostř̌edkovává potřebné detaily vzhledu objektu.

Geofyzikální průzkum proběhl na pěti plochách o celkové rozloze 1,1 ha vytyčených v místech předpokládaného případného osídlení či jiné lidské aktivity (obr. 19), na vnitřní ploše opevnění nebylo měření provedeno pro př́itomnost vzrostlé i popadané vegetace. Anomálie zjištěné severozápadně od opevnění naznačovaly přítomnost zahloubených objektů s možností liniového charakteru. Obdobné výsledky přineslo i měření východně od opevnění za vodotečí (Křivánek 2017, 10).

Na geofyzikální průzkum navázal průzkum detektorem kovů, který se soustředil nejdříve na plochy s anomáliemi zjištěnými geofyzikálním měřením, následně byla detektorem prozkoumána až na nepřístupná místa celá vnitřní plocha opevnění, koruna vnitřního valu, prostor

2 Zpracování dat a modelu reliéfu O. Malina, řezů objektem a modelu lokality F. Prekop. 
vstupu, koruna východního a jižního vnějšího valu a plocha jižně a východně vnějšího valu (obr. 20). Pro geofyzikálně určené plochy nepřinesl tento průzkum pozitivní zjištění, v průběhu dalšího průzkumu byly získány železné předměty vně i uvnitř opevnění.

Následný výzkum proběhl prostřednictvím šesti sond, z nichž umístění dvou (A a B) vně opevnění reagovalo na výsledky geofyzikální prospekce, ostatní se snažily postihnout charakter opevnění (obr. 20). Na vnitřní ploše byly položeny dvě sondy ( T a L), v obou př́padech se dotýkaly paty valu na východní a na jižní straně, přičemž sonda $\mathrm{T}$ byla vyhloubena $\mathrm{v}$ místě nálezu

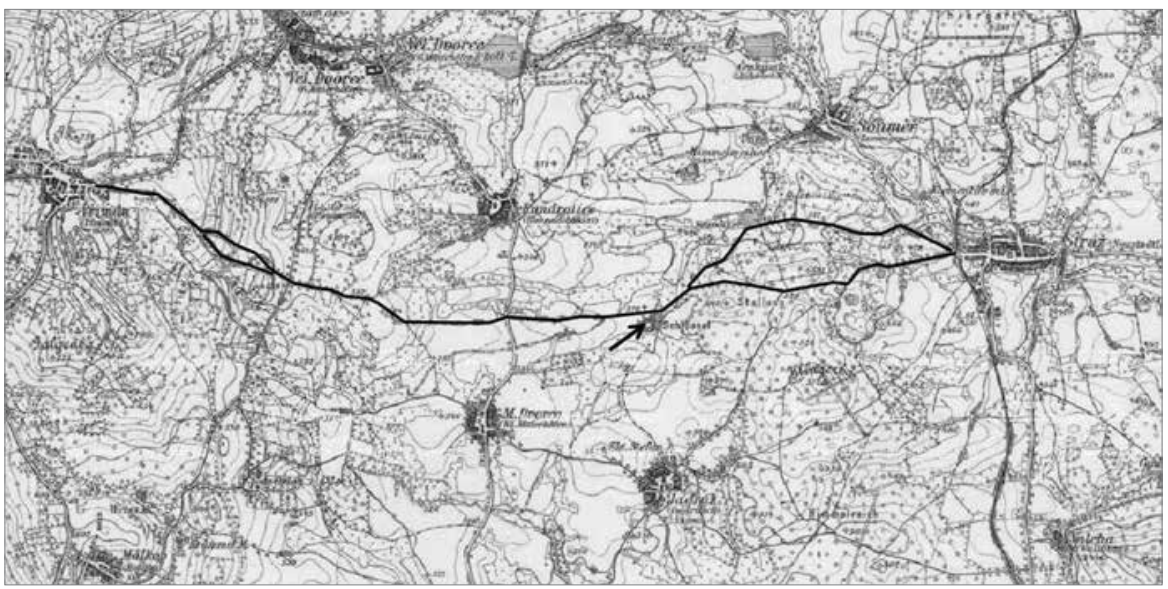

Obr. 11. Zámeček, k. ú. Stráž. Vyznačení trasy zemské stezky v úseku mezi Přimdou a Stráží na základě map a dochovaných úvozů na podkladu reambulace mapy 3. vojenského mapování z roku 1925 (Archivní mapy). Šipkou označena poloha Zámečku. Upravil P. Sokol.

Abb. 11. Schlössl, Katastergebiet Stráž. Kennzeichnung der Trasse des Landespfades im Abschnitt zwischen Přimda und Stráž anhand von Karten und erhaltenen Hohlwegen nach Vorlage der Reambulation einer Karte der 3. militärischen Kartierung aus dem Jahr 1925 (Archivkarte). Mit Pfeil gekennzeichnet die Lage des Schlössls. Bearbeitet von P. Sokol.

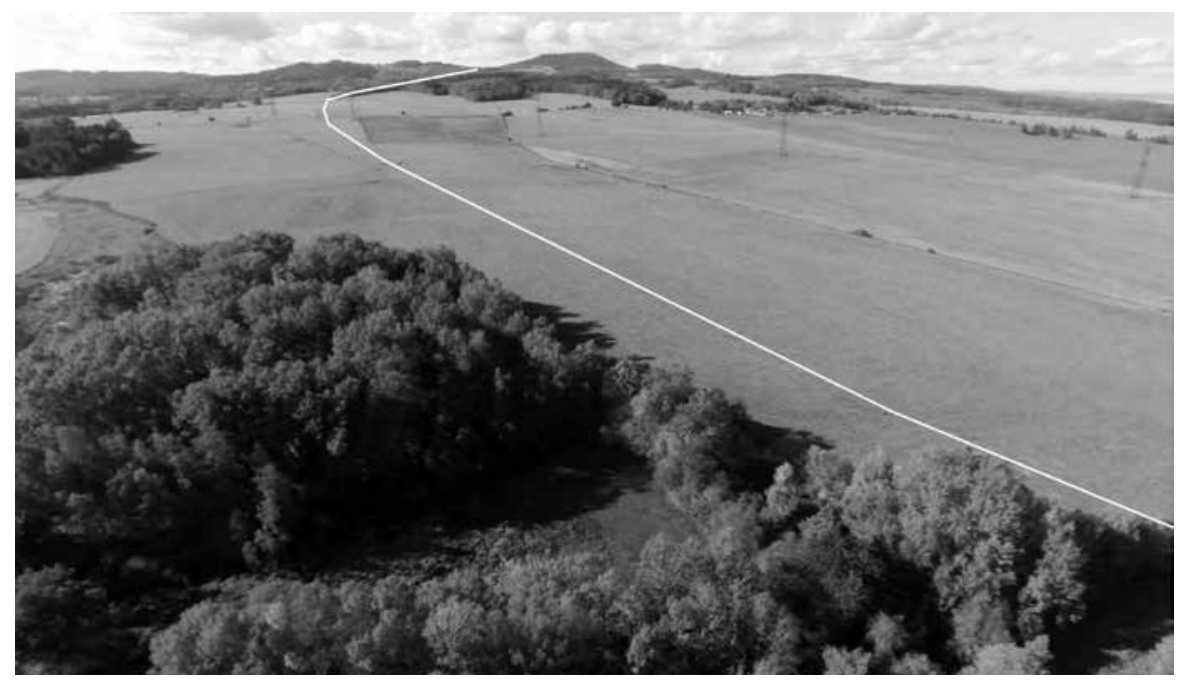

Obr. 12. Zámeček, k. ú. Stráž. Orientační vyznačení trasy zemské stezky v úseku od Zámečku (lesík vpředu vlevo) směrem k Přrimdě. Foto J. Ch. Koštial, 2016, upravil P. Sokol.

Abb. 12. Schlössl, Katastergebiet Stráž. Kennzeichnung des Trassenverlaufs des Landespfades im Abschnitt vom Schlössl (vorne links das Wäldchen) in Richtung Přimda. Foto J. Ch. Koštial, 2016, bearbeitet von P. Sokol. 


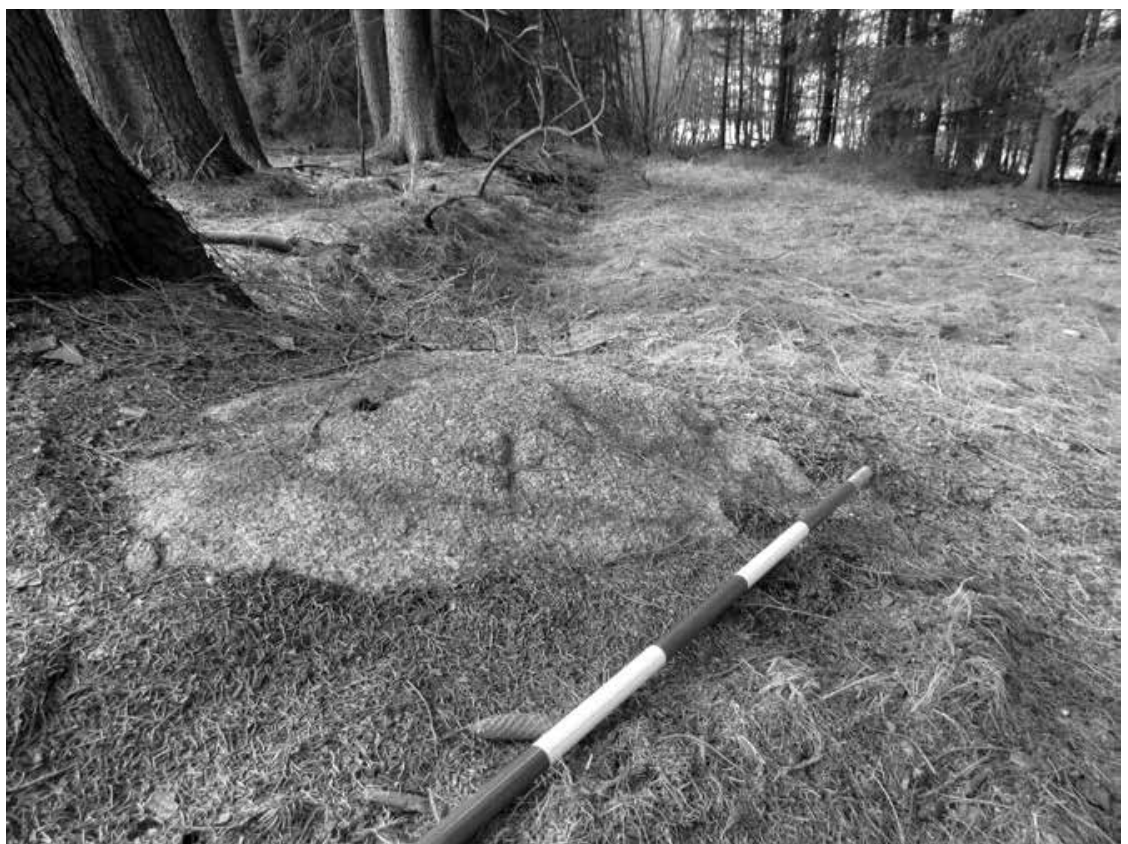

Obr. 13. Zámeček, k. ú. Stráž. Kámen s římskou číslicí při okraji cesty v trase úvozů severovýchodně od Zámečku. Pohled od severovýchodu. Foto F. Kasl, 2019.

Abb. 13. Schlössl, Katastergebiet Stráž. Stein mit römischer Ziffer am Wegrand auf der Trasse der Hohlwege nordöstlich vom Schlössl. Blick aus Nordosten. Foto F. Kasl, 2019.

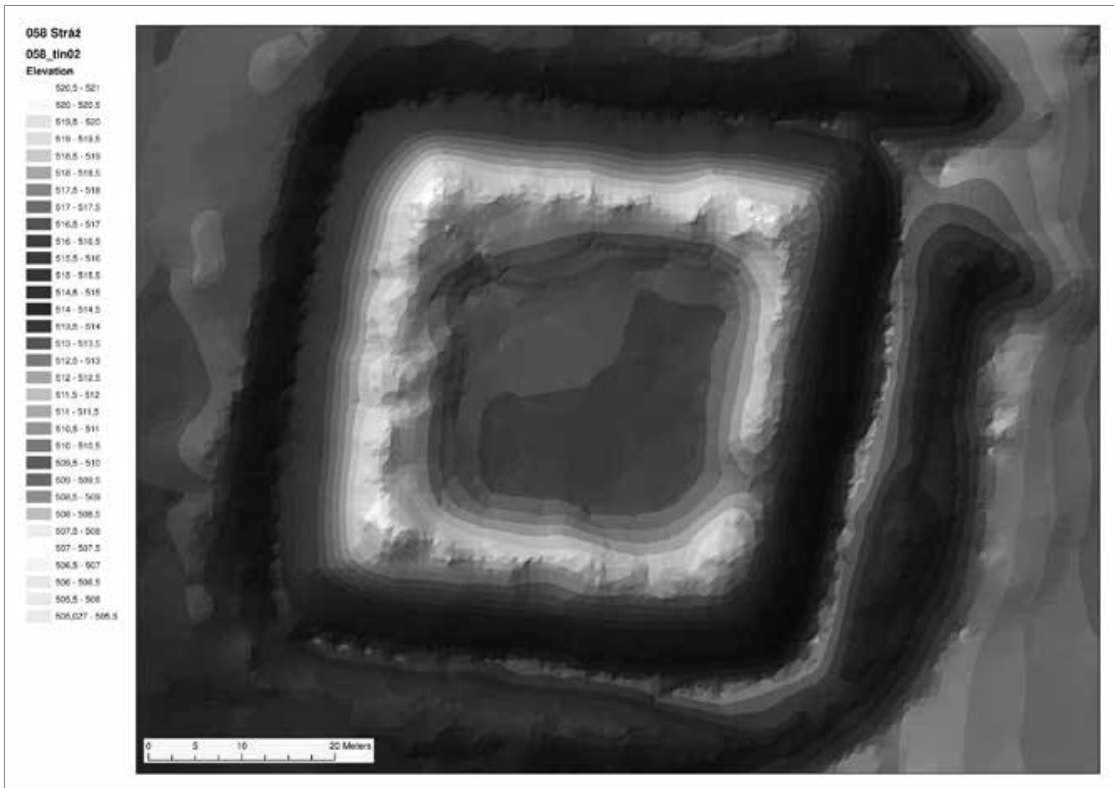

Obr. 14. Zámeček, k. ú. Stráž. Výškový model objektu na základě geodetického zaměření. Na koruně severního, západního i jižního valu patrné sníženiny (zářezy), na východní straně vstup. Zhotovil J. Ch. Koštial, 2016.

Abb. 14. Schlössl, Katastergebiet Stráž. Höhenmodell des Objektes anhand der geodätischen Vermessung. Auf der Krone des nördlichen, westlichen und südlichen Walls sind Mulden (Einschnitte) erkennbar, an der Ostseite der Eingang. Erstellt von J. Ch. Koštial, 2016. 


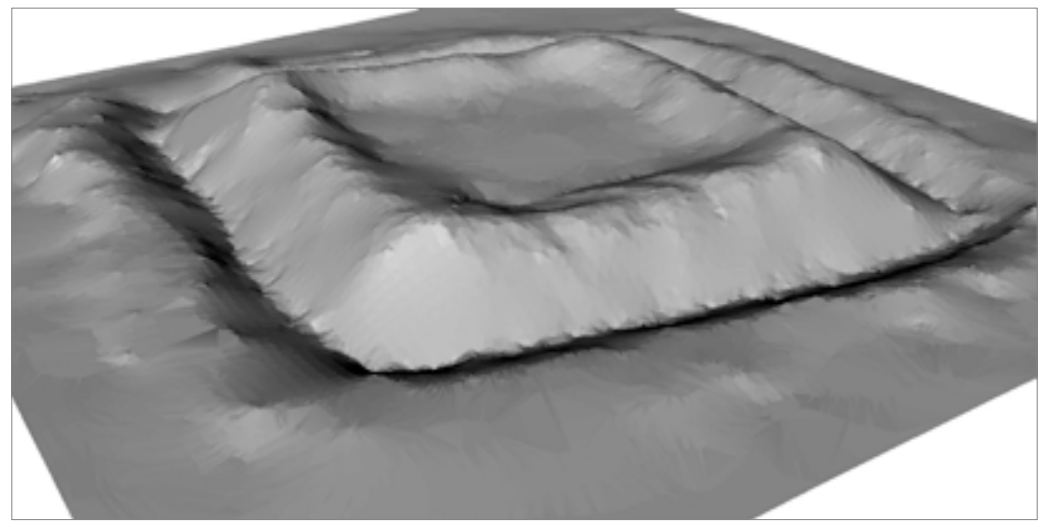

Obr. 15. Zámeček, k. ú. Stráž. Model objektu na základě geodetického zaměření. Pohled od severozápadu. Zhotovil J. Ch. Koštial, 2016.

Abb. 15. Schlössl, Katastergebiet Stráž. Modell des Objektes anhand der geodätischen Vermessung. Blick aus Nordwesten. Erstellt von J. Ch. Koštial, 2016.
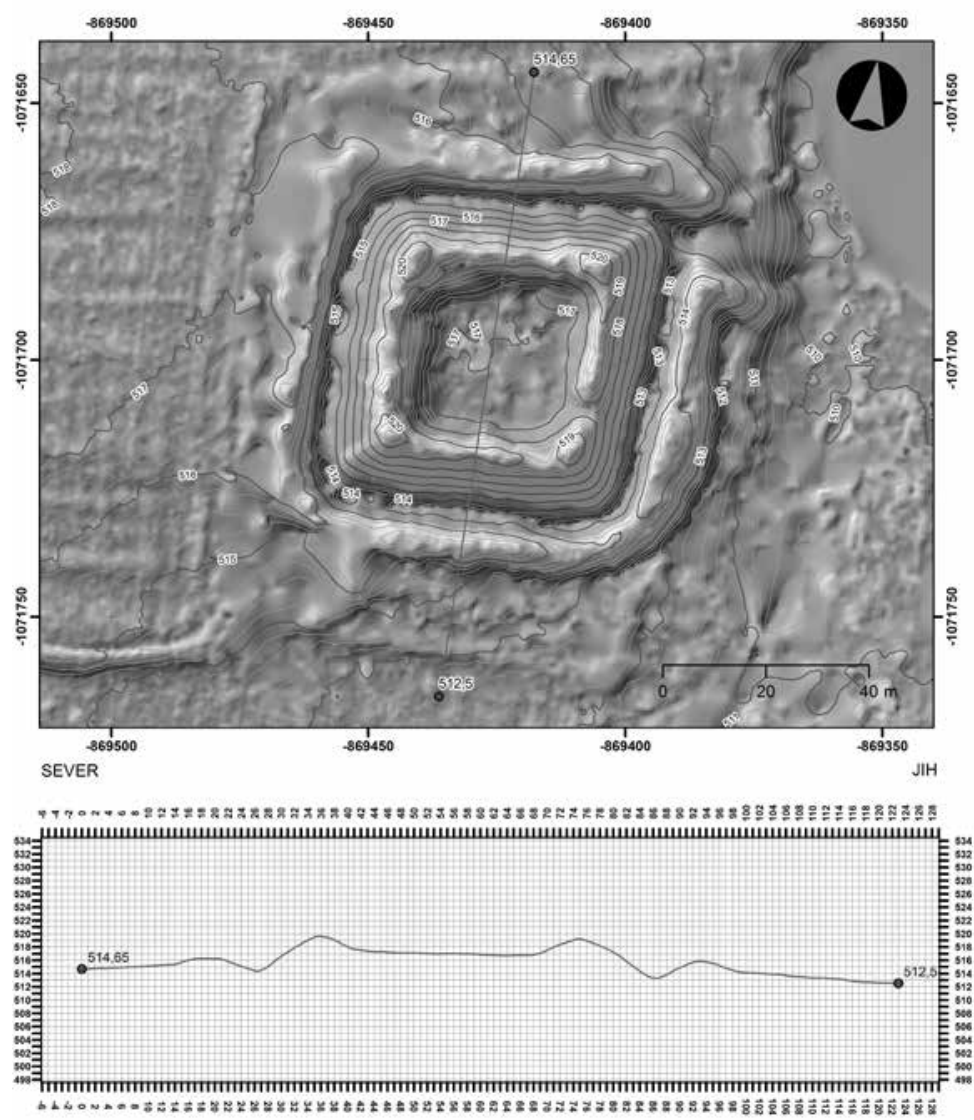

Obr. 16. Zámeček, k. ú. Stráž. Model objektu z dat leteckého laserového skenování po robustní filtraci (ČÚZK Praha) s profilem S-J. Zhotovil F. Prekop, 2016.

Abb. 16. Schlössl, Katastergebiet Stráž. Modell des Objektes anhand der Daten eines luftgestützten Laserscannings nach robuster Filterung (Tschechisches Amt für Landesvermessung und Kataster) mit Nord-Süd-Profil. Erstellt von F. Prekop, 2016. 

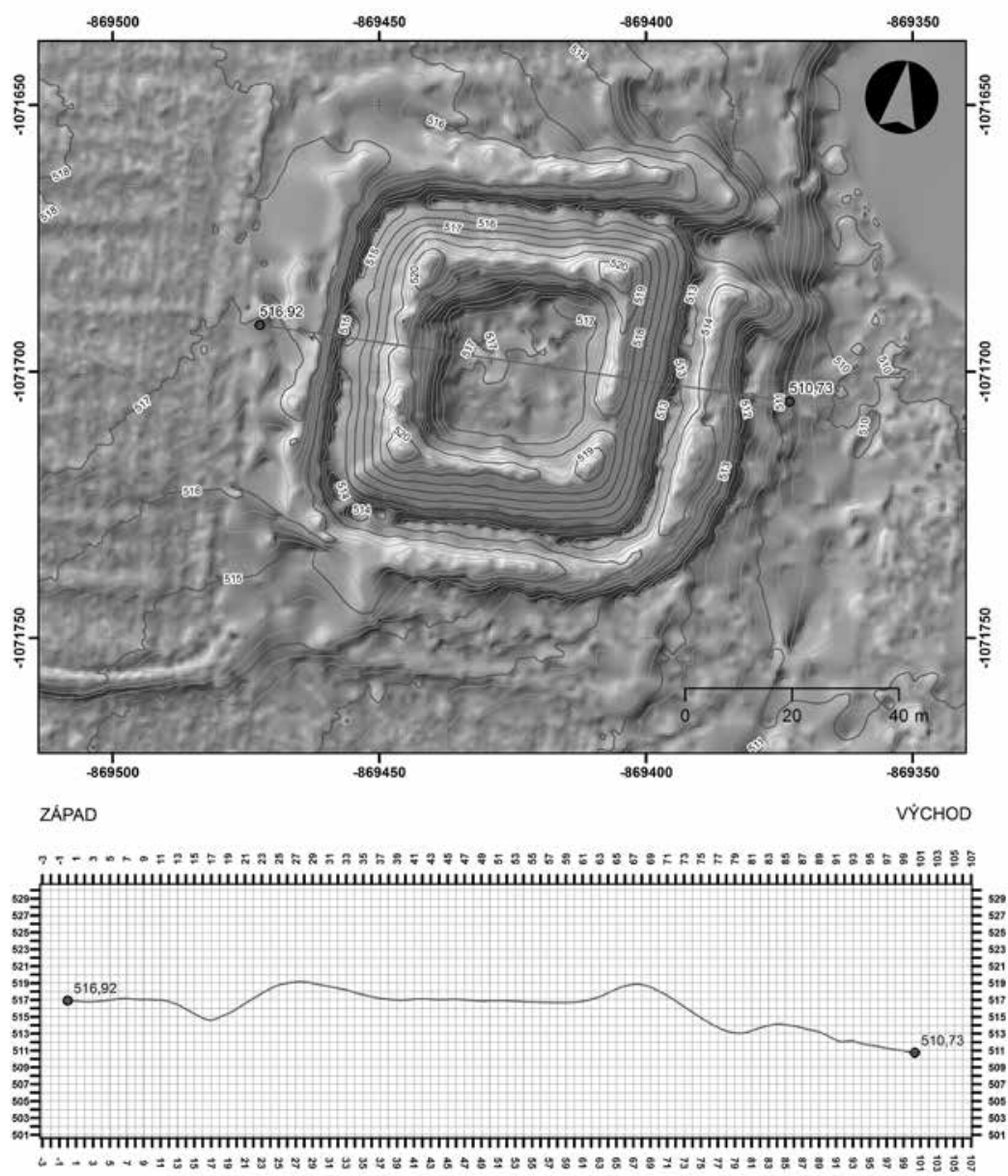

Obr. 17. Zámeček, k. ú. Stráž. Model objektu z dat leteckého laserového skenování po robustní filtraci (ČÚZK Praha) s profilem Z-V. Zhotovil F. Prekop, 2016.

Abb. 17. Schlössl, Katastergebiet Stráž. Modell des Objektes anhand der Daten eines luftgestützten Laserscannings nach robuster Filterung (Tschechisches Amt für Landesvermessung und Kataster) mit West-Ost-Profil. Erstellt von F. Prekop, 2016.

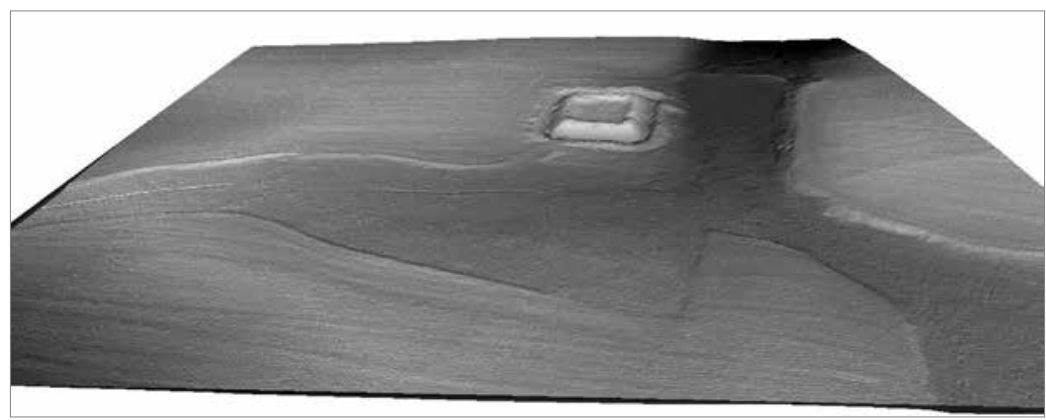

Obr. 18. Zámeček, k. ú. Stráž. 3D model lokality z dat leteckého laserového skenování po robustní filtraci (ČÚZK Praha). Pohled od jihu. Zhotovil F. Prekop, 2016.

Abb. 18. Schlössl, Katastergebiet Stráž. 3D-Modell der Fundstelle anhand der Daten eines luftgestützten Laserscannings nach robuster Filterung (Tschechisches Amt für Landesvermessung und Kataster). Blick aus Süden. Erstellt von F. Prekop, 2016. 
třmenu při detektorovém průzkumu. Na západní straně lokality pak byly položeny sondy na koruně vnitřního valu a na dně př́íkopu ( $\mathrm{V}$ a $\mathrm{P}$ ).

Ačkoli se sondy dotkly jen velmi malé části plochy objektu, nelze je vnímat jen v rovině poměru odkryté plochy $\mathrm{k}$ celkové rozloze objektu. Podstatné je rozložení těchto ploch s cílem postihnout různé části objektu a jeho jednotlivé základní prvky. Sondy A a B vně opevnění nepřinesly pozitivní zjištění týkající se osídlení a využití lokality, anomálie naznačené geofyzikálním měřením byly zř̌jmě důsledkem zrudnění rohovců (Lachman 2018). Ve svrchních úrovních sond $\mathrm{T}$ a $\mathrm{L}$ byla zjištěna kamenná vrstva (destrukce) o hloubce $30 \mathrm{~cm}$ podél vnitřní paty valu. V sondě T se pod kamennou destrukcí nacházela „spáleništní “ vrstva o hloubce ca $25-30 \mathrm{~cm}$ obsahující fragmenty keramiky a železné předměty na shořelé dřevěné konstrukci, nasedající na úroveň původního terénu - navětralého podloží. Důležitou část zmíněné „spáleništní "vrstvy tvořily spálené trámy z borového dřeva (se šířkou ca $24 \mathrm{~cm}$ ) položené pravidelně vedle sebe, s jedním kratším, šikmo ležícím trámkem (obr. 21-23). Na těchto trámech ležely i železné předměty (ostruha, dva třmeny totožného tvaru a přezka; obr. 28 a 29). Umístění kamenů podél trojboké jamky o hloubce $40 \mathrm{~cm}$ v severozápadním rohu sondy působí jako obložení vertikálně upevněného dřevěného sloupu/trámu.

Důležité zjištění přinesla i sonda V v jednom ze „zářezư“" na koruně západního valu. Sonda do své maximální hloubky $1,5 \mathrm{~m}$ ukázala pouze pískový charakter valu bez jakýchkoliv viditelných příměsí, zásahů a konstrukčních prvků, a potvrdila tak zjištění uváděné již Sedláčkem. Základny valu nebylo ručně kopanou sondou malých rozměrů dosaženo. Sonda P napříč západním příkopem (obr. 24 a 25) odkryla souvrství, jehož součástí byla tenká uhlíkatá a popelovitá vrstvička. Dno příkopu bylo vyplněno jílovým sedimentem, na samém dně s hlinitou příměsí indikující antropogenně přemístěný materiál (Lachman 2018). Výplň této jílové vrstvy obsahovala i ohořelé kusy jedlových dřev.

Situace odkryté sondami v objektu můžeme považovat za neporušené př́ípadnými pozdějšími zásahy, spojenými např́iklad s hypotetickou úpravou objektu. Markantní to je nejen u západního př́ikopu a koruny vnitřního valu, ale především v sondě $\mathrm{T}$ na východním okraji vnitřní plochy, kde se pod povrchem současného terénu dochovala $\mathrm{v}$ ploše část spálené dřevěné konstrukce a na ní se nacházející soubor jezdecké výstroje. Současně žádná z odkrytých situací nenasvědčuje vícefázovému osídlení (využití) objektu.

\section{Movité nálezy}

\section{Keramika}

Z povrchového průzkumu vnitřní plochy pochází dvanáct zlomků kuchyňské a stolní keramiky, ze sondy T (vrstva 3; obr. 23) devět zlomků a po jednom zlomku ze sondy L (vrstva 2 kamenná destrukce u paty valu) a $\mathrm{P}$ (vrstva 2; obr. 24). Jde převážně o zlomky výdutí a den nádob, menších rozměrů, bez jednoznačně datovatelných znaků (profilace a výzdoby). Pouze jeden zlomek dna nesl na sobě hrnčiřskou značku. Nádoby byly zhotovené obtáčením bez povrchové úpravy, výpal byl pravděpodobně redukční, méně kvalitní. Příměsí byl křemičitý písek a jemnozrnná stř́ibřitá slída. Ze sondy T bylo získáno i patnáct menších zlomků nádobkových nebo komorových kachlů shodného charakteru (obr. 26), zřejmě oxidačního výpalu, pocházejících nejspíše z jedněch kamen (Hrubá-Hrubý 2018). Vzhledem k početně malému souboru a jeho koncentraci $v$ jedné sondě nelze vyloučit př́itomnost pouze jediného kachle.

\section{Kov}

Většina kovových předmětů byla nalezena při detektorovém průzkumu. Celkově z výzkumu pochází 71 kovových předmětů, získaných průzkumem jak vlastního opevnění a nejbližšího okolí, tak i sousedních polí ve vazbě na zjištění geofyzikálního průzkumu. Z polí bylo získáno 20 předmětů, jejichž vztah k opevnění není průkazný. Z opevnění pak pochází 51 kovových 


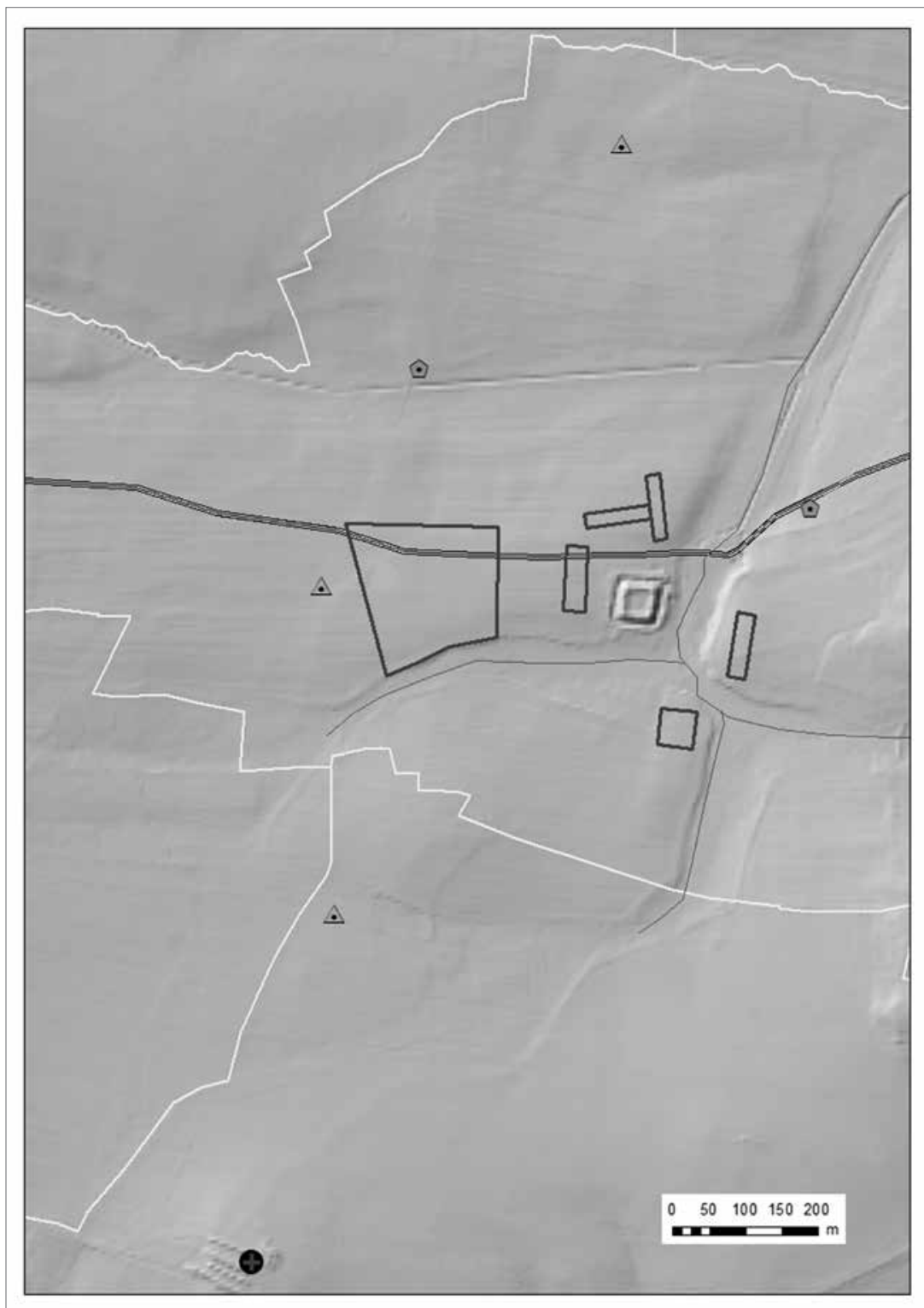

Obr. 19. Stínovaný reliéf okolí lokality s vyznačením rozsahu aplikace nedestruktivních metod. Trojúhelníkové symboly - místa nálezů keramiky během povrchových sběrů prováděných v roce 1982 (Nováěek 1993; u místa v blízkosti západního okraje velkého polygonu pole je předpoklad, že nálezy byly navzdory udané vzdálenosti od opevnění učiněny v ploše polygonu); pětiúhelník SZ od opevnění - místo nálezu raně středověké keramiky v roce 2019. Pětiúhelník SV od opevnění - kámen u okraje cesty ve směru původních úvozů s vytesanou římskou číslicí (XV?); velký polygon - plocha pole se systematicky provedenými povrchovými sběry v roce 2019. Menší obdélníky - plochy geofyzikálního průzkumu. Znázorněn je rovněž předpokládaný prủběh zemské stezky. Světlé linie - katastrální hranice. Zajímavý je průběh severní katastrální hranice k. ú. Stráž respektující polohy s náznaky raně stř̌edověkého osídlení i s jejich možným vztahem k opevnění (zázemí pro stanici?). Kř́ž̌̌ek - poloha dnes již zaniklého osamoceného kostela sv. Štěpána u Jadruže.

Abb. 19. Schattenrelief der Fundstellenumgebung mit Kennzeichnung des Umfangs der durchgeführten zerstörungsfreien Methoden. Dreiecke - Fundstellen der im Jahr 1982 während den durchgeführten Oberflächensammlungen entdeckten Keramik (Nováček 1993; an der Stelle in der Nähe des westlichen Randes des großen Polygonfeldes nimmt man an, dass die Funde trotz der angezeigten Entfernung von der Befestigung auf der Fläche des Polygons gemacht wurden); Fünfeck nordwestlich von der Befestigung - Fundort der 2019 
entdeckten frühmittelalterlichen Keramik. Fünfeck nordwestlich von der Befestigung - Stein am Wegrand in Richtung der ursprünglichen Hohlwege mit eingemeißelter römischer Ziffer (XV?); großes Polygon - Fläche des Feldes der im Jahr 2019 systematisch durchgeführten Oberflächensammlungen. Kleinere Rechtecke - geophysikalisch untersuchte Flächen. Der mutmaßliche Verlauf des Landespfades wird ebenfalls dargestellt. Helle Linien - Katastergrenzen. Interessant ist der Verlauf der nördlichen Katastergrenze des Katastergebietes Stráž, welche die Lagen mit Anzeichen einer frühmittelalterlichen Besiedelung und deren möglichen Bezug zur Befestigung respektiert (Hinterland für die Station?). Kreuz - Lage der heute bereits untergegangenen einzeln stehenden Stefanskirche bei Jadruž.

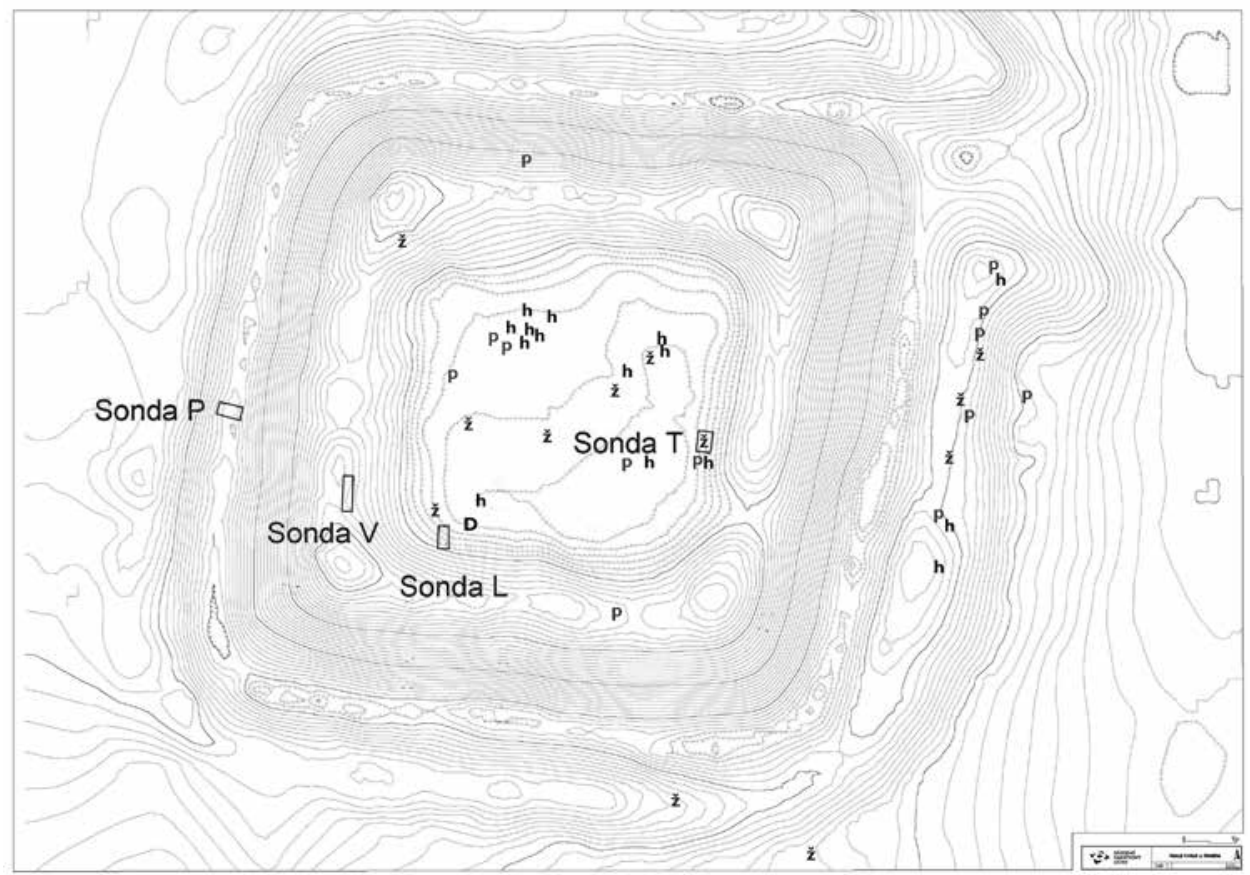

Obr. 20. Zámeček, k. ú. Stráž. Vrstevnicový plán objektu s vyznačenými sondami (obdélníky) a nálezy železných předmětů získaných detektorovým průzkumem. p - nález podkovy (resp. její části); h - hřebík (nejčastěji tzv. podkováky); ž - ostatní železné předměty; D - místo uložení souboru železných předmětů pocházejícího z předchozí nelegální detektorové činnosti. Abb. 20. Schlössl, Katastergebiet Stráž. Schichtenplan des Objektes mit Kennzeichnung der Sondierschnitte (Rechtecke) und der per Detektorsuche gemachten Funde von Eisengegenständen. p - Hufeisenfunde (bzw. Fragmente davon); h - Nägel (am häufigsten Hufeisennägel); $\breve{z}$ - sonstige Eisengegenstände; D - Stelle, an der sich eine aus vorhergehenden illegalen Detektorsuchen stammende Kollektion von Eisengegenständen befand.

předmětů či jejich zlomků. Čtyřicet z nich bylo nalezeno in situ, jedenáct pak uložených v menším výkopu provedeném při nelegálním detektoringu (obr. 20). Jde o 23 hřebů včetně ,podkovákư"s průřezem hlavy obdélníkovým, klínovým nebo lichoběžníkovým (obr. 27), dvanáct zlomků podkov (obr. 28) a o dalších tř̌ináct předmětů včetně objímek nástrojů na násadě, drobného nožíku s odsazeným trnem, drobné ruční pilky s výškou listu $16 \mathrm{~mm}$ a zuby trojúhelníkového tvaru, dvou ostruh s mírně prohnutými rameny a jednoduchým jehlancovým bodcem (v druhém prŕípadě s bodcem odděleným manžetou a s oválnými otvory pro řemen, obr. 29), páru symetrických třmenů s parabolickými rameny spojenými př́íčkou pod vrcholem, s jednoduchým obdélníkovým plným stupadlem s osově umístěným žebrem ze spodní strany (obr. 30 a 31), přezky opasku či řemene (obr. 30) a kování z barevného kovu. Zatímco podkováky a podkovy byly nalézány uvnitř i vně opevnění, pár třmenů spolu s ostruhou byl vyzvednut ze sondy $\mathrm{T}$ při vnitřní patě východního valu, předměty ležely na spálených trámech (obr. 23). Druhá ostruha a některé hřeby a zlomky podkov pochází z koruny severní části vnějšího východního valu a jejich výskyt zde může souviset s pravděpodobnou trasou př́stupu do opevnění (obr. 20). 


\section{Analýzy}

V průběhu výzkumu byla vyhodnocena geologie lokality a antrakologické vzorky ze sondy T. Z geologického hlediska se lokalita nachází v oblasti rohovců s obsahem železného zrudnění srovnatelného s obsahy železného zrudnění v brdských silicitech. Předpokládat lze i jednodušší využití tohoto zrudnění (Lachman 2018). Tomu mohou odpovídat stopy př́ípovrchové těžby na hřbetu mezi Zámečkem a Stráží zjištěné povrchovým průzkumem i leteckým laserovým skenováním (obr. 9). Souvislost této činnosti s opevněním však není jistá. Vlastní těleso valu je přirozeného písčitého charakteru, který umožňuje úvahu o vzniku opevnění jak vyhloubením příkopu, tak i částečným snížením vnitřní plochy, přičemž vznikl mohutný vnitřní val (Lachman 2018).

Při antrakologické analýze byl hodnocen soubor uhlíků a fragment nezuhelnatělého dřeva. Makrozbytky rostlin nebyly ve vzorcích zjištěny. Největší hmotnostní a početní zastoupení mezi vzorky měla z určených dřevin borovice, poté jedle a následně buk. Spálená konstrukce v sondě T byla tvořena borovým a jedlovým dřevem, jako palivové dřevo byl kromě borovice a jedle použit i buk. V okolí opevnění lze tedy počítat pro období fungujícího opevnění s bučinami, jedlobučinami a bory, případně s kyselými doubravami obsahujícími borovice (Kočárová 2019).

\section{Datování}

Datace nalezených zlomků keramiky je pouze orientační, charakter střepů ji v některých případech (několik zlomků ze sondy $\mathrm{T}$ ) ani neumožňoval. Keramické zlomky postrádaly jednoznačné datovatelné prvky (výzdoba, profilace), posuzován tak byl jen výpal a charakter

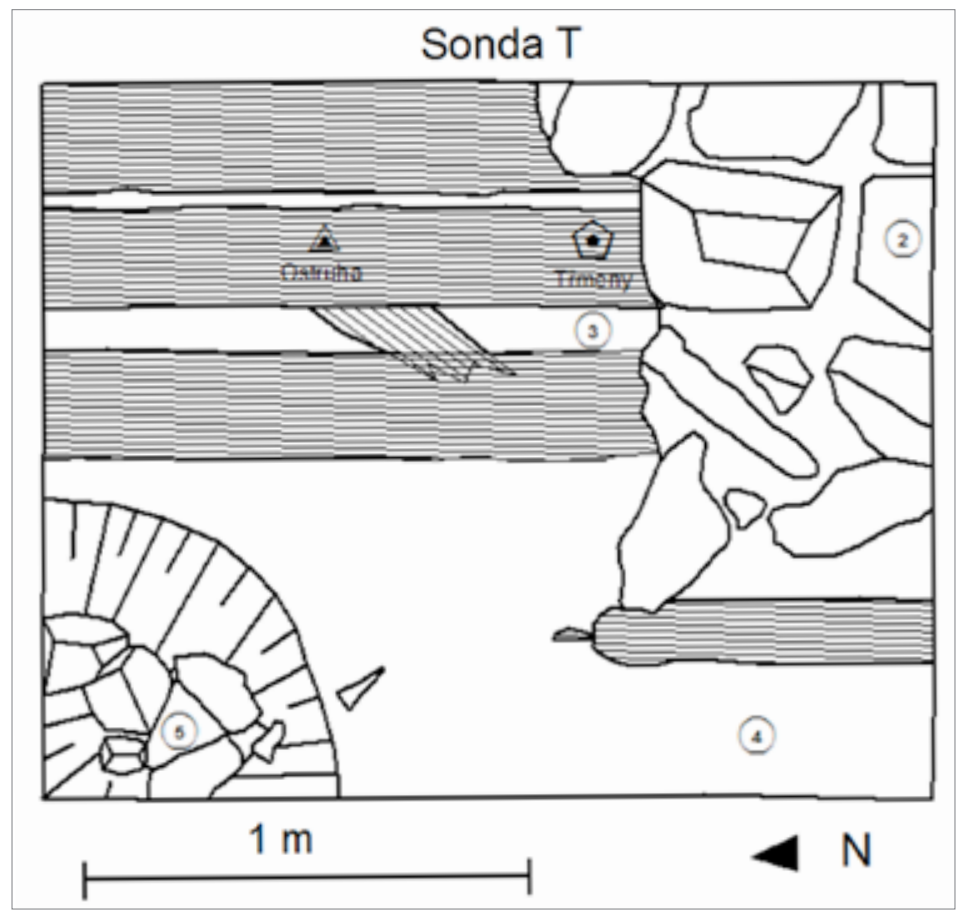

Obr. 21. Zámeček, k. ú. Stráž. Sonda T, úroveň spálené dřevěné konstrukce. Vyznačena místa nálezů třmenů a ostruhy. Kresba F. Kasl, 2019.

Abb. 21. Schlössl, Katastergebiet Stráž. Sondierschnitt T, Niveau der verbrannten Holzkonstruktion. Gekennzeichnete Fundorte der Steigbügel (Fünfeck) und des Sporns (Dreieck). Zeichnung F. Kasl, 2019. 


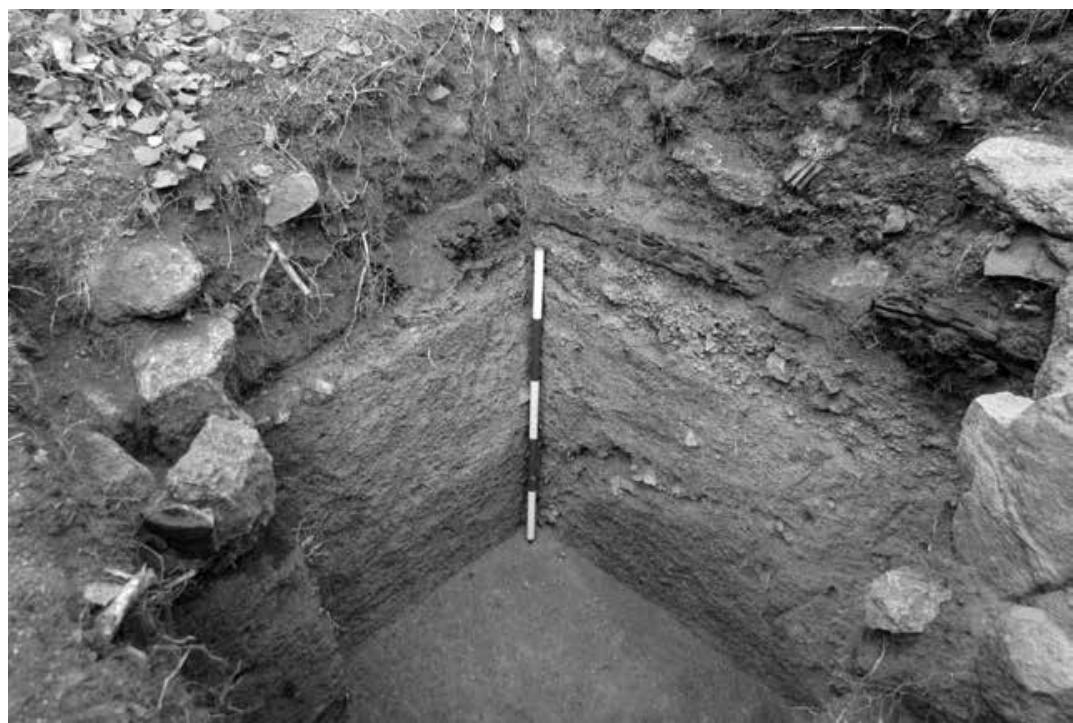

Obr. 22. Zámeček, k. ú. Stráž. Sonda T po dokončení. Pohled od jihozápadu. V úrovni nad trasírkou patrná vrstva spálené dřevěné konstrukce. Foto F. Kasl, 2018.

Abb. 22. Schlössl, Katastergebiet Stráž. Sondierschnitt T nach Fertigstellung. Blick aus Südwesten. In Höhe oberhalb der Trassierstange ist eine Schicht der verbrannten Holzkonstruktion sichtbar. Foto F. Kasl, 2018.

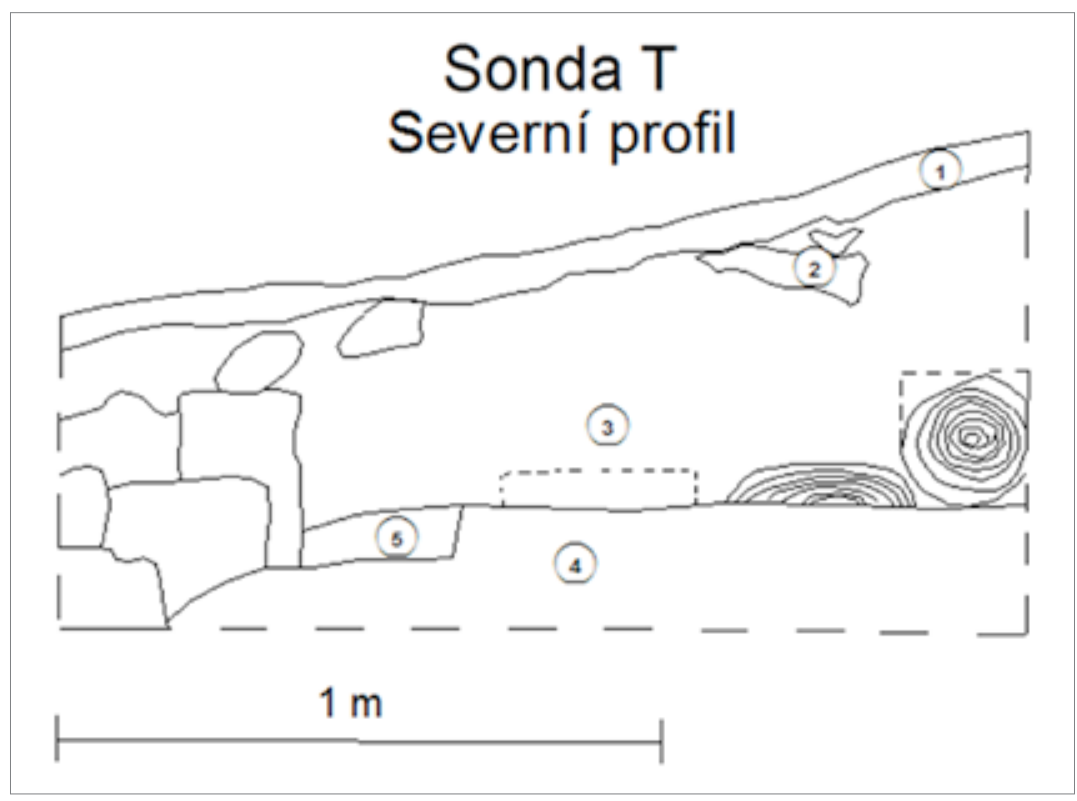

Obr. 23. Zámeček, k. ú. Stráž. Sonda T, severní profil se spálenou dřevěnou konstrukcí. 1 - svrchní půda; 2 - kamenná destrukce ve východní části sondy; 3 - „spáleništní“ vrstva s fragmenty keramiky, kovovými předměty a spálenou dřevěnou konstrukcí (z ní odebrán vzorek č. 1 na C14); 4 - navětralé podloží; 5 - vkop pro osazení kůlu? Kresba F. Kasl, 2019.

Abb. 23. Schlössl, Katastergebiet Stráž. Sondierschnitt T, Nordprofil mit verbrannter Holzkonstruktion. 1 - Oberboden; 2 - Zerstörungsschicht aus Stein im östlichen Teil des Sondierschnittes; 3 - „Brandstellenschicht" mit Keramikfragmenten, Metallgegenständen und verbrannter Holzkonstruktion (aus welcher Probe Nr. 1 für die C14-Bestimmung entnommen wurde); 4 - verwitterter Unterboden; 5 - Aushebung zum Setzen von Pfählen? Zeichnung F. Kasl, 2019. 


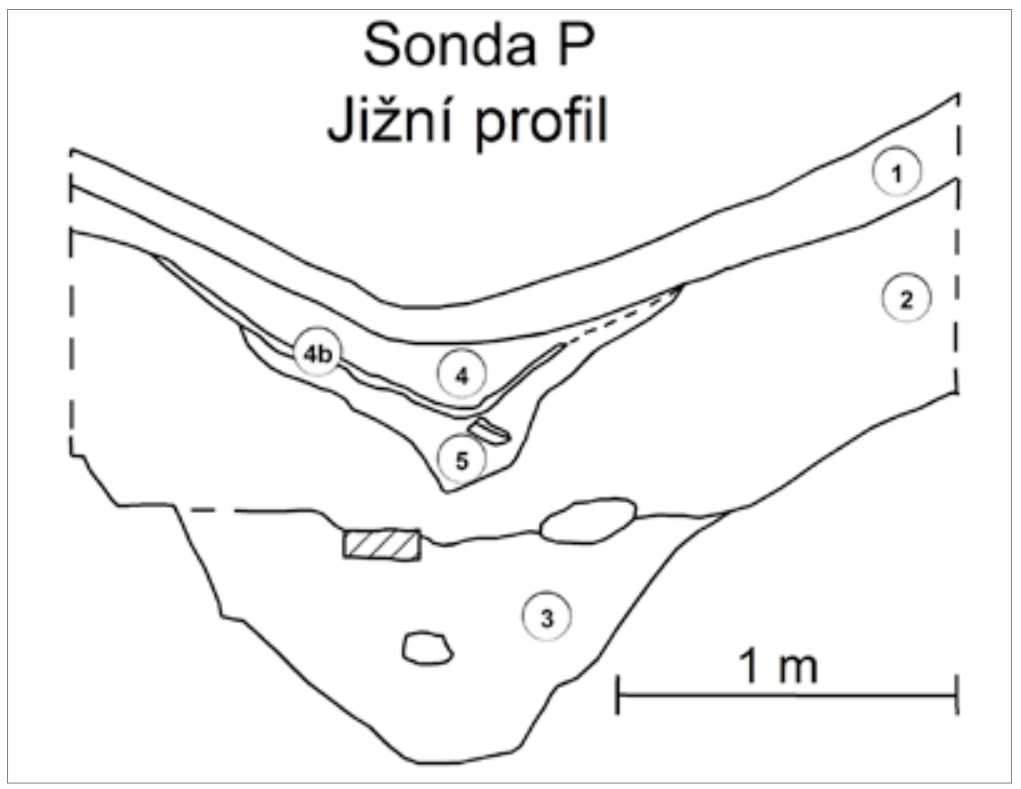

Obr. 24. Zámeček, k. ú. Stráž. Sonda $P$, jižní profil. 1 - svrchní půda; 2 - písčitá vrstva s kameny (zlomek keramiky doby bronzové); 3 - jílový sediment, ve spodní části s hlinitou př́měsí, s kameny a kusy ohořelých jedlových dřev (na rozhraní vrstev 2 a 3 trámek, z něhož byl odebrán vzorek č. 3 na C14, vzorek č. 4 odebrán z jedlového dřeva u dna příkopu); 4, 4b, 5 - kompaktní souvrství s kameny; 4b - uhlíky s popelem. Kresba F. Kasl, 2019.

Abb. 24. Schlössl, Katastergebiet Stráž. Sondierschnitt P, Südprofil. 1 - Oberboden; 2 - Sandschicht mit Steinen (Keramikfragment aus der Bronzezeit); 3 - Lettensediment, im unteren Teil mit Lehmbeimischung, mit Steinen und abgebrannten Tannenholzstücken (an der Grenze der Schichten 2 und 3 der Balken, von dem Probe Nr. 3 für die C14-Bestimmung entnommen wurde, Probe Nr. 4 wurde vom Tannenholz am Boden des Grabens entnommen); 4, 4b, 5 - kompakte Schichtenfolge mit Steinen; 4b - Holzkohle mit Asche. Zeichnung F. Kasl, 2019.

keramické hmoty. Zlomek keramiky z vrstvy $2 \mathrm{v}$ sondě $\mathrm{P}$ pochází pravděpodobně $\mathrm{z}$ doby bronzové, ostatní keramické nálezy pak z období od přelomu 12. a 13. století po 14. století (spíše jeho 1. polovinu). Vzhledem k charakteru zlomků keramiky, jejich nálezovému kontextu a $\mathrm{k}$ datům z absolutního datování (viz níže) je možné uvažovat o datování keramiky spíše do 13. století. Využití kachlů (vzhledem k malé velikosti zlomků nelze rozhodnout, zda šlo o kachle nádobkové nebo komorové) nelze pro období 13. století jednoznačně odmítnout. ${ }^{3}$ Kovové předměty až na výjimky, z nichž část pochází z průzkumu ploch v okolí opevnění, jsou datovány rámcově do středověku (nožík, pilka, zřejmě i objímky), v konkrétních případech pak do 12.-13. století. Podkováky odpovídají nejspíš typu 1 (Brunner 2007, obr. 1 na s. 2) rozšířenému v období ca 1000-1250. Do období 12.-13. století lze řadit pár třmenů (13. století), ostruhy (12.-13. století a 13. století) a podkovy (13. století). ${ }^{4}$ Kování ze slitiny nalezené v prostoru před jižním vnějším valem je řazeno obecně do středověku a nemusí, stejně jako některé další kovové předměty obecně datované do období středověku (např. objímky a nástroje), souviset s původní funkcí objektu.

Pro dendrochronologickou dataci byl použitelný pouze vzorek ze sondy $\mathrm{P}$, pocházející $\mathrm{z}$ úrovně $0,5 \mathrm{~m}$ nad původním dnem př́íkopu, z rozhraní uloženin a následných splachových vrstev (obr. 24 a 25). Šlo o jedlové dřevo bez podkorního letokruhu, smýcené po roce $1215 .^{5}$

\footnotetext{
3 Za konzultaci keramických nálezů děkujeme H. a J. Hrubým, J. Ornovi, K. Nováčkovi, L. Čapkovi, J. Hložkovi a L. Hoblovi.

4 Za konzultaci třmenů a ostruh děkujeme J. Klápště a I. Štefanovi, za analýzu souboru kovových předmětů pak M. Čechurovi.

5 Dendrochronologické datování provedl T. Kyncl.
} 


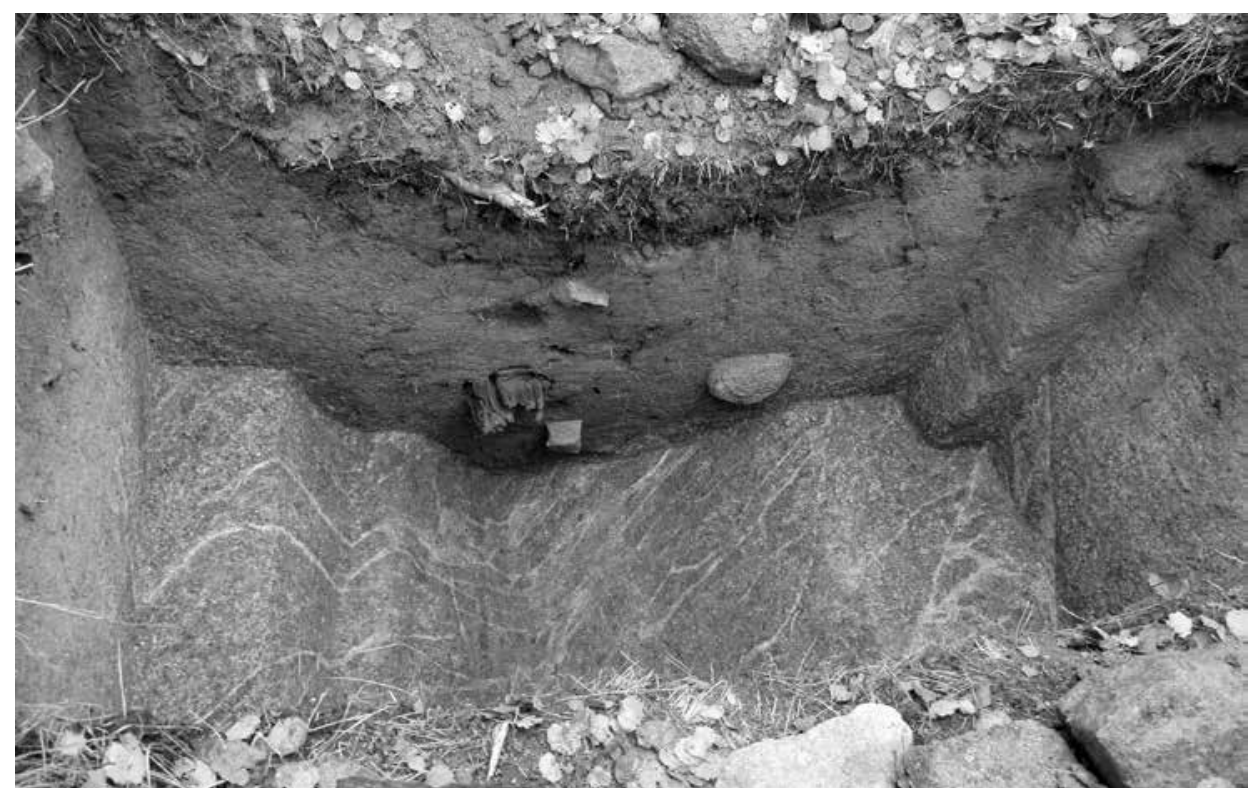

Obr. 25. Zámeček, k. ú. Stráž. Sonda $P$, jižní profil. Nad dnem v profilu část dřeva, z níž byly odebrány vzorky pro dendrochronologii a radiokarbonové datování. Foto F. Kasl, 2018.

Abb. 25. Schlössl, Katastergebiet Stráž. Sondierschnitt P, Südprofil. Über dem Boden im Profil der Teil des Holzes, von dem die Proben für die Dendrochronologie und Radiokarbondatierung entnommen wurden. Foto F. Kasl, 2018.

Ze sond T, L a P byly odebrány čtyři vzorky dřeva na radiokarbonové datování. ${ }^{6}$ Vzorky tak pochází z různých míst objektu (východní a jižní okraj vnitřní plochy, západní příkop) a v mezích daných výzkumem eliminují případnou nahodilost získaných dat. Analyzován byl vzorek (č. 1) ze spálené konstrukce, která byla součástí „spáleništní“ vrstvy v sondě T a na níž se nacházely předměty jezdecké výstroje (obr. 22 a 23), vzorek (č. 2) na povrchu zuhelnatělého dřeva $z$ vnitřní paty jižního hlavního valu ze sondy L, vzorek (č. 3) na povrchu zuhelnatělého dřeva jedlového trámu ze sondy $\mathrm{P}, \mathrm{z}$ úrovně $0,5 \mathrm{~m}$ nad původním dnem příkopu (rozhraní uloženin a následných splachových vrstev), tedy ze dřeva shodného s tím, z něhož pocházel vzorek pro dendrochronologii, a vzorek (č. 4) dřeva z původního dna př́íkopu ze stejné sondy (obr. 24). Kalibrovaná data z těchto vzorků jsou seřazena chronologicky, údaj v závorce označuje hodnotu mediánu:

Vzorek č. 2 z vnitřní paty valu v sondě L: 1154-1218 (1176), vzorek č. 4 ze dna př́íkopu v sondě P: 1164-1223 (1199), vzorek č. $3 \mathrm{z}$ hloubky $0,5 \mathrm{~m}$ nad dnem příkopu v sondě $\mathrm{P}$ : 1154-1218 (1176), dendrochronologicky však zpřesněno za rok 1215, a vzorek č. 1 ze spálené konstrukce v sondě T: 1205-1259 (1223).

Doposud získaná radiokarbonová data pochází pouze z dřev bez dochovaných podkorních letokruhů, čímž je limitována jejich hodnota pro přesnější datování. Toto omezení je však alespoň zčásti vyváženo vzájemnou shodou získaných dat a nelze uvažovat o diametrálně odlišném chronologickém zařazení analyzovaných vzorků.

Současně je radiokarbonové a dendrochronologické datování ve vzájemné shodě s datováním kovových předmětů a minimálně zčásti i keramiky. Jednotlivá datování tak společně poskytují dostatečnou oporu pro jednoznačné chronologické zařazení do druhé poloviny 12 . století

6 Provedla Poznań Radiocarbon Laboratory, za konzultaci výsledků děkujeme F. Prekopovi. 
až 13. století, při snaze o užší časové vymezení za cenu menší jistoty pak do konce 12 . století až první poloviny 13. století.

Opakované využití nebo pozdější úpravy objektu nebyly výzkumem prokázány. Vlastní datování keramických zlomků (bez chronologicky citlivých prvků) a obvyklé datování kachlů mohou naznačovat delší trvání objektu (nebo využití již zaniklého), než na jaké ukazují absolutní data i kovové, chronologicky však méně citlivé, nálezy. Vztah keramických zlomků k ostatním nálezům z dané vrstvy $\mathrm{v}$ sondě $\mathrm{T}$ a vztah $\mathrm{k}$ datům absolutního datování konstrukce však tomu prŕliš nenasvědčuje. Za současného stavu výzkumu a s ohledem na nízkou vypovídací schopnost souboru keramiky ze sondy T nelze pouze na základě keramických nálezů o trvání objektu dále než do 13. století rozhodnout, ale ani ho vyloučit.

$\mathrm{V}$ případě kovových předmětů je s vědomím limitů jejich chronologické citlivosti na místě konstatování, že jde o situaci, kdy i takto limitované možnosti vzájemně u jednotlivých druhů nálezů korespondují, navíc víceméně i ve shodě s absolutním datováním. Naopak nic z dosavadních nálezů, a to ani v takové limitované míře, neukazuje na původ a využití objektu např́íklad $\mathrm{v}$ raně novověkém období.

Omezení dané malým rozsahem odkryvů bylo alespoň částečně vyváženo rozmístěním sond, takže absence mladších, novověkých nálezů má podle našeho názoru nepřehlédnutelný význam.

\section{Interpretace}

Před detektorovým průzkumem a sondáží jsme při pracovní interpretaci vycházeli z charakteru objektu, jeho rozměrů i morfologie, stavu dochování, umístění v krajině a vazby na komunikaci. Vzhled i umístění objektu neodpovídaly dosavadním interpretacím. Zřejmý byl vojenský charakter objektu, jehož existence byla úzce svázána s kontrolou úseku Norimberské cesty. Objekt jsme proto vzhledem k jeho charakteru považovali za redutu z období 17.-18. století (k tomuto typu lokalit např. Meduna 1990; Matoušek 2006; Krůl 2010; Ulrichová 2010). Šlo by o mohutnější, izolované opevnění, které jsme pracovně interpretovali jako dosud neznámou součást 14 km západním směrem vzdáleného bojiště u Rozvadova z roku $1621 \mathrm{~s}$ dochovanými prvky zemního opevnění (Matoušek-Hrnčiřík-Šámal 2018). Zámeček měl podle této hypotézy představovat týlové opevnění Tillyho armády na boční cestě k ztížení případného průniku oddílů Mansfeldova vojska. Středověké nálezy byly interpretovány jako doklady staršího využití plochy pozdějšího opevnění, jehož dnešní podoba mohla být také výsledkem mladší „přestavby“. Nešlo však o interpretaci bezproblémovou. Pochybnosti budily nezvyklá mohutnost opevnění, půdorys, převýšení vnitřního valu nad centrální plochou znemožňující jednoduchý přístup na
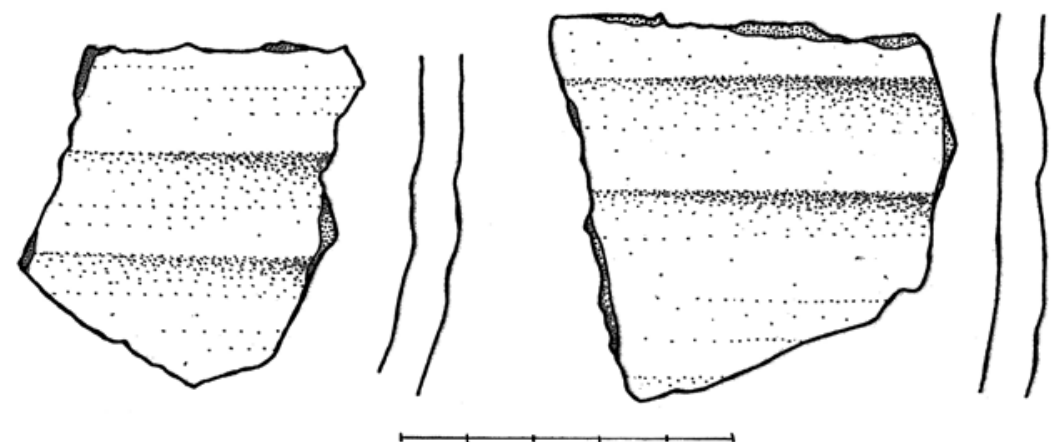

Obr. 26. Zámeček, k. ú. Stráž. Výběr zlomků kachlů (1 kachle?) z vrstvy 3 sondy T. Kresba H. Hrubá, 2019.

Abb. 26. Schlössl, Katastergebiet Stráž. Auswahl an Kachelfragmenten (1 Kachel?) aus Schicht 3 von Sondierschnitt T. Zeichnung H. Hrubá, 2019. 


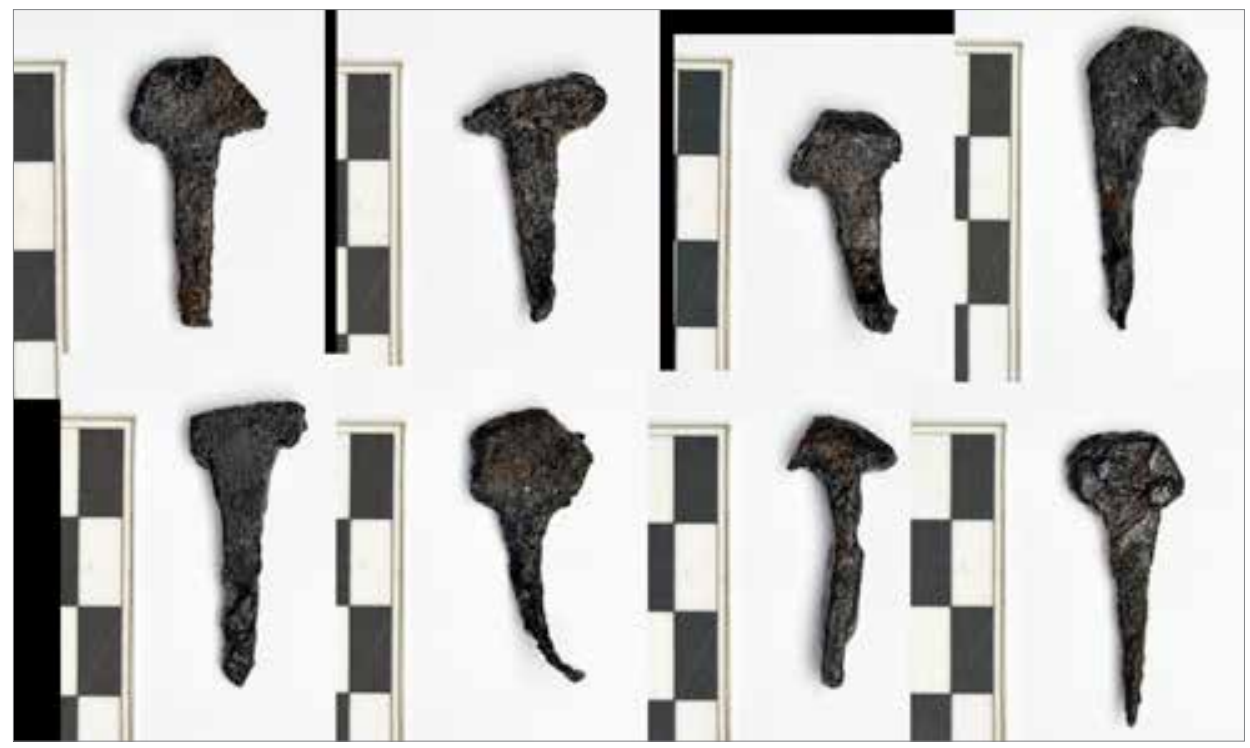

Obr. 27. Zámeček, k. ú. Stráž. Výběr z hř̌ebů „podkováků“ nalezených v objektu. Foto M. Zemánková (ZČM v Plzni), 2018, upravil P. Sokol.

Abb. 27. Schlössl, Katastergebiet Stráž. Auswahl an im Objekt gefundenen Hufeisennägeln. Foto M. Zemánková (Westböhmisches Museum in Pilsen), 2018, bearbeitet von P. Sokol.

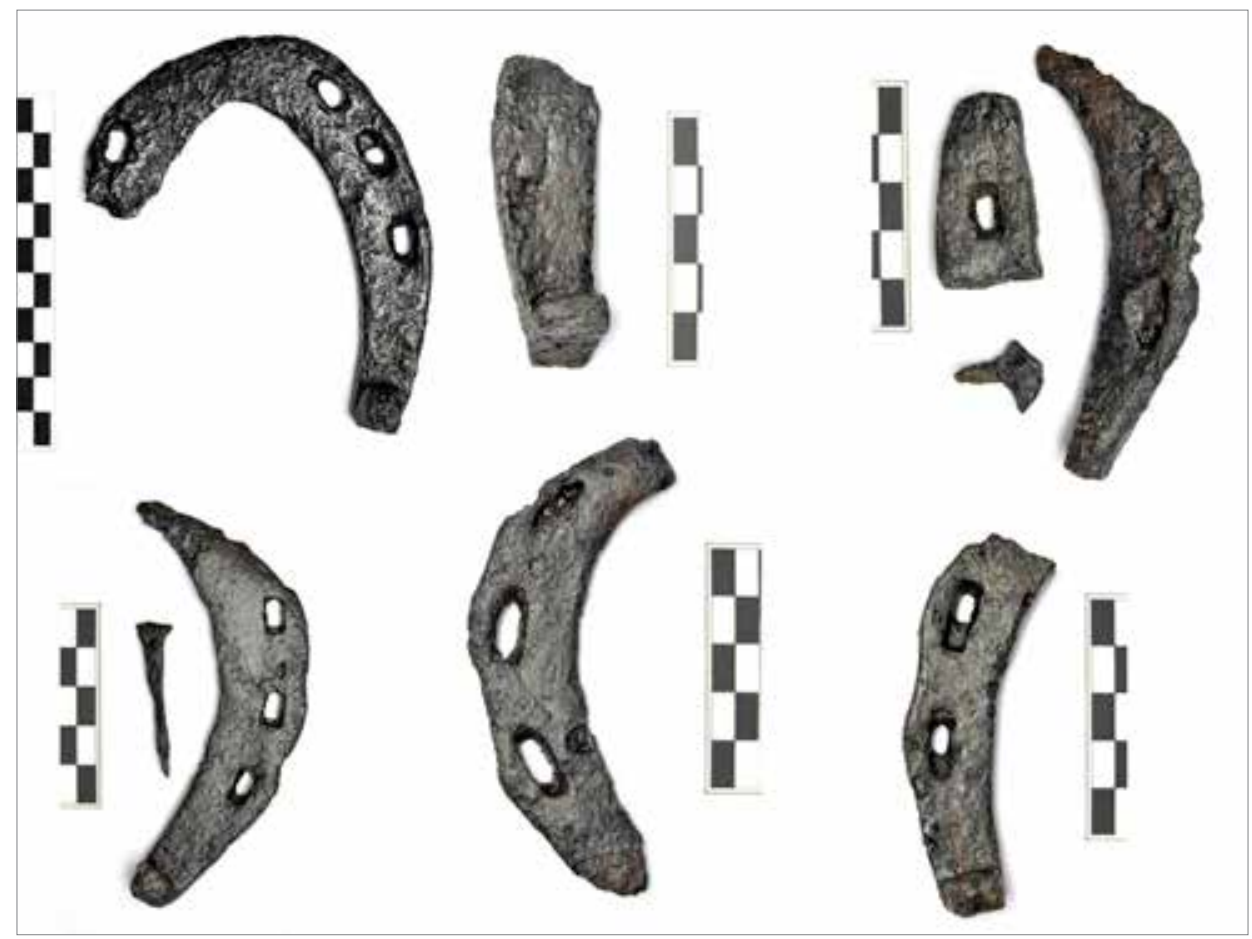

Obr. 28. Zámeček, k. ú. Stráž. Výběr z podkov nalezených v objektu opevnění. Foto M. Zemánková (ZČM v Plzni), 2018, upravil P. Sokol.

Abb. 28. Schlössl, Katastergebiet Stráž. Auswahl an im Befestigungsobjekt gefundenen Hufeisen. Foto M. Zemánková (Westböhmisches Museum in Pilsen), 2018, bearbeitet von P. Sokol. 


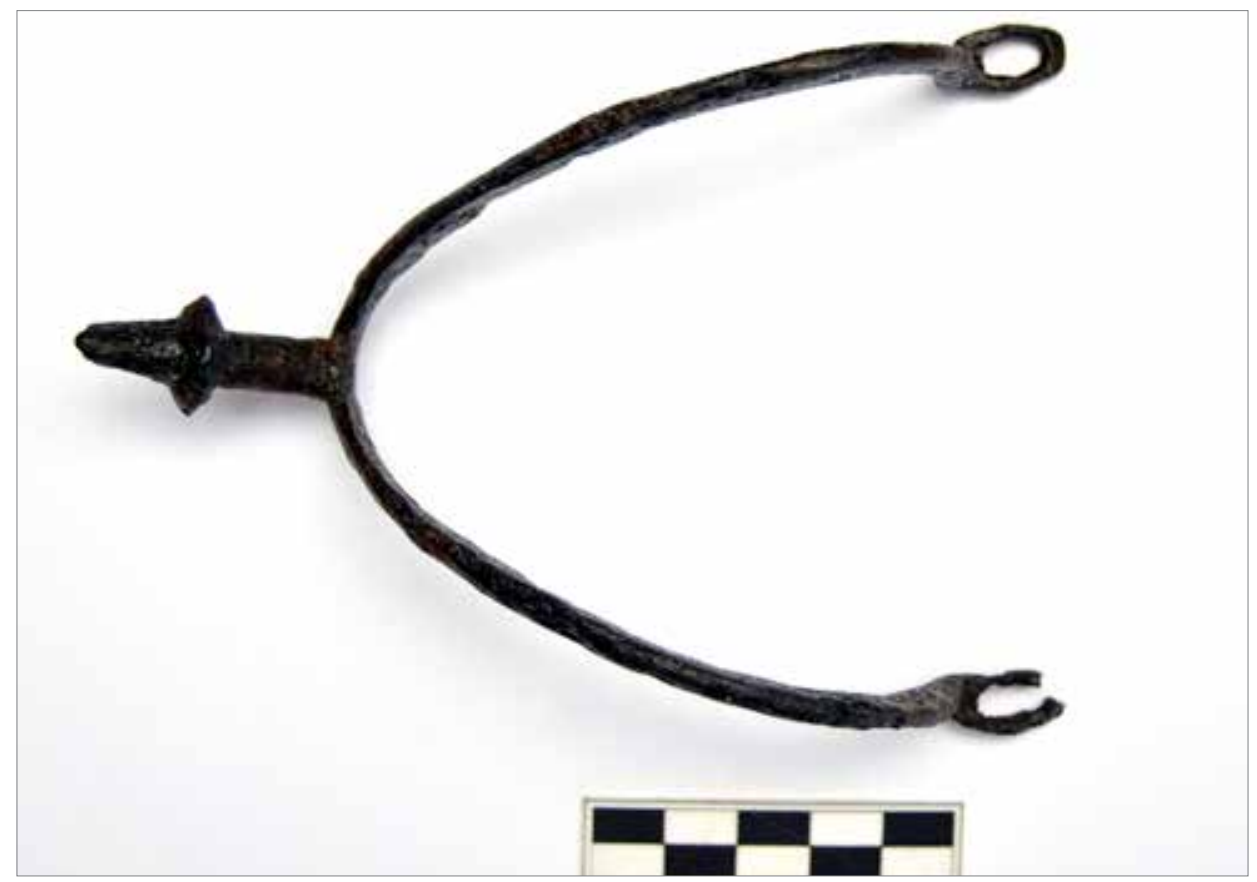

Obr. 29. Zámeček, k. ú. Stráž. Ostruha nalezená na vnějším východním valu. Foto M. Zemánková (ZČM v Plzni), 2018. Abb. 29. Schlössl, Katastergebiet Stráž. Am östlichen Außenwall gefundener Sporn. Foto M. Zemánková (Westböhmisches Museum in Pilsen), 2018.

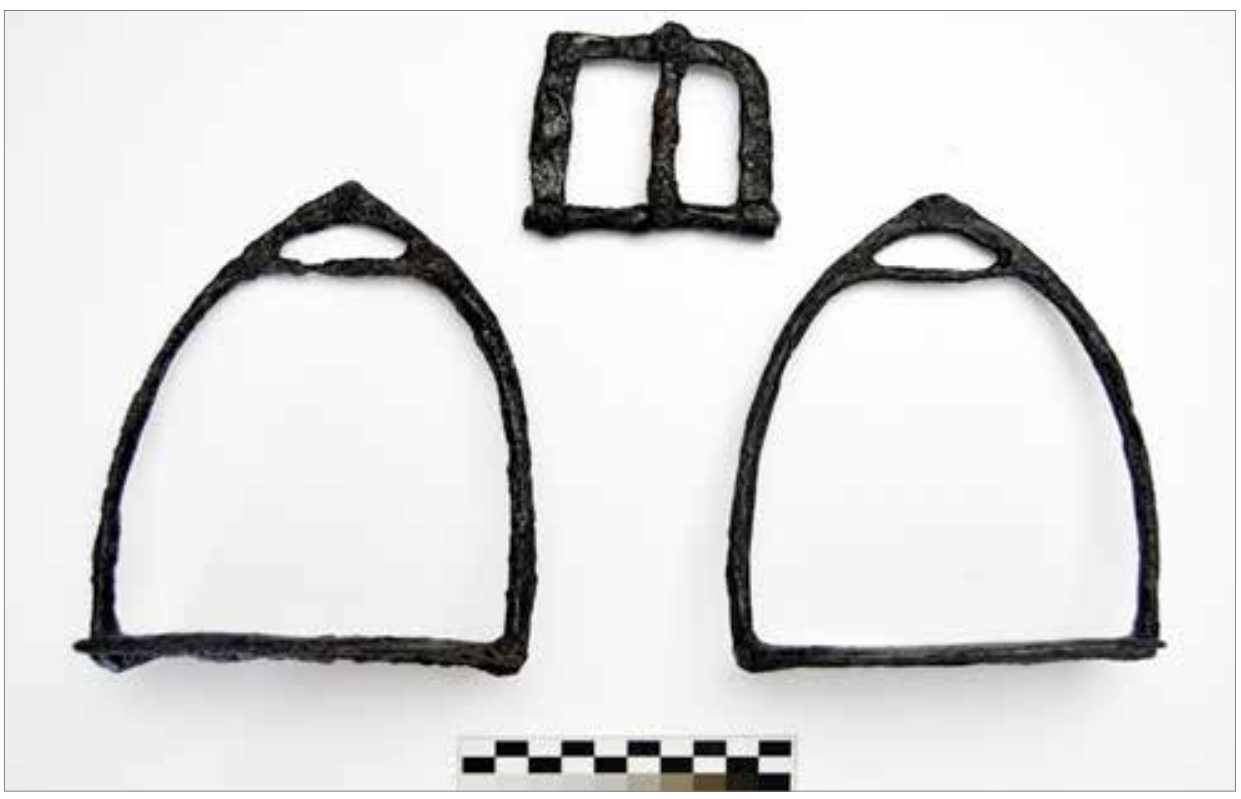

Obr. 30. Zámeček, k. ú. Stráž. Pár třmenů a přezka nalezené v místě sondy T. Foto M. Zemánková (ZČM v Plzni), 2018. Abb. 30. Schlössl, Katastergebiet Stráž. An der Stelle von Sondierschnitt T gefundenes Steigbügelpaar und Schnalle. Foto M. Zemánková (Westböhmisches Museum in Pilsen), 2018. 


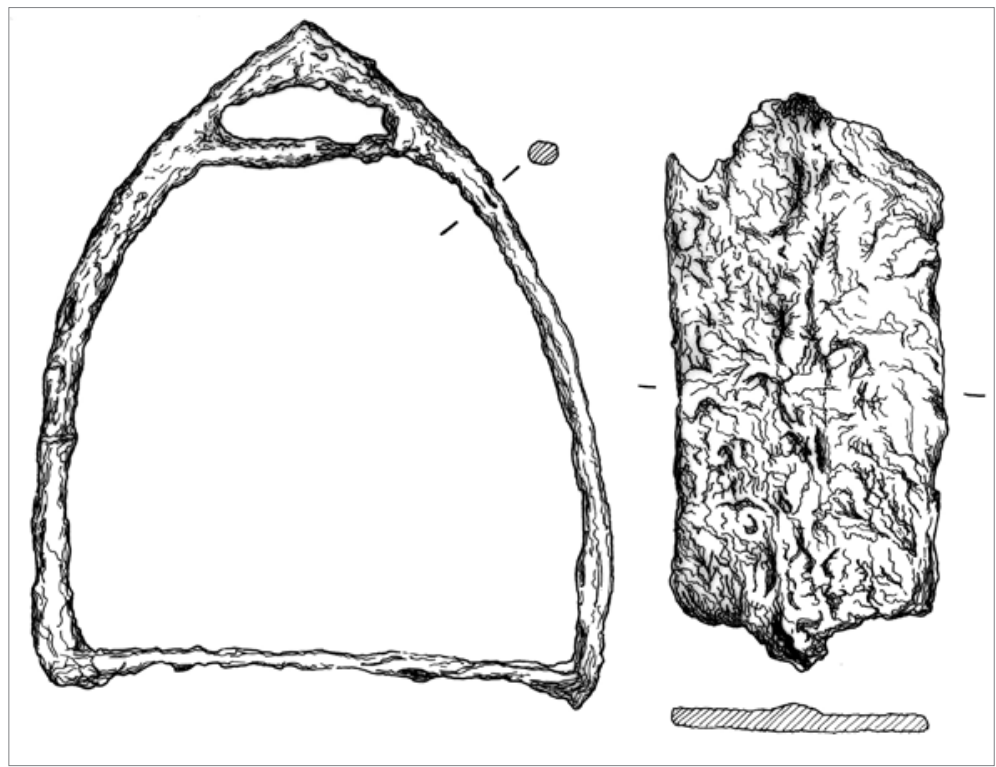

Obr. 31. Zámeček, k. ú. Stráž. Jeden z třmenů. Kresba I. Šlechtová (ZČM v Plzni), 2019. Abb. 31. Schlössl, Katastergebiet Stráž. Einer der Steigbügel. Zeichnung I. Šlechtová (Westböhmisches Museum in Pilsen), 2019.

vrcholek valu a absence prostoru pro střelce na koruně valu. Diskutabilní by byl i samotný účel a smysl takového osamoceného objektu v otevřené krajině. Stejně tak chyběly jakékoli doklady raně novověkého využití. Interpretaci neodpovídala ani existence názvů „U Zámečku“ a „Nad Zámečkem“ objevujících se pro okolní pozemky již v roce 1580 (Procházka-Úlovec 1991, 308).

Výzkum, jak již bylo uvedeno, uvedenou hypotézu nepotvrdil. Nálezy naopak jednoznačně potvrdily středověké využití objektu. Odkryté situace nenasvědčují - nejmarkantněji v sondě $\mathrm{T}$ - pozdějším zásahům a úpravám, situace $\mathrm{v}$ sondě $\mathrm{V}$ nepřinesla žádné doklady o konstrukci zdánlivých střeleckých pozic na koruně valu, do dosažené hloubky ani doklady o druhotné úpravě valu. Sondáží, a co je ještě důležitější, ani plošně výrazně rozsáhlejším detektorovým průzkumem (viz výše) nebyly získány nálezy, které lze spojit s existencí raně novověkého polního opevnění. Ani známé starší nálezy z lokality nic takového neobsahují. Úvahy směřující $\mathrm{k}$ interpretaci se tedy musely ubírat jiným směrem.

Název Zámeček ukazuje na pojmenování objektu, u kterého již nebyl znám původní účel, pouze je jím reflektována existence opevnění. Charakter opevnění a jeho umístění v rovinaté krajině a v těsné blízkosti dálkové cesty neodpovídá ničemu, co je známé z doby, do které je objekt datován archeologickými nálezy (hrad, hradiště, dvorec, refugium). Vzhledem k blízkosti a časnější existenci Přimdy musela být funkce Zámečku jiná než u Přimdy a tyto funkce si nemohly konkurovat. Funkce opevnění byla zcela jistě pevně svázána s těsnou polohou při zemské stezce (obr. 32). Charakter objektu se vyznačuje důrazem na pasivní ochranu vnitřního prostoru, absencí zděné zástavby, mohutností prvků opevnění odpovídající hradišti, ovšem pro mnohem menší a pravidelně vymezenou plochu. Vyjdeme-li z uvedeného a současně i z absence dokladů mladšího využití a úprav objektu a ze vzájemného vizuálního kontaktu opevnění s hradem Přimda, docházíme k zjištění, že opevnění Zámeček svým umístěním i předpokládanou funkcí velmi dobře odpovídá strážnici nebo celnici, případně tzv. knížecí stanici (spojení těchto funkcí v rámci jednoho objektu je nejisté, ovšem v tomto případě pravděpodobné), k ochraně cesty a cestujících u zemských stezek. O podobě těchto objektů pro období 12.-13. století není nic 


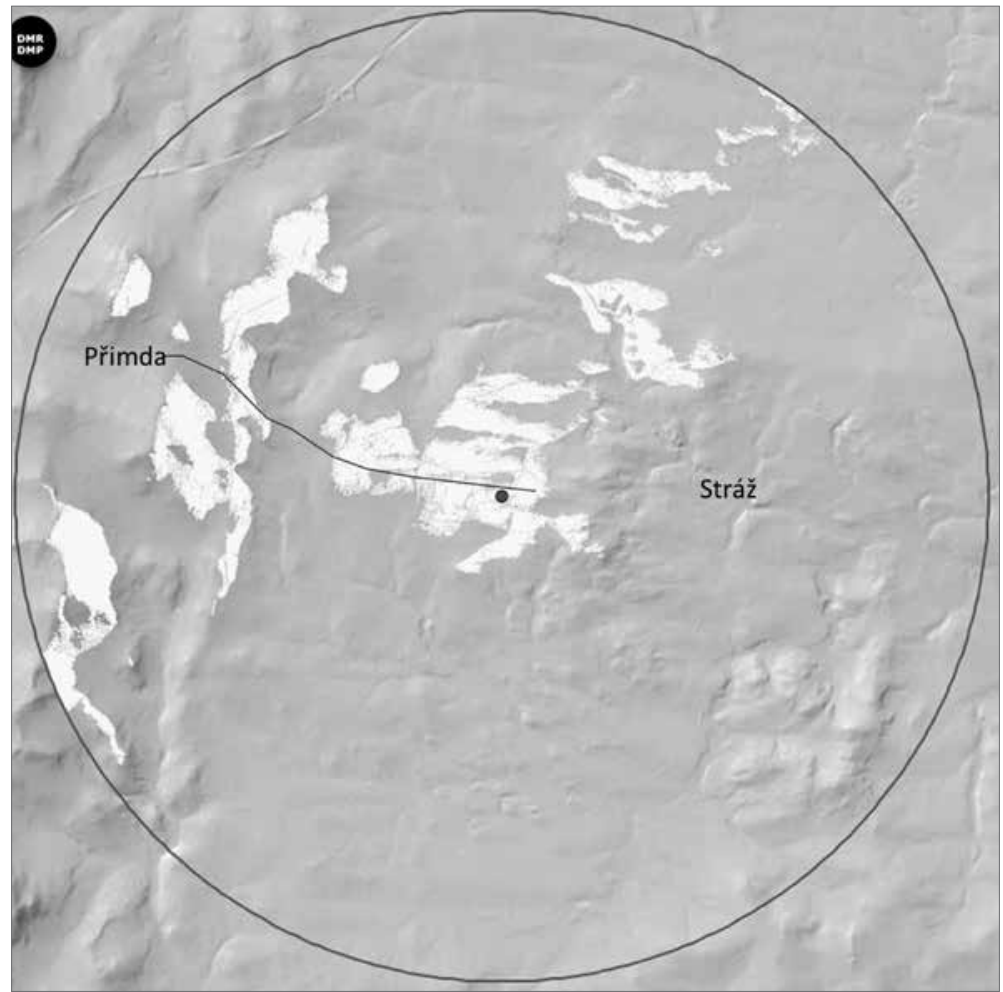

Obr. 32. Zámeček, k. ú. Stráž. Plochy viditelné z úrovně $2 \mathrm{~m}$ nad současnou úrovní koruny severozápadního nároží objektu a vyznačení průběhu zemské stezky v úseku mezi Přimdou a Zámečkem. Zdroj Analýza výškopisu, upravil P. Sokol.

Abb. 32. Schlössl, Katastergebiet Stráž. Aus einer Höhe von $2 \mathrm{~m}$ über dem derzeitigen Höhenniveau der Krone der nordwestlichen Ecke des Objektes sichtbare Flächen und Kennzeichnung des Verlaufs des Landespfades im Abschnitt zwischen Přimda und dem Schlössl. Quelle Analyse der Höhendarstellung, bearbeitet von P. Sokol.

známo, mohutnost opevnění Zámečku a míra dochování se zdají při této interpretaci překvapivé, zejména pod vlivem apriorního očekávání reliktů spíše nevýrazných a nepravidelných.

V literatuře se udává budování knížecích stanic na hlavních cestách blízko pomezního hvozdu u zemských bran (Minátová 1979, 27), podle I. Vávry byly raně středověké celnice budovány v místech vstupu na osídlené území $(1973,72)$. Obojí charakteristika nápadně odpovídá Zámečku. Tyto stanice měly mít ochranný a obranný účel včetně dozoru nad bezpečností cesty, jejich ztotožnění se strážnicemi se tedy nabízí, používání terminologie však není v tomto směru jednoznačné. Strážnice patřily k systému zajištění vstupu do země, podle F. Roubíka chránily zemské brány, v jejichž blízkosti se nacházely i celnice (Roubík 1938, 8-9). Strážnice s celnicemi, poskytování ochrany obchodníkům s možností doprovodu a asi i s možností kovárny a hospody spojuje do jednoho celku J. K. Hraše $(1885,15)$.

Ze Zámečku je dobře pozorovatelná většina úseku zemské stezky směrem k Přimdě, s hradem je opevnění ve vizuálním kontaktu. Poloha je daná jednak nutností přehledu o úseku cesty k hranici, úzkou vazbou na cestu samotnou a dostupností, což by mohlo představovat ve vyvýšené poloze problém, včetně vazby na cestu, která se v prostoru hřebene mezi Zámečkem a Stráží větví, a stanice by tak ztrácela na efektivitě. 


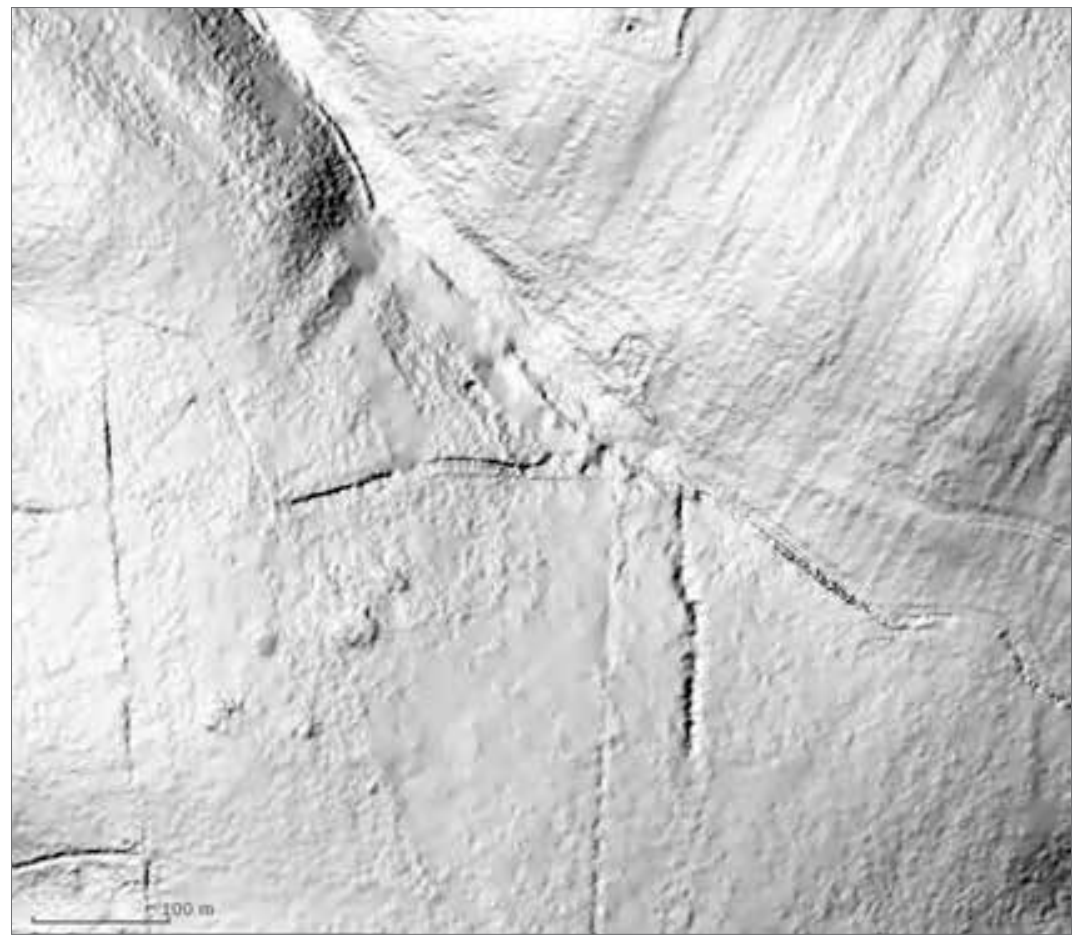

Obr. 33. Kozlov, k. ú. Ošelín, okr. Tachov. Přibližně uprostřed zničený objekt čtvercového půdorysu patrný dosud na stínovaném reliéfu, z-factor 10, data 5G. Zdroj Analýza výškopisu.

Abb. 33. Kozlov, Katastergebiet Ošelín, Bezirk Tachov. Ungefähr in der Mitte auf einem Schattenrelief bislang sichtbares zerstörtes Objekt mit quadratischem Grundriss, Z-Faktor 10, 5G-Daten. Quelle Analyse der Höhendarstellung.

Existenci strážnice podporuje i název Stráže, která vznikla zhruba ve stejné době nebo o něco později než Zámeček. Samo jméno tak mohlo reflektovat existenci opevnění západně od města.

O strážnici u Stráže píše i J. K. Hraše, který ji však bez udání důvodu situuje na hřeben $1 \mathrm{~km}$ západně od Stráže (Hraše 1885, 117). Došlo tak k záměně strážnice/celnice se strážištěm.

Systém ochrany hranic v raném středověku popsaný P. Chocem $(1967,289)$ a P. Šídou $(2005,859)$ nelze považovat za model uplatnitelný obecně. Při aplikaci na hranici v místech jejího přechodu zemskou stezkou, zvanou později Norimberská, byla blíže k hranici zdejší dominanta Přimda a teprve za ní směrem do vnitrozemí vznikla následně strážnice/celnice.

Strážnice měly hlídat zemské stezky, bránit zemi před průniky menších oddílů nepřátel, bránit podloudnému obchodu a varovat zemi v př́ípadě většího nebezpečí (Šída 2005, 590). Početnost a vybavení strážných posádek neznáme (Šída 2005, 591). Zámeček u Stráže umožňuje učinit si alespoň hrubou představu o síle takové strážní posádky - zde ji vzhledem k velikosti vnitřní plochy a s předpokladem nějaké zástavby a potřeby volného prostoru nejen pro posádku, ale i pro cestující odhadujeme na maximálně několik desítek osob.

Více informací máme o strážnicích vrcholného středověku, kterým byla věnována detailnější pozornost (Fišera 2002; Plaček 1990; Kouřil-Žáček 1989). Vznik většiny vrcholně středověkých strážnic v Čechách klade Fišera do 13. století. Tyto strážnice disponovaly pouze dřevěnou či hrázděnou zástavbou. Charakteristická je pro ně i absence hospodářského zázemí a situování k cestám (Fišera 2002, 49). Vrcholně středověké strážnice jsou chápány jako objekty 


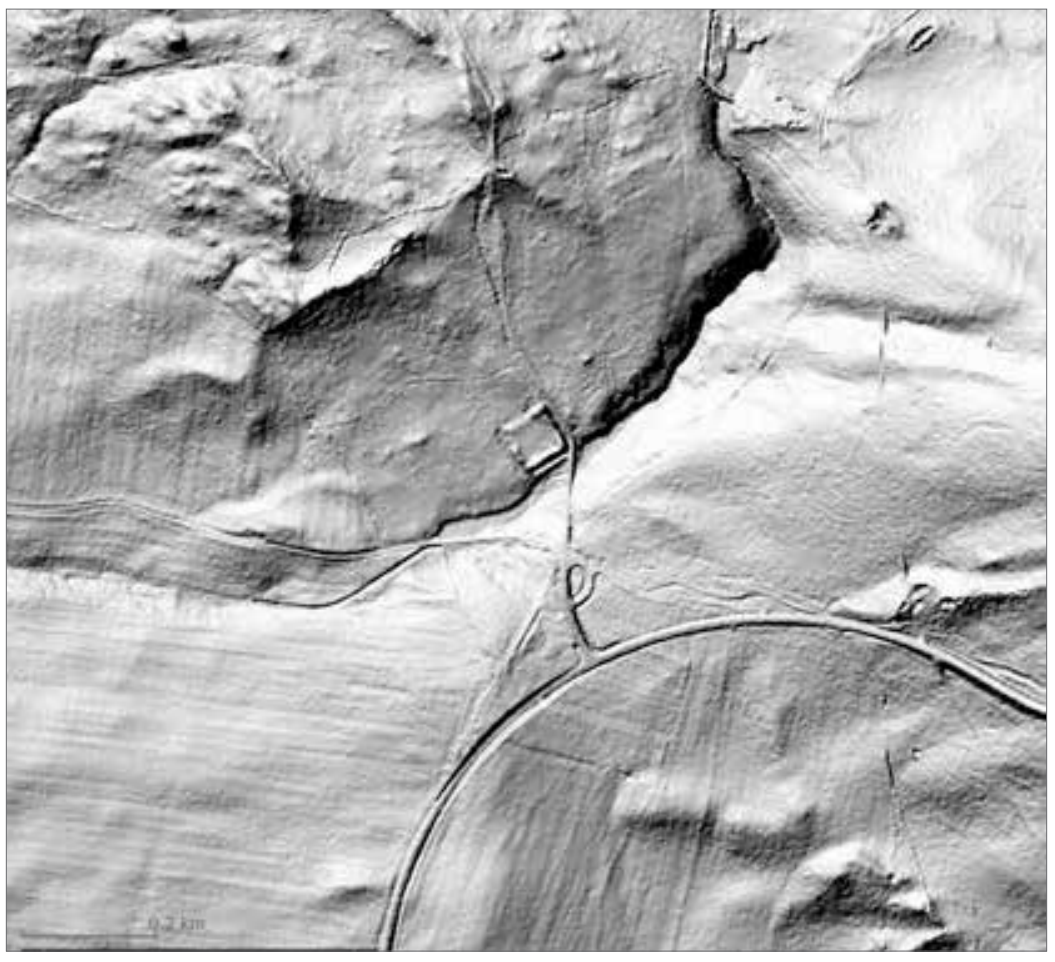

Obr. 34. Kučeř, okr. Písek. Uprostřed objekt čtvercového půdorysu na stínovaném reliéfu, z-factor 10, data 5G. Zdroj Analýza výškopisu.

Abb. 34. Kučeř, Bezirk Písek. In der Mitte Objekt mit quadratischem Grundriss auf einem Schattenrelief, Z-Faktor 10, 5G-Daten. Quelle Analyse der Höhendarstellung.

podobající se tvrzi či menšímu hradu, zatímco strážiště jen jako polohy v místech rozhledu, upravené pro přechodné obývání, s možností ohňové signalizace (Fišera 2002, 46). Jejich využití, indikované charakteristickými jmény Stráž, Strážiště, Varta apod. (k tomu napřr. Šída 2005, 591-592), je doloženo často až pro novověk. Strážnice, obdobně jako Zámeček byly naopak situovány v nižších polohách blíže ke komunikaci, kterou měly střežit. Posádky nebyly početné, ale mohly zajištovat doprovod či se podílet na ostraze pomezí. Spolu se strážišti tvořily zřejmě jeden systém. U vrcholně středověkých strážnic je pravděpodobná záměna s hrady nebo tvrzemi. Vztah strážnice a celnice není jasný (Fišera 2002, 46).

V praxi zřejmě řada hradů, kterým je přisuzována strážní funkce, nebyla přímo tím objektem, který konkrétní úsek cesty střežil. Tyto hrady je nutné vnímat spíše jako opěrné body, jež poskytovaly oporu a ochranu těm objektům, které zajišt'ovaly praktickou kontrolu cest - strážnicím a celnicím ( $\mathrm{k}$ tomu též Plaček 1990, 209) a jejichž posádky mohly zasáhnout v případě většího konfliktu nebo nebezpečí. Toto byl velmi pravděpodobně i případ hradu Přimda a strážnice/ celnice Zámeček u Stráže.

V období 12. století se v úseku od hranice po dnešní Stráž zformoval průběh zemské stezky se zeměpanskými oporami Přimdou a Zámečkem (k tomu též Široký-Nováček 1998, 66-67). Vzhledem k jejich vzájemné chronologii můžeme předpokládat následující vývoj zajištění příhraničního úseku zemské cesty: Po zbudování zeměpanského hradu vysunutého do blízkosti vlastní hranice jakožto mocenské výspy a viditelného symbolu vlády a územních nároků českého knížete (Sokol 2014a, 20) došlo následně k dobudování základního funkčního systému, tedy 


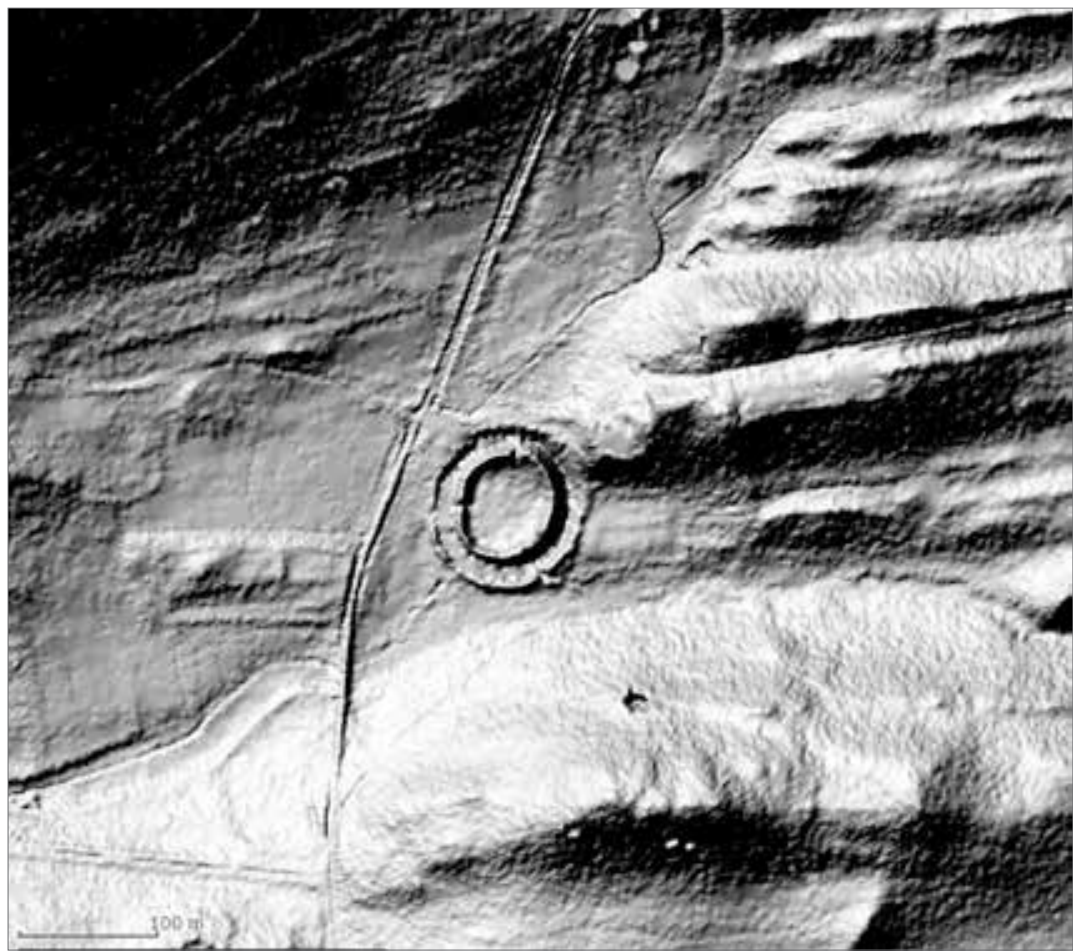

Obr. 35. Obora (Dvorce), k. ú. Dobříš, okr. Příbram. Kruhový objekt na stínovaném reliéfu, z-factor 10 , data 5G. Zdroj Analýza výškopisu.

Abb. 35. Obora (Dvorce), Katastergebiet Dobříš, Bezirk Př́ibram. Kreisförmiges Objekt auf einem Schattenrelief, Z-Faktor 10, 5G-Daten. Quelle Analyse der Höhendarstellung.

k doplnění objektu se specifickou funkcí, který je pro svůj účel i pro svou menší obranyschopnost zasunutý do týlu pohraničního pásma až za vlastní pomezní hrad a současně se nachází v jeho ochranném dosahu i v dohledu. Předpokládat můžeme doplnění sítí strážišt' na vybraných výšinných polohách ve vzájemném dohledu pro rychlé předávání signálů směrem do vnitrozemí na způsob systému včasného varování (k tomu např. Šída 2005, 590, 591).?

Na prŕíhraničním úseku přimdské stezky tak vzniklo a určilo její trasu v 12.-13. století několik základních bodů. Směrem od hranic to byl vlastní hraniční přechod, který je kladen do okolí Sv. Kateřiny (Hraše 1885, 62) či Rozvadova (Vávra 1973, 31, 35; Široký-Nováček 1998, 65). Následoval pomezní zeměpanský hrad Přimda, existující ve své románské podobě po roce 1126 , ve 12. století zatím zrrejmě bez rozvinutého podhradí v sedle hřebene. Poté následovala zřejmě v druhé polovině 12 . nebo na přelomu 12. a 13. století v týlu zbudovaná strážnice a zřejmě již tehdy nebo někdy od první poloviny 13 . století ještě o zhruba $2 \mathrm{~km}$ dále na východ situovaná Stráž.

Hrad Přimda se nacházel asi v polovině úseku od Sv. Kateřiny po Zámeček u Stráže. Celý tento úsek od Sv. Kateřiny po Zámeček u Stráže široký zhruba 11 km (od Rozvadova $14 \mathrm{~km}$ ) tak tvoří pro 12. století minimální šiřku pohraničního pásma, které bylo předmětem ochrany a strážních povinností.

7 Takovéto strážiště využívané v několika obdobích včetně 13. století je v regionu doloženo např. na vrchu Rozsocha 10 km jihovýchodně od Zámečku (Bašta 1987, 47-48), předpokládat ho můžeme i přímo na hřebeni nad opevněním Zámeček. Obecně je třeba zvažovat, zda doklady středověkého osídlení ve vyvýšených, exponovaných a plošně omezených polohách (pro západní Čechy typicky polohy s osídlením chamské kultury) nemohou dokládat existenci strážišt'. 


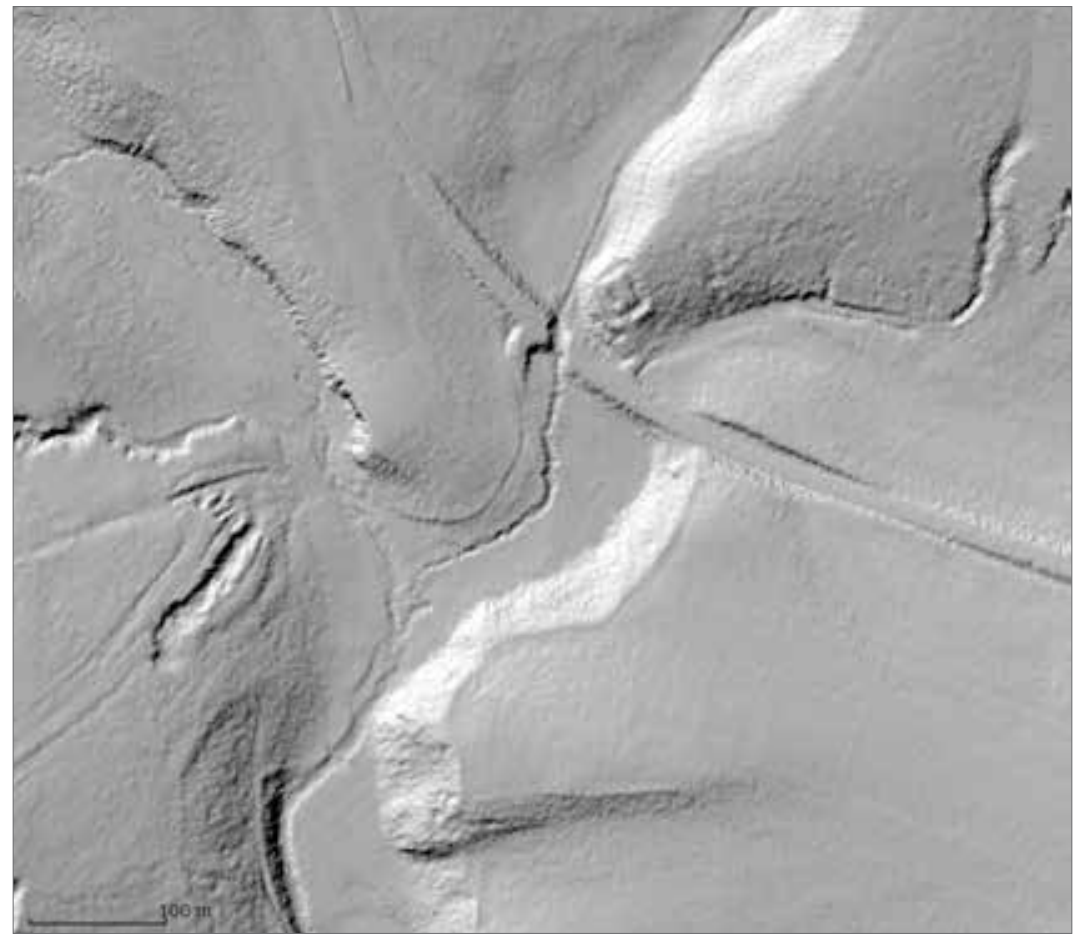

Obr. 36. Zámeček, k. ú. Černošín, okr. Tachov. V pravém horním segmentu objekt obdélného půdorysu na stínovaném reliéfu, data 5G. Zdroj Analýza výškopisu.

Abb. 36. Schlössl, Katastergebiet Černošín, Bezirk Tachov. Im rechten oberen Segment Objekt mit rechteckigem Grundriss auf einem Schattenrelief, 5G-Daten. Quelle Analyse der Höhendarstellung.

Zánik Zámečku v 13. (14.?) století může naznačovat rozvolňování dosavadního systému ochrany cesty. Proces mohl souviset s novou celnicí v Přimdě, vzniklou snad již ve 13. století (Široký-Nováček 1998, 64, 67; celní výsady pro Přimdu 1331, Minátová 1979, 29). Současně během 13. století vzrůstal význam švamberského Boru na úkor komorní Stráže (Vávra 1973, 63) a měnila se i trasa cesty, která byla vedena i přes Bor. Zřejmě z těchto důvodů celnice/strážnice u Stráže zanikla. Vzájemná posloupnost těchto událostí je však pouze hypotetická, zejména s ohledem na zvažovaný vznik přimdské celnice již ve 13. století.

V souvislosti s uvedenou interpretací se přirozeně nabízí předpoklad, že i při dalších cestách v blízkosti hranic byly budovány obdobné objekty, z nichž některé se mohly dochovat do současnosti pod ,pláštěm“ jiné, třeba i problematické interpretace. Nelze přitom pominout možnost typologické variability takových objektů. Lze očekávat, že do dnešní doby se dochovalo jen minimum takovýchto objektů, zejména byly-li situovány v dobře dostupných a využitelných polohách nebo byly-li vystaveny silnějšímu působení eroze. Obtíže při hledání analogických lokalit a objektů zvětšuje navíc skutečnost, že strážnice/celnice nepatří mezi frekventované předměty bádání a i ty objekty, které se dochovaly, mohou být interpretovány zcela jinak. Zde představujeme pouze několik možných analogií $\mathrm{k}$ Zámečku u Stráže, jejichž platnost by si vyžádala důslednější ověření:

Kozlov, k. ú. Ošelín, okr. Tachov. Tato lokalita byla koncem 70. let 20. století zcela zničena, předtím z ní však byly získány nálezy (zřejmě středověké) a registrovány snad i zbytky zdiva. Objekt s obdélným nebo čtvercovým jádrem byl opevněn dvojitým valem a př́kopem (obr. 33). Celkové vnější rozměry jsou udávány $100 \times 80 \mathrm{~m}$, pro vnitřní plochu asi $25 \times 30 \mathrm{~m}$. Objekt 


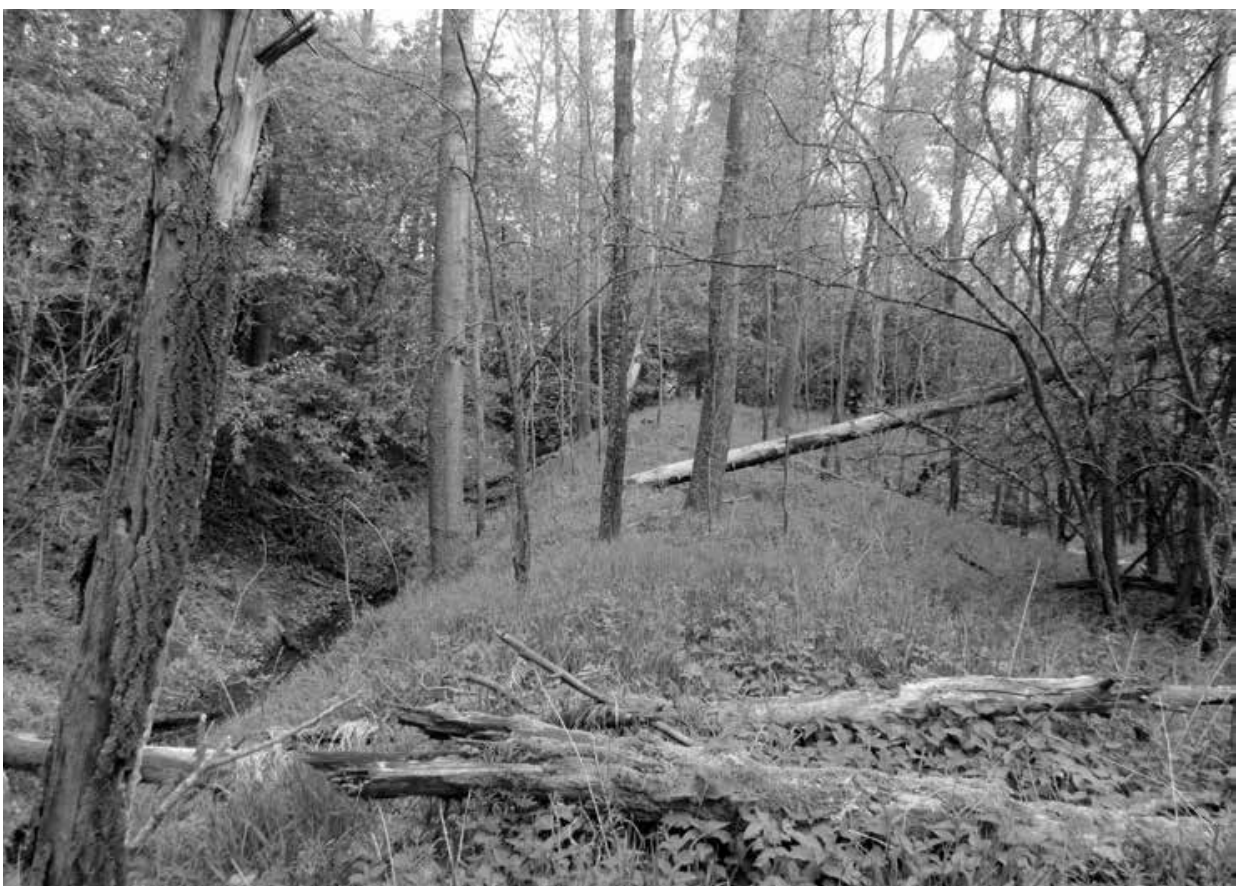

Obr. 37. Zámeček, k. ú. Stráž. Východní vnější val od jihu. Foto P. Sokol, 2016.

Abb. 37. Schlössl, Katastergebiet Stráž. Östlicher Außenwall von Süden. Foto P. Sokol, 2016.

je dosud považován za tvrziště (Sedláček 1905, 136; Procházka-Úlovec 1988, 62-63) nebo za opevnění z třicetileté války (Bělohlávek a kol. 1985, 249-250). Za možnou obdobu Zámečku ji považuje J. Hajšman $(2001,54)$. Nápadná je skutečnost, že stejně jako Zámeček u Stráže i Kozlov leží na trase zemské stezky, tentokráte tachovské pro 11.-12. století v úseku mezi Kladruby a Tachovem a v blízkosti vsí spojovaných s Chody (Vávra 1973, 55, 64; Minátová 1979, 28-29, 31; Široký-Nováček 1998, 65-66).

Kučeř, okr. Písek. Lokalita považovaná za laténské čtyřúhelníkové valy (Waldhauser 1992, 550), téměř čtvercového půdorysu $65 \times 68 \mathrm{~m}$, v rovinaté poloze, objekt má vyvýšená nároží (obr. 34). Na základě analýzy viditelnosti (Analýza výškopisu) je u Kučeře rozhled především ve směru západ-východ, zejména k západní straně, tedy ve směru předpokládané cesty z Milevska do údolí Vltavy v blízkosti pozdějšího hradu Zvíkova (k lokalitě Fröhlich 1971; 1973; 1997, 68-69; Fröhlich-Michálek 1978, 113; Památkový katalog). Dosavadní nálezy pochází pouze z 11.-12. (případně 12.-13.) století.

Obora (Dvorce), k. ú. Dobřríš, okr. Příbram. Objekt téměř kruhového půdorysu, s mohutným valem a vodním příkopem a vnějším valem, o celkovém průměru přes $100 \mathrm{~m}$ (obr. 35). Hypoteticky je objekt datován do konce 12. nebo první poloviny 13. století. Skutečná funkce není známa, uvažuje se o útočišti, opevněném rezidenčním dvoru nebo o nedostavěném opevněném sídle (Svoboda a kol. 1998, 158). Pro refugiální účely se objekt nachází v netypické a nevýhodné poloze, rovněž jako dvůr se zdá objekt netypický, stejně jako prrípadné opevněné sídlo, což je samo o sobě značně vágní pojem.

Zámeček, k. ú. Černošín, okr. Tachov. Objekt spíše oválného než obdélného půdorysu o rozměrech ca $30 \times 20 \mathrm{~m}$, obklopený př́kopem, na jižní straně i valem, umístěný na úpatí nízkého hřebene (obr. 36) v těsné blízkosti zemské stezky. Prozatím bez nálezů (Procházka-Úlovec 1991, 287-288). 
Uvedené př́klady (bez nároků na jejich komplexnost či reprezentativnost) i přes svůj nevelký počet ukazují možnou variabilitu objektů, u nichž může nebo by měla být zvažována strážní nebo i celní funkce.

V př́ípadě Zámečku je pro základní hrubou představu o vzhledu strážnice/celnice několik indicií jak z dochovaného stavu objektu, tak z nálezů získaných archeologickým výzkumem. Stanice byla umístěna na nepatrnou vyvýšeninu při okraji potoční nivy, ze dvou stran chráněnou vodotečemi a mokřadem (obr. 18). Čtvercový prostor vymezený mohutným valem a př́kopem a před ním i vnějším pásem stejných prvků menších rozměrů obsahoval blíže neurčenou dřevěnou zástavbu (s podezdívkou?), kterou můžeme předpokládat spíše po obvodu plochy. Součástí vybavenosti byla snad minimálně jedna kachlová kamna sloužící posádce, nebo ve shodě s představou o existenci hospody v rámci strážnice/celnice (Hraše 1885, 15) i cestujícím. Obojí lze pro objekty trvalého, nikoli jen jednorázového účelu předpokládat. Stejně jako hospoda nabízí se i kovárna jako nutná součást takové stanice pro zajištění potřebných součástí nástrojů, stavebního materiálu a výstroje (Hraše 1885, 15). Vnitřní strana valu mohla být zpevněna kamennou plentou nebo opěrnou zídkou. Zesílená a vyvýšená nároží vnitřního valu indikují možnost nárožních dřevěných věží, vzájemně snad spojených lehčím opevněním, případně i přístupové rampy. Zářezy v koruně valu jsou nejspíše výsledkem výkopů popisovaných A. Sedláčkem (Hajšman 2001, 50) nebo mohou souviset s recentními palebnými pozicemi. Př́ístup do stanice vedl zřejmě od severu přes prríkop spojující objekt s rybníkem, pokračoval po koruně vnějšího východního valu (obr. 37) a po mostku přes příkop do brány ve vnitřním východním valu. Vedení přístupu po koruně vnějšího východního valu naznačují i nálezy kovových předmětů (ostruhy, hřebů a zlomků podkov).

Počínaje A. Sedláčkem zmiňují badatelé napájení příkopu vodou z rybníka. Skeptický je vůči této možnosti J. Hajšman, který vychází z porovnání výškových úrovní dna př́ikopu a koruny hráze (Hajšman 2001, 51). Hladina rybníka dnes nedosahuje úrovně umožňující zaplnění př́kopu vodou a na základě konfigurace terénu a poznatků získaných výzkumem to nelze předpokládat ani pro starší období. Potřebné zvýšení hladiny o ca 3 metry by vedlo k několikanásobnému zvětšení rozsahu rybníka a k rozsáhlému zatopení východního, jižního i severního okolí Zámečku, nehledě na nutně o ca $4 \mathrm{~m}$ vyšší a tomu adekvátně delší hráz, která by potřebné zvednutí hladiny umožnila.

Mírné zavodnění přilehlého východního úseku příkopu, které je dosud pozorovatelné, nelze jednoznačně dávat do souvislosti s povrchovým propojením s rybníkem. Vlhčí charakter spodních úrovní výplně příkopu může být výsledkem i přirozeného vlhčího prostřredí nebo občasného přirozeného zavodnění.

Propojení s rybníkem tak mohlo sloužit opačnému účelu, tedy k odvádění vody z př́ikopu do rybníka, současně mohlo jít o obranný prvek v trase př́stupu. Dodatečnému vzniku by nasvědčoval odlišný charakter tohoto propojovacího příkopu od př́íkopu obvodového.

\section{Chodská stopa}

Název Chodové je historicky doložen pro privilegované obyvatele některých vsí na česko-bavorském pomezí střežící zemskou hranici (Maur 1984, 11). Podle starší literatury měly povinnosti Chodů vojenský charakter a byly vázány na zemské stezky. Chodové byli ztotožněni se strážemi zemských stezek u hranic objevujícími se v pramenech 11.-12. století (Maur 1984, 11-12; pro 11. století počítá s Chody Vávra 1973, 34). Jako zvláštní strážce zemských hranic ve staré době Chody uvádí F. Roubík a mezi jejich povinnosti řadí dohlížení na neporušenost zemských hranic, provázení obchodníků k nejbližší celnici z důvodů bezpečnosti i zaplacení cla (Roubík 1938, 8).

Strážní služba Chodů byla zohledněna v privilegiích od 14., respektive snad již od 12. století (Birner 1976, 173). Prameny z 15. a 16. století pro Chody udávají již zčásti odlišné úkoly, stále však včetně střežení hranice a poskytování ozbrojeného doprovodu obchodníkům (Maur 1984, 12-13). H. Minátová bez bližšího časového určení udává mezi úkoly Chodů celní službu, 
doprovázení obchodníků mezi celními stanicemi, při válečné akci pak blokaci cest a varování obyvatelstva $(1979,31)$.

Počátky strážní služby Chodů lze klást nejspíše do 12. století, kdy se konsolidovaly trasy zemských stezek a kdy bylo třeba v důsledku oboustranné kolonizace pohraničního lesa přesněji vymezit a důsledněji střežit průběh hranice (Maur 1984, 13). Pro Stráž jsou uvedeni poprvé v privilegiu Jana Lucemburského z roku 1331 (Kuča 2008, 84; Baštář 1973, 1-2).

Plnili-li Chodové své strážní funkce ve smyslu ostrahy hranic a zemské stezky v období konce 12. a průběhu 13. století, pak Zámeček u Stráže představuje konkrétní lokalitu, kterou lze s jejich působením spojit. Nejspíše právě Chodové by tvořili posádku této stanice s působností vztahující se pravděpodobně na úsek zemské cesty směrem $\mathrm{k}$ Přimdě a dále k zemské hranici.

\section{Závěr}

Důvodem dosavadních nejistých interpretací Zámečku byly atypické rysy objektu ve vztahu k tradičně zvažovaným typům opevněných lokalit pro období určené staršími nálezy na přelom 12. a 13. století. Během výzkumu byl získán soubor zlomků kuchyňské i stolní keramiky i komorových kachlů a soubor kovových předmětů obsahující především součásti nástrojů a jezdecké výstroje. Odkryta byla část spálené dřevěné konstrukce, naopak nebyla prokázána zděná zástavba.

Vzhledem k pozoruhodné shodě datování keramických i kovových předmětů, dendrochronologickému i radiokarbonovému datování nelze pochybovat o existenci objektu v intervalu od druhé poloviny 12. do 13. století. Vznik objektu lze nejpravděpodobněji klást do konce 12. či počátku 13. století, jeho zánik (nejspíše požárem) pak do 13. století (snad do jeho druhé čtvrtiny). Mladší využití nebo úpravy objektu nebyly prokázány, vzhledem k charakteru keramických nálezů zůstává však možnost delšího trvání existence objektu nebo jeho využívání po př́ípadném zániku (první polovina 14. století?).

Charakteristické rysy objektu, jako jsou výrazná mohutnost a pravidelnost opevnění, obranný, vojenský charakter, ale i relativně menší rozměry, absence zděné zástavby a především umístění objektu do nížinné polohy, činily dosud spolu s dosavadním datováním keramických nálezů interpretační problémy a při snaze o aplikaci základních typů opevněných lokalit středověku se Zámeček jevil jako objekt zcela atypický.

Kromě vlastních archeologických nálezů a jejich datování se jako stěžejní pro lokalitu ukázal průběh dnes již zaniklé cesty, kdysi jedné ze dvou větví zemské (Norimberské) stezky. Trasa této přimdské větve vedla v těsné blízkosti Zámečku, který byl vůči ní ve strategickém umístění (bezprostřední kontrola daného úseku cesty, přehled o průběhu směrem k Přimdě, vizuální kontakt s hradem Přrimda).

Na základě výše zmíněných ,atypických“ znaků, specifického umístění, vazby na důležitou komunikaci v blízkosti zemské hranice i archeologických nálezů a jejich datování považujeme Zámeček u Stráže za stanici při zemské stezce (strážnici nebo celnici, nejspíše s funkcemi obojího) zbudovanou v zájmu zeměpána jako jeden $\mathrm{z}$ opěrných bodů ve strategickém úseku zemské stezky. Nebudeme-li rozporovat existenci a pojetí strážní služby Chodů v uvedeném období, pak s velkou pravděpodobností Zámeček představuje konkrétní objekt spojený s touto specifickou skupinou obyvatel jihozápadního příhraničí Čech.

Domníváme se, že k interpretaci účelu Zámečku lze najít analogie v některých dosud nejednoznačně interpretovaných objektech z přibližně stejného období. Prověření a případné přehodnocení by si zasloužily lokality dosud problematicky interpretované $\mathrm{z}$ hlediska tradičně uplatňované typologie opevněných objektů, včetně těch, u kterých byly středověké nálezy považovány za doklad druhotného využití.

V souvislosti s původní pracovní hypotézou o raně novověkém původu a vojenském účelu objektu a s možností jiné datace, než k jaké jsme dospěli v průběhu výzkumu, konstatujeme, že jen těžko si lze představit důslednější korespondenci datací objektu stanovených na základě známých nálezů, metod absolutního datování, prostorového i historického kontextu, to vše při 
absenci dokladů pro dataci odlišnou. Limitů plošně malého odkryvu jsme si vědomi, nicméně zůstává skutečností, že zatím ani jediný nález, ani jedna zjištěná situace nenaznačuje jiný než stř̌edověký původ, ani druhotné úpravy včetně přemístění staršího materiálu.

Formální znaky objektu, které se zdají být typické spíše pro raně novověká polní opevnění, nemohou být samy o sobě důvodem k odmítnutí staršího původu. Zejména pokud o dané problematice je známo jen velmi málo a jednoznačné analogie se nedochovaly nebo nebyly dosud rozpoznány.

V př́ípadě interpretace Zámečku jako strážnice/celnice z přelomu 12. a 13. století do sebe zapadá vše od starších i nových nálezů, absolutního datování odebraných vzorků, historického a prostorového kontextu až po absenci nálezů a situací dokládajících mladší než středověké využití. Předmětem diskuse může být doba zániku objektu, případně jeho následné využívání. Naopak u interpretace jako raně novověkého polního opevnění stojíme před řadou komplikací a nelogičností, zejména ve vztahu k výsledkům dosavadního výzkumu.

Tím ovšem není řečeno, že prrípadné nálezy budoucího výzkumu tuto (nebo jinou) možnost nevrátí do hry. Za současného stavu poznání jsme však nuceni se přiklonit k interpretaci, kterou zde předkládáme.

Článek je výstupem výzkumného cíle Archeologie (dílčí cíl Terénní identifikace a dokumentace vybraných archeologických lokalit a opomíjených archeologických památek v krajině za pomoci nových dokumentačních metod), financovaného z institucionální podpory Ministerstva kultury na dlouhodobý koncepční rozvoj výzkumné organizace NPÚ.

\section{Literatura}

BAŠTA, J., 1987: K otázce poznání a interpretace strážišt'. In: Ročenka Klubu Augusta Sedláčka, 47-49. Plzeň.

BAŠTÁŘ, J., 1973: Dějiny města Stráže u Tachova, Sborník Okresního muzea v Tachově, č. 9, 1-9.

BĚLOHLÁVEK, M. a kol., 1985: Hrady, zámky a tvrze v Čechách, na Moravě a ve Slezsku IV. Západní Čechy. Praha.

BIRNER, Z., 1976: Chodsko a Český les. Praha.

BRUNNER, G., 2007: Eine Typologie von Hufnägeln als Mittel für Datierungen, Mittelalter: Zeitschrift des Schweizerischen Burgenvereins 12, 1-10. Dostupné z http://www.e-periodica.ch.

ČTVERÁK, V. a kol., 2003: Čtverák, V.-Lutovský, M.-Slabina, M.-Smejtek, L., Encyklopedie hradišt v Čechách. Praha.

DURDÍK, T., 2000: Ilustrovaná encyklopedie českých hradů. Praha.

- 2002: Ilustrovaná encyklopedie českých hradů. Dodatky. Praha.

- 2005: Hrady. In: Český les. Př́roda - historie - život (Dudák, V.-Dudáková, A., edd.), 451-466. Praha.

FIŠERA, Z., 2002: Ke stavební podobě středověkých strážnic. In: Dějiny staveb 2002. Sborník př́íspěvků z konference Dějiny staveb 2002, 46-49. Plzeň.

FRÖHLICH, J., 1971: Opevnění z doby hradištní u Kučeře, Výběr z prací členů historického kroužku při Jihočeském muzeu 8, č. 1, 19-20.

- 1973: Kučeř, o. Písek. In: Výzkumy v Čechách 1970, 56-57. Praha.

- 1997: Písecko v zrcadle archeologie. Písek.

FRÖHLICH, J.-MICHÁLEK, J., 1978: Archeologické nemovité památky v okrese Písek. Zprávy Československé společnosti archeologické při Čs. akademii věd. Praha - Nitra - Brno.

HAJŠMAN, J., 2001: Takzvaný Nový hrad u Stráže, Hláska XII, č. 4, 49-54.

HRAŠE, J. K., 1885: Zemské stezky, strážnice a brány v Čechách. Nové Město nad Metují.

HRUBÁ, H.-HRUBÝ, J., 2018: Nový hrad u Stráže (okres Tachov). Keramické nálezy. Plzeň.

CHOC, P., 1967: S mečem i štítem. Praha.

KOČÁROVÁ, R., 2019: Nový Hrad, k. ú. Stráž u Tachova. Zpráva o antrakologické analýze. Kokořov.

KÖFERL, J., 1890: Der politische Bezirk Tachau. Eine Heimatskunde für Haus und Schule unter Mitwirkung der Bezirks-Lehrerschaft. Tachau.

KOŠTIAL, J. Ch., 2016: Nový hrad u Stráže, polní opevnění. Zaměření terénních reliktů. Geodetická a výkresová dokumentace výzkumu pro NPÚ ÚOP v Plzni (technická zpráva). Praha. 
KOUŘIL, P.-ŽÁČEK, R., 1989: Středověké opevnění v moravskoslezských Beskydech - Mittelalterliche Befestigung in den Mährisch-Schlesischen Beskiden, CB 1, 271-275.

KRŮL, M., 2010: Stav výzkumu novověkých opevnění slezsko-uhersko-polské hranice. In: Polní opevnění od třicetileté války do roku 1945. Sborník Národního památkového ústavu, územního odborného pracoviště v Josefově, 8-18. Jaroměř - Josefov.

KŘIVÁNEK, R., 2017: Stráž u Tachova (Nový hrad), okr. Tachov. Závěrečná zpráva o geofyzikálním průzkumu. Praha.

KUČA, K., 2008: Města a městečka v Čechách, na Moravě a ve Slezsku VII. Praha.

LACHMAN, V., 2018: Vyjádření geologa k archeologickému výzkumu - hradiště Stráž z 5. 11. 2018, ulož. v archivu oddělení archeologie NPÚ ÚOP v Plzni.

MATOUŠEK, V., 2006: Třebel. Obraz krajiny s bitvou. Praha.

MATOUŠEK, V.-HRNČIŘÍK, P.-ŠÁMAL, Z., 2018: Rozvadov 1621: Výzkum bojiště třicetileté války. Praha.

MAUR, E., 1970: Panství Planá za války o rakouské dědictví, Sborník Okresního muzea v Tachově, č. 4 , $1-6$.

- 1984: Chodové. Historie a historická tradice. Praha.

MEDUNA, P., 1990: Morphology of field fortifications od the 17th-19th ccenturies, Studies in Post-Medieval Archaeology 1, 75-86.

MINÁTOVÁ, H., 1979: Komunikace na území Českého lesa v letech 1500-1848, Sborník Okresního muzea v Tachově, č. 12, 26-35.

NOVÁČEK, K., 1993: Hlášení Západočeského muzea v Plzni č. j. 364/93.

OHLAVA, R.-SABOL, M., 2018: Nový Hrad u Stráže. Geodetické zaměření sond. Praha.

PLAČEK, M., 1990: Fortifikace ke kontrole a zajištění středověkých komunikací - Fortifikationen zur kontrolle und Sicherung mettelalterlicher Verbindungswege, AH 15, 203-215.

POSTRÁNECKÁ, K.-WASKOVÁ, M., 2008: Změny v lokaci středověké vsi Ostrov na Tachovsku - Änderungen auf der Grabungsstätte des mittelalterlichen Dorfes Ostrov um Tachov, AH 33, 73-83.

PROCHÁZKA, Z., 1984: Stráž, okr. Tachov. In: Výzkumy v Čechách 1980-1981, 118. Praha.

- 1992: Stráž. Stavební a kulturní památky západních Čech č. 12. Domažlice.

- 1995: Stř́ibrsko a Borsko. Historicko-turistický průvodce č. 4. Domažlice.

PROCHÁZKA, Z.-ÚLOVEC, J., 1988: Hrady, zámky a tvrze okresu Tachov. Praha.

- 1991: Hrady, zámky a tvrze okresu Tachov 3. Praha.

ROUBÍK, F., 1938: Silnice v Čechách a jejich vývoj. Praha.

- 1940: Chodské majestáty. Praha.

SEDLÁČEK, A., 1927: Hrady, zámky a tvrze Království českého XV. Praha.

- 1998: Hrady, zámky a tvrze Království českého XIII. Praha (1. vydání 1905).

SOKOL, P., 2011: Šibenice u Přimdy, okres Tachov. Z výsledků systematického povrchového průzkumu šibeničních vrchů západních Čech - Galgen bei Přimda, Kreis Tachov. Aus den Ergebnissen der systematischen Oberflächenuntersuchung der Galgenberge, AZČ 2, 182-188.

- 2014: Archeologie na hradě Přimda - Archaeology at Přimda Castle, Památky západních Čech 4, 53-68.

- 2014a: K podobě, funkční struktuře a původu románského donjonu hradu Přimda - Zur Gestalt, Funktionsstruktur und Herkunft des romanischen Donjon der Burg Přimda. In: Dějiny staveb 2014. Sborník příspěvků z konference Dějiny staveb 2014, 5-22. Plzeň.

- 2015: Výzkum a dokumentace zříceniny hradu Přimda. Aplikace dokumentačních a prospekčních metod v areálu hradní zříceniny - Untersuchung und Dokumentation der Burgruine Přimda. Die Anwendung von Dokumentations- und Prospektionsmethoden im Areal der Burgruine, AH 40, 429-455.

- 2015a: Zř́cenina hradu Přimda - laserová dokumentace a trojrozměrný model donjonu - The ruins of Přimda Castle - laser documentation and a three-dimensional model of the donjon, CB 15, 60-73.

- 2016: Šibenice u Přimdy. Archeologický výzkum objektu se zvláštním symbolickým a sociálním významem - Ein Galgen bei Přimda. Archäologische Ausgrabung eines Objektes von besonderer symbolischer und socialer Bedeutung, AH 41, 501-523.

SOKOL, P.-PREKOP, F., 2013: Nová zjištění na hradě Přimda. Vizuální průzkum a zaměření areálu hradní zrríceniny - New finding at Přimda Castle. Visual Research and focus of the castle ruins, ZPP 73, $448-455$.

SVOBODA, L. a kol., 1998: Encyklopedie českých tvrzí. I. díl. Praha.

ŠÍDA, P., 2005: Strážné systémy, ASČ 9, 589-603.

ŠIROKÝ, R.-NOVÁČEK, K., 1998: K počátkům Norimberské cesty na Tachovsku - Zu den Anfängen des Nürbergerweges auf dem Gebiet von Tachov, AH 23, 59-71.

TUREK, R., 1970: Stavební ráz středověkých hradů na Tachovsku, Sborník Okresního muzea v Tachově, č. $5,1-15$. 
ULRICHOVÁ, E., 2010: Novověké vojenské tábory na Jičínsku, in: Polní opevnění od třicetileté války do roku 1945. In: Sborník Národního památkového ústavu, územního odborného pracoviště v Josefově, 23-32. Jaroměř - Josefov.

VÁVRA, I., 1973: Řezenská a Norimberská cesta, HG 11, 31-100.

WALDHAUSER, J., 1992: Problém identifikace keltských čtyřúhelníkových valů (Viereckschanzen) v Čechách - Problem der Identifikation der keltischen Viereckschanzen in Böhmen, AR XLIV, 548-559.

ŽEMLIČKA, J., 1997: Čechy v době knížecí. Praha.

\section{Internetové zdroje}

Analýza výškopisu. Dostupné z: https://ags.cuzk.cz/dmr/\#, cit. 6. 3. 2019.

Archivní mapy. Dostupné z: https://archivnimapy.cuzk.cz/uazk/pohledy/archiv.html, cit. 20. 1. 2016.

Letecká mapa Čech a Moravy z roku 1953. Dostupné z: https://kontaminace.cenia.cz/, cit. 12. 4. 2019.

Památkový katalog. Dostupné z: https://pamatkovykatalog.cz/?presenter=ElementsResults\&action=element\&element=18657003, nebo https://pamatkovykatalog.cz?element=18657003\&action=element\&presenter=ElementsResults, cit. 6. 3. 2019 .

\section{Zusammenfassung}

\section{Die Befestigung Nový hrad (Schlössl) bei Stráž (Bezirk Tachov). Eine landesherrliche Wach- und Zollstation von der Wende des 12. und 13. Jahrhunderts}

Zwischen Stráž und Přimda befindet sich eine mächtige Erdbefestigung, deren Ursprung und Zweck bislang nicht geklärt wurden. Die spätestens ab dem letzten Viertel des 16. Jahrhunderts als Schlössl bezeichnete, in einem flachen Gelände liegende Befestigung mit einem quadratischem Grundriss von $82 \times 83 \mathrm{~m}$ besteht aus einem Innenwall, einem V-förmigem Graben und einem die $27 \times 27 \mathrm{~m}$ große Innenfläche umgebenden Außenwall. Die Relikte wurden bisher als spätmittelalterlicher Hof, als Übergangsburg, als frühmittelalterlicher Burgwall oder als latènezeitliche Viereckschanzen interpretiert. Die Situation gestaltet sich durch ältere Funde frühmittelalterlicher Keramik, durch die Lage und die markante, sehr gut erhaltene und für die aufgeführten Fundstellenarten atypische Form des Reliktes noch komplizierter.

Neue Erkenntnisse konnten durch eine kürzlich erfolgte Untersuchung und Dokumentation sowie durch die Heranziehung einer Detektorprospektion mit anschließender Überprüfung anhand von archäologischen Sondierungsgrabungen gewonnen werden. Die Grabungen wurden in den Jahren 2016-2019 im Rahmen der forschungswissenschaftlichen Tätigkeit der Pilsener Arbeitsstelle des Nationalen Denkmalinstituts durchgeführt. Der vorliegende Beitrag gibt Auskunft über die Untersuchung des Objektes, über die Datierung und anschließende Interpretation der atypischen Fundstelle. Obwohl die Befestigung bereits ab Ende des 19. Jahrhunderts in der Fachliteratur bekannt ist, sind die bisherigen Interpretationen sehr unsicher und uneinheitlich. Bei der Grabung entdeckte man eine Kollektion an Bruchstücken von Küchen- und Tafelkeramik sowie von Blattkacheln, eine Kollektion an Metallgegenständen mit Hufeisennägeln, normalen Nägeln, Hufeisenfragmenten, Tüllen, Werkzeugen, Beschlägen, einer Schnalle und vor allem zwei Sporen mit pyramidenförmigem Dorn und einem Steigbügelpaar. Freigelegt wurde ein Teil einer verbrannten Holzkonstruktion, eine Bebauung aus Stein wurde jedoch nicht nachgewiesen.

Hinsichtlich der bemerkenswerten Übereinstimmung zwischen der Datierung der Keramik- und Metallgegenstände (Hufeisennägel, Hufeisen, Sporen, Steigbügel) und der dendrochronologischen Datierung sowie Radiokarbondatierung der Holzproben, die von der verbrannten Konstruktion auf der Innenfläche, von Wallelementen und aus der Grabenverfüllung genommen wurden, kann über die Existenz des Objektes im Intervall zweite Hälfte 12. bis erste Hälfte 13. Jahrhundert kein Zweifel bestehen. Die Entstehung des Objektes kann man 
höchstwahrscheinlich an das Ende des 12. Jahrhunderts legen, seinen Untergang (wahrscheinlich durch einen Brand) dann in das zweite Viertel des 13. Jahrhunderts. Eine jüngere Nutzung des Objektes oder Instandsetzungen wurden nicht nachgewiesen, im Hinblick auf den Charakter der Keramikfunde bleibt jedoch die Möglichkeit, dass das Objekt länger existierte oder auch nach seinem möglichen Untergang noch genutzt wurde (erste Hälfte 14. Jahrhundert?).

Die charakteristischen Züge des Objektes, wie die ausgeprägte Mächtigkeit und Regelmäßigkeit der Befestigung, der verteidigungsmäßige, militärische Charakter, aber auch die relativ kleineren Abmessungen, das Fehlen einer Bebauung aus Stein und vor allem die Anlegung des Objektes in Muldenlage bereiteten bisher zusammen mit der vorherigen Datierung der Keramikfunde beträchtliche Interpretationsprobleme, und bei dem Bemühen, die Grundtypen von befestigten - in der Regel mittelalterlicher - Fundstellen heranzuziehen, erwies sich das Schlössl als ein völlig atypisches Objekt.

Außer den eigentlichen archäologischen Funden und ihrer Datierung hat sich der Verlauf eines heute bereits verschwundenen Weges, bei dem es sich um einen von zwei Zweigen des später Nürnberger Straße genannten Landespfades handelte, für die Fundstelle als essentiell erwiesen. Die Trasse dieses spätestens in der ersten Hälfte des 12. Jahrhunderts entstandenen Přimdaschen Zweigs führte in dichter Nähe des Schlössls vorbei, das sich in strategischer Lage zu ihm befand (unmittelbare Kontrolle des betreffenden Wegabschnittes, Überblick über seinen Verlauf in Richtung Přimda, Sichtkontakt mit der Burg Přimda). Aufgrund der oben erwähnten „atypischen“" Merkmale, der speziellen Lage, des Bezugs zu einem wichtigen Verkehrsweg in der Nähe der Landesgrenze sowie der archäologischen Funde und deren Datierung betrachten wir das Schlössl bei Stráž als Station an dem Landespfad (Wach- oder Zollstation, wahrscheinlich mit beiden Funktionen), die im Interesse des Landesherrn als Stützpunkt in einem strategischen Abschnitt des Landespfades errichtet wurde. Wenn man die Existenz und die Vorstellung eines Wachdienstes der Choden im betreffenden Zeitraum nicht in Frage stellt, dann ist das Schlössl mit hoher Wahrscheinlichkeit gleichzeitig ein konkretes, mit dieser Bevölkerungsgruppe im südwestlichen böhmischen Grenzgebiet verbundenes Objekt.

Für eine Interpretation des Zwecks des Schlössls kann man in einigen bislang nicht eindeutig interpretierten Objekten aus dem annähernd gleichen Zeitraum Analogien finden. Es ist wahrscheinlich, dass solche Fundstellen eine Überprüfung und eventuelle Umbewertung verdient haben, deren Interpretation aus Sicht der bisher traditionell zugrunde gelegten Typologie von befestigten Objekten problematisch war, was auch solche Objekte umfasst, bei denen mittelalterliche Funde als Beleg für eine sekundäre Nutzung angesehen wurden.

Der vorliegende Beitrag ist ein Output des Forschungszieles der Archäologie (Teilziel Geländeidentifizierung und Dokumentation ausgewählter archäologischer Fundstellen und übergangener archäologischer Denkmäler in der Landschaft unter Zuhilfenahme neuer Dokumentationsmethoden) und wurde vom institutionellen Förderprogramm des Ministeriums für Kultur für langfristige Entwicklung der Forschungsorganisation Nationales Denkmalinstitut finanziert.

Mgr. Petr Sokol, Národní památkový ústav, územní odborné pracoviště v Plzni, Prešovská 7, 30637 Plzeň, Česká republika,sokol.petr@npu.cz

PhDr. Filip Kasl, Národní památkový ústav, územní odborné pracoviště v Plzni, Prešovská 7, 30637 Plzeň, Česká republika, kasl.filip@npu.cz 
